$$
\text { for }
$$

\title{
Isolation of a Ge(I) Diradicaloid and Dihydrogen Splitting
}

Mahendra K. Sharma, Falk Ebeler, Timo Glodde, Beate Neumann, Hans-Georg Stammler, and Rajendra S. Ghadwal*

Molecular Inorganic Chemistry and Catalysis, Inorganic and Structural Chemistry, Center for Molecular Materials,

Faculty of Chemistry, Universität Bielefeld, Universitätsstrasse 25, D-33615, Bielefeld, Germany *Email: rghadwal@uni-bielefeld.de

Fax: +49521 106 6026; Tel: +495211066167 
Table of Contents $\quad$ S2

Experimental Section ...................................................................................................................

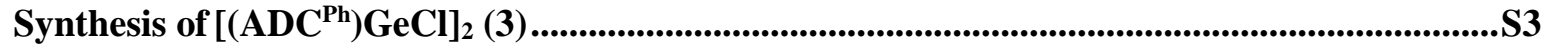

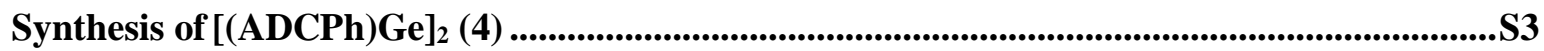

Reaction of 4 with Dihydrogen to 5 ...................................................................................................S4

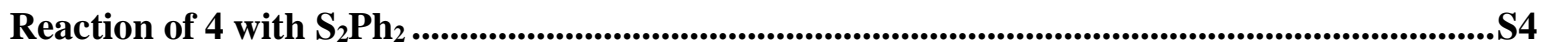

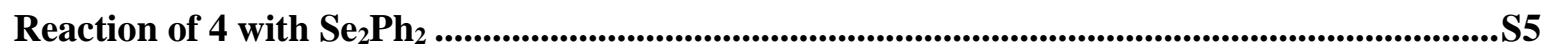

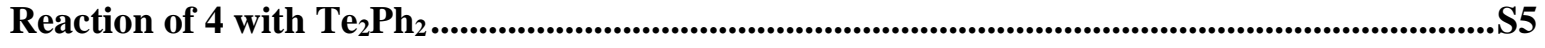

Plots of the NMR Spectra ...........................................................................................................57

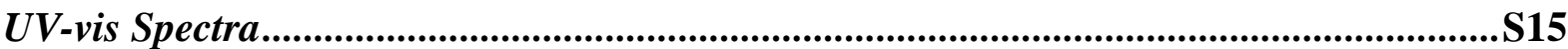

Crystallographic Details .......................................................................................................516

Computational Details ............................................................................................................S21

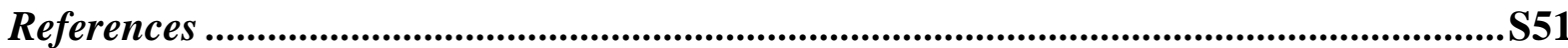




\section{Experimental Section}

All experiments and manipulations were carried out under an inert gas $\left(\mathrm{Ar}\right.$ or $\left.\mathrm{N}_{2}\right)$ atmosphere using standard Schlenk techniques or an MBraun LABmaster Pro glovebox. THF, toluene, benzene, and $n$ hexane were dried by refluxing over $\mathrm{NaK}$, distilled prior to use, and stored over $3 \AA$ molecular sieve. Starting material $\left(\mathrm{IPr}^{\mathrm{Ph}}\right) \mathrm{Cl}(\mathbf{1})$ was obtained through the $\mathrm{Cl}^{-}$ion exchange from its bromide salt $\left(\mathrm{IPr}^{\mathrm{Ph}}\right.$ ) $\mathrm{Br}^{[1]}$ (DMAP) $\mathrm{GeCl}_{2}$ was prepared using the literature method. ${ }^{[2]} \mathrm{S}_{2} \mathrm{Ph}_{2}, \mathrm{Se}_{2} \mathrm{Ph}_{2}$, and $\mathrm{Te}_{2} \mathrm{Ph}_{2}$ (Sigma) were used as supplied. NMR spectra were recorded using a Bruker Avance III 500HD NMR spectrometer. Chemical shifts are given in $\delta$ ppm and referenced to the solvent residual peak(s). ${ }^{[3]}$ Melting points were measured using a Büchi B-545 melting point apparatus. UV-visible spectra were recorded at a Thermo Fisher Evolution 300 spectrophotometer.

\section{Synthesis of $\left[\left(\mathrm{ADC}^{\mathrm{Ph}}\right) \mathrm{GeCl}\right]_{2}(3)$}

To a Schlenk flask containing a THF suspension of $\left(\operatorname{IPr}^{\mathrm{Ph}}\right) \mathrm{Cl}(\mathbf{1})(5.0 \mathrm{~g}, 9.98 \mathrm{mmol})$ was added $n$-BuLi $(2.5 \mathrm{M}, 8.2 \mathrm{~mL}, 20.4 \mathrm{mmol})$ at $-60{ }^{\circ} \mathrm{C}$. The resulting reaction mixture was brought to room temperature and stirred for additional 30 minutes to get a clear light brown solution of $\mathrm{Li}\left(\mathrm{ADC}^{\mathrm{Ph}}\right)$ (2). ${ }^{[4]}$ The resulting solution was transferred to a precooled $\left(-40{ }^{\circ} \mathrm{C}\right)$ THF suspension of (DMAP) $\mathrm{GeCl}_{2}$ (2.65 g, $9.98 \mathrm{mmol}$ ). The reaction mixture was stirred overnight at room temperature. All volatiles were removed in vaccuo to obtain a light yellow residue (DMAP was removed under vacuum at $60{ }^{\circ} \mathrm{C}$ ). The residue was extracted with fluorobenzene, dried, washed with $50 \mathrm{~mL}$ toluene, and re-dried to get 3 as a colorless crystalline powder. Yield: $75 \%, 4.28$ g. M.p.: $171{ }^{\circ} \mathrm{C}$ (dec.). X-ray quality single crystals were grown by storing a $\mathrm{THF} / \mathrm{Et}_{2} \mathrm{O}(80: 20)$ solution of $\mathbf{3}$ at $-40{ }^{\circ} \mathrm{C}$ for three days. Elemental analysis (\%), calcd for $\mathrm{C}_{66} \mathrm{H}_{78} \mathrm{Cl}_{2} \mathrm{Ge}_{2} \mathrm{~N}_{4}$ (1143.54) 3: C, 69.32; H, 6.88; N, 4.90; found: C, 69.67; H, 6.97; N, 5.07. ${ }^{1} \mathrm{H}$ NMR (500 MHz, $\left.\mathrm{C}_{6} \mathrm{D}_{6}, 298 \mathrm{~K}\right): \delta=7.19$ (m, 4H, $\left.m-\mathrm{C}_{6} H_{3}\right), 6.99$ $\left(\mathrm{m}, 2 \mathrm{H}, p-\mathrm{C}_{6} H_{3}\right), 6.96\left(\mathrm{~d}, J=8.2 \mathrm{~Hz}, 2 \mathrm{H}, \mathrm{C}_{6} H_{5}\right), 6.57\left(\mathrm{q}, J=6.5 \mathrm{~Hz}, 3 \mathrm{H}, \mathrm{C}_{6} H_{5}\right), 3.43(\mathrm{~m}, 2 \mathrm{H}$, $\left.\mathrm{CH}\left(\mathrm{CH}_{3}\right)_{2}\right), 3.08\left(\mathrm{~m}, 2 \mathrm{H}, \mathrm{CH}\left(\mathrm{CH}_{3}\right)_{2}\right), 1.55\left(\mathrm{~d}, J=6.7 \mathrm{~Hz}, 6 \mathrm{H}, \mathrm{CH}\left(\mathrm{CH}_{3}\right)_{2}\right), 1.49$ (d, $J=6.6 \mathrm{~Hz}, 6 \mathrm{H}$, $\left.\mathrm{CH}\left(\mathrm{CH}_{3}\right)_{2}\right), 1.34\left(\mathrm{~d}, J=6.8 \mathrm{~Hz}, 6 \mathrm{H}, \mathrm{CH}\left(\mathrm{CH}_{3}\right)_{2}\right), 0.34\left(\mathrm{~d}, J=6.8 \mathrm{~Hz}, 6 \mathrm{H}, \mathrm{CH}\left(\mathrm{CH}_{3}\right)_{2}\right) \mathrm{ppm}$. ${ }^{13} \mathrm{C}\left\{{ }^{1} \mathrm{H}\right\}$ NMR $\left(125 \mathrm{MHz}, \mathrm{C}_{6} \mathrm{D}_{6}, 298 \mathrm{~K}\right): \delta=162.0(\mathrm{NCCN}) ; 146.2,146.1,142.9,134.4\left(C_{6} \mathrm{H}_{3}\right)$; 130.7, 129.7, 125.5, $124.4\left(\mathrm{C}_{6} \mathrm{H}_{5}\right)$; 29.6, $28.8\left(\mathrm{CH}\left(\mathrm{CH}_{3}\right)_{2}, 25.9,25.5,23.6\left(\mathrm{CH}_{3}\right)\right.$.

\section{Synthesis of $[(\mathrm{ADCPh}) \mathrm{Ge}]_{2}(4)$}

To a $250 \mathrm{~mL}$ Schlenk flask containing a THF solution of $\mathbf{3}(1.0 \mathrm{~g}, 0.87 \mathrm{mmol})$ was added $\mathrm{KC}_{8}$ $(0.3 \mathrm{~g}, 2.26 \mathrm{mmol})$ in one portion at $-60{ }^{\circ} \mathrm{C}$. The resulting reaction mixture was stirred at room temperature for $12 \mathrm{~h}$ and then filtered through a G4 frit. Removal of the volatiles from the filtrate gave a pure sample of $\mathbf{4}$ as a red solid. X-ray quality single crystals were grown by a slow diffusion of $n$-hexane into a saturated THF solution of $\mathbf{4}$ at room temperature. Yield: 
98\%, 0.92 g. M.p.: $153{ }^{\circ} \mathrm{C}$ (dec.). Elemental analysis (\%), calcd for $\mathrm{C}_{66} \mathrm{H}_{78} \mathrm{Ge}_{2} \mathrm{~N}_{4}(1072.63)$ 4: C, 73.90; H, 7.33; N, 5.22; found: C, 74.16; H, 7.67; N, 5.37. ${ }^{1} \mathrm{H}$ NMR (500 MHz, THF-d8, $298 \mathrm{~K}): \delta=7.36\left(\mathrm{t}, J=7.8 \mathrm{~Hz}, 2 \mathrm{H}, p-\mathrm{C}_{6} H_{3}\right), 7.21\left(\mathrm{~d}, J=7.8 \mathrm{~Hz}, 4 \mathrm{H}, m-\mathrm{C}_{6} H_{3}\right), 7.17(\mathrm{~d}, J=$ $\left.7.5 \mathrm{~Hz}, 2 \mathrm{H}, o-\mathrm{C}_{6} H_{5}\right), 7.13\left(\mathrm{t}, J=7.4 \mathrm{~Hz}, 1 \mathrm{H}, p-\mathrm{C}_{6} H_{5}\right), 7.03$ (t, $\left.J=7.9 \mathrm{~Hz}, 2 \mathrm{H}, m-\mathrm{C}_{6} H_{5}\right), 2.78$ $\left(\mathrm{m}, 4 \mathrm{H}, \mathrm{CH}\left(\mathrm{CH}_{3}\right)_{2}\right), 1.21\left(\mathrm{~d}, J=6.7 \mathrm{~Hz}, 12 \mathrm{H}, \mathrm{CH}\left(\mathrm{CH}_{3}\right)_{2}\right), 0.91(\mathrm{~d}, J=6.9 \mathrm{~Hz}, 12 \mathrm{H}$, $\left.\mathrm{CH}\left(\mathrm{CH}_{3}\right)_{2}\right)$ ppm. ${ }^{13} \mathrm{C}\left\{{ }^{1} \mathrm{H}\right\} \mathrm{NMR}\left(125 \mathrm{MHz}, \mathrm{THF}-d_{8}, 298 \mathrm{~K}\right): \delta=182.9(\mathrm{NCCN}) ; 147.3$,

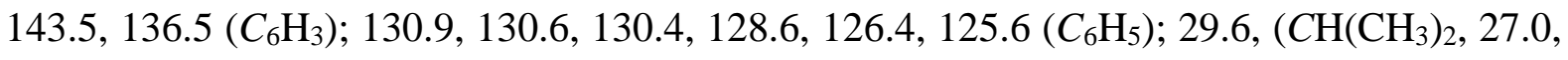
$24.0\left(\mathrm{CH}_{3}\right)$.

\section{Reaction of 4 with Dihydrogen to 5}

A $\mathrm{C}_{6} \mathrm{D}_{6}$ solution of $4(20 \mathrm{mg})$ in a $J$-young NMR tube was exposed to $\mathrm{H}_{2}(1 \mathrm{~atm})$ at $\mathrm{rt}$. The red-brown solution of $\mathbf{4}$ immediately turned wine red. The ${ }^{1} \mathrm{H}$ NMR spectrum after exposure to $\mathrm{H}_{2}$ indicates quantitative conversion of 4 (Figure S5) into 5 (Figure S6).

Large-scale synthesis of 5: A $20 \mathrm{~mL}$ toluene solution of 4 (0.52 g, $0.48 \mathrm{mmol})$ was exposed to $\mathrm{H}_{2}$ gas $(1 \mathrm{~atm})$ at $\mathrm{rt}$ and stirred for $2 \mathrm{~h}$. The resulting wine-red solution was concentrated to $10 \mathrm{~mL}$, combined with $10 \mathrm{~mL} n$-hexane, and stored at $-30{ }^{\circ} \mathrm{C}$ for 3 days. Compound 5 was isolated as an orange-red solid in $47 \%$ yield $(0.24 \mathrm{~g})$ after filtration and drying under vacuum. Elemental analysis (\%), calcd for $\mathrm{C}_{66} \mathrm{H}_{80} \mathrm{Ge}_{2} \mathrm{~N}_{4}$ (1074.65) 5: C, 73.77; H, 7.50; N, 5.21; found: C, 73.22; H, 7.27; N, 4.79. ${ }^{1} \mathrm{H}$ NMR (500 MHz, $\left.\mathrm{C}_{6} \mathrm{D}_{6}, 298 \mathrm{~K}\right): \delta=7.19$ (t, 2H, J=7.7 $\left.\mathrm{Hz}, p-\mathrm{C}_{6} H_{3}\right), 7.07$ (d, 4H, J = 7.4 Hz, $\left.m-\mathrm{C}_{6} H_{3}\right), 6.95$ (br, 2H, $\left.\mathrm{C}_{6} H_{5}\right), 6.55$ (br, 3H, $\left.\mathrm{C}_{6} H_{5}\right), 5.01$ (s, $1 \mathrm{H}, \mathrm{Ge} H), 3.32\left(\mathrm{~m}, 2 \mathrm{H}, J=6.7 \mathrm{~Hz}, \mathrm{CH}\left(\mathrm{CH}_{3}\right)_{2}\right), 3.25\left(\mathrm{~m}, 2 \mathrm{H}, J=6.7 \mathrm{~Hz}, \mathrm{CH}\left(\mathrm{CH}_{3}\right)_{2}\right), 1.52$ $\left(\mathrm{d}, J=6.6 \mathrm{~Hz}, 6 \mathrm{H}, \mathrm{CH}\left(\mathrm{CH}_{3}\right)_{2}\right), 1.42\left(\mathrm{~d}, J=6.6 \mathrm{~Hz}, 6 \mathrm{H}, \mathrm{CH}\left(\mathrm{CH}_{3}\right)_{2}\right), 0.89(\mathrm{~m}, J=6.8 \mathrm{~Hz}, 12 \mathrm{H}$, $\left.\mathrm{CH}\left(\mathrm{CH}_{3}\right)_{2}\right)$ ppm. ${ }^{13} \mathrm{C}\left\{{ }^{1} \mathrm{H}\right\} \mathrm{NMR}\left(125 \mathrm{MHz}, \mathrm{THF}-d_{8}, 298 \mathrm{~K}\right): \delta=157.8,156.83(\mathrm{NCCN})$; 146.2 , 145.7, 144.4, 136.2, 130.8, 129.7, 129.4, 128.9, 128.4, 128.3, 126.1, 125.6, 125.5 $\left(\mathrm{C}_{6} \mathrm{H}_{3}, \mathrm{C}_{6} \mathrm{H}_{5}\right) ; 29.5,29.1\left(\mathrm{CH}\left(\mathrm{CH}_{3}\right)_{2}, 26.4,25.8,23.9,23.8\left(\mathrm{CH}_{3}\right) \mathrm{ppm}\right.$.

\section{Reaction of $\mathbf{4}$ with $\mathbf{S}_{2} \mathbf{P h}_{2}$}

To a solid mixture of 4 (150 mg, $0.14 \mathrm{mmol})$ and $\mathrm{S}_{2} \mathrm{Ph}_{2}(25 \mathrm{mg}, 0.14 \mathrm{mmol})$ was added 10 $\mathrm{mL}$ THF at room temperature and stirred for $5 \mathrm{~min}$. The volatiles from the resulting solution were removed and the residue was washed with $n$-hexane $(2 \mathrm{~mL})$ and dried to get $\mathbf{6 - S}$ as a yellow solid. Yield: 91\%, $165 \mathrm{mg}$. M.p. $172{ }^{\circ} \mathrm{C}$ (dec.). X-ray quality single crystals were grown at room temperature by a slow diffusion of $n$-hexane into a saturated benzene solution of 6-S. Elemental analysis (\%), calcd for $\mathrm{C}_{78} \mathrm{H}_{88} \mathrm{Ge}_{2} \mathrm{~N}_{4} \mathrm{~S}_{2}$ (1290.97) 6-S: C, 72.57; H, 6.87; N, 4.34; found: C, 72.79; H, 6.97; N, 4.45. ${ }^{1} \mathrm{H}$ NMR (500 MHz, THF- $\left.d_{8}, 298 \mathrm{~K}\right): \delta=7.40(\mathrm{t}, J=$ 
$\left.7.8 \mathrm{~Hz}, 2 \mathrm{H}, p-\mathrm{C}_{6} H_{3}\right), 7.26\left(\mathrm{~d}, J=7.8 \mathrm{~Hz}, 2 \mathrm{H}, m-\mathrm{C}_{6} H_{3}\right), 7.09\left(\mathrm{t}, J=6.7 \mathrm{~Hz}, 3 \mathrm{H}, \mathrm{C}_{6} H_{5}\right), 6.94$ $\left(\mathrm{d}, J=8.1 \mathrm{~Hz}, 2 \mathrm{H}, m-\mathrm{C}_{6} H_{3}\right), 6.75\left(\mathrm{dd}, J=7.4,5.6 \mathrm{~Hz}, 4 \mathrm{H}, \mathrm{C}_{6} H_{5}\right), 6.64(\mathrm{t}, J=7.3 \mathrm{~Hz}, 2 \mathrm{H}$, $\left.\mathrm{C}_{6} H_{5}\right), 6.58\left(\mathrm{t}, J=7.3 \mathrm{~Hz}, 1 \mathrm{H}, \mathrm{C}_{6} H_{5}\right), 3.47\left(\mathrm{~m}, 2 \mathrm{H}, \mathrm{CH}\left(\mathrm{CH}_{3}\right)_{2}\right), 2.64\left(\mathrm{~m}, 2 \mathrm{H}, \mathrm{CH}\left(\mathrm{CH}_{3}\right)_{2}\right), 1.31$ $\left(\mathrm{d}, J=6.7 \mathrm{~Hz}, 6 \mathrm{H}, \mathrm{CH}\left(\mathrm{CH}_{3}\right)_{2}\right), 0.86\left(\mathrm{~d}, J=6.5 \mathrm{~Hz}, 6 \mathrm{H}, \mathrm{CH}\left(\mathrm{CH}_{3}\right)_{2}\right), 0.75(\mathrm{~d}, J=6.8 \mathrm{~Hz}, 6 \mathrm{H}$, $\left.\mathrm{CH}\left(\mathrm{CH}_{3}\right)_{2}\right), 0.61\left(\mathrm{~d}, J=6.8 \mathrm{~Hz}, 6 \mathrm{H}, \mathrm{CH}\left(\mathrm{CH}_{3}\right)_{2}\right) \mathrm{ppm} .{ }^{13} \mathrm{C}\left\{{ }^{1} \mathrm{H}\right\}$ NMR $\left(125 \mathrm{MHz}, \mathrm{THF}-d_{8}\right.$, $298 \mathrm{~K}): \delta=160.4(\mathrm{NCCN}) ; 147.9,147.2,146.0,145.2,135.4,131.2135 .1\left(C_{6} \mathrm{H}_{3}\right) ; 130.6$,

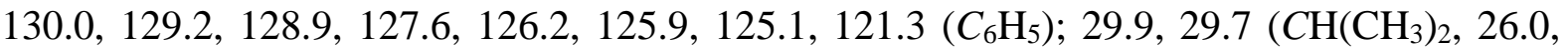
24.6, 24.3, $23.6\left(\mathrm{CH}_{3}\right)$.

\section{Reaction of 4 with $\mathrm{Se}_{2} \mathrm{Ph}_{2}$}

To a THF (10 mL) solution of 4 (150 mg, $0.14 \mathrm{mmol})$ was transferred a THF (1 mL) solution of $\mathrm{Se}_{2} \mathrm{Ph}_{2}$ (44 mg, $\left.0.14 \mathrm{mmol}\right)$ at $\mathrm{rt}$ and stirred for $5 \mathrm{~min}$. The volatiles were then removed and the residue was washed with $n$-hexane $(2 \mathrm{~mL})$ and dried to obtain $\mathbf{6}$-Se as a yellow solid. Yield: $93 \%, 180$ mg. M.p. $165{ }^{\circ} \mathrm{C}$ (dec.). Elemental analysis (\%), calcd for $\mathrm{C}_{78} \mathrm{H}_{88} \mathrm{Ge}_{2} \mathrm{~N}_{4} \mathrm{Se}_{2}$ (1384.76) 6-Se: C, 67.65; H, 6.41; N, 4.05; found: C, 67.83; H, 6.67; N, 4.17. ${ }^{1} \mathrm{H}$ NMR $\left(500 \mathrm{MHz}, \mathrm{THF}-d_{8}, 298 \mathrm{~K}\right): \delta=7.42\left(\mathrm{t}, J=7.7 \mathrm{~Hz}, 2 \mathrm{H}, p-\mathrm{C}_{6} H_{3}\right), 7.27(\mathrm{~d}, J=7.7 \mathrm{~Hz}, 2 \mathrm{H}, m-$ $\left.\mathrm{C}_{6} H_{3}\right), 7.10\left(\mathrm{~d}, J=7.8 \mathrm{~Hz}, 3 \mathrm{H}, \mathrm{C}_{6} H_{5}\right), 6.95\left(\mathrm{t}, J=7.9 \mathrm{~Hz}, 2 \mathrm{H}, m-\mathrm{C}_{6} H_{3}\right), 6.90(\mathrm{t}, J=7.6 \mathrm{~Hz}$, $\left.2 \mathrm{H}, \mathrm{C}_{6} H_{5}\right), 6.75\left(\mathrm{~d}, J=8.3 \mathrm{~Hz}, 2 \mathrm{H}, \mathrm{C}_{6} H_{5}\right), 6.68\left(\mathrm{t}, J=7.1 \mathrm{~Hz}, 1 \mathrm{H}, \mathrm{C}_{6} H_{5}\right), 6.64(\mathrm{t}, J=7.2 \mathrm{~Hz}$, $\left.2 \mathrm{H}, \mathrm{C}_{6} H_{5}\right), 3.58\left(\mathrm{~m}, 2 \mathrm{H}, \mathrm{CH}\left(\mathrm{CH}_{3}\right)_{2}\right), 2.62\left(\mathrm{~m}, 2 \mathrm{H}, \mathrm{CH}\left(\mathrm{CH}_{3}\right)_{2}\right), 1.31(\mathrm{~d}, J=6.7 \mathrm{~Hz}, 6 \mathrm{H}$, $\left.\mathrm{CH}\left(\mathrm{CH}_{3}\right)_{2}\right), 0.88\left(\mathrm{~d}, J=6.5 \mathrm{~Hz}, 6 \mathrm{H}, \mathrm{CH}\left(\mathrm{CH}_{3}\right)_{2}\right), 0.75\left(\mathrm{~d}, J=6.8 \mathrm{~Hz}, 6 \mathrm{H}, \mathrm{CH}\left(\mathrm{CH}_{3}\right)_{2}\right), 0.64(\mathrm{~d}$, $\left.J=6.8 \mathrm{~Hz}, 6 \mathrm{H}, \mathrm{CH}\left(\mathrm{CH}_{3}\right)_{2}\right)$ ppm. ${ }^{13} \mathrm{C}\left\{{ }^{1} \mathrm{H}\right\} \mathrm{NMR}\left(125 \mathrm{MHz}, \mathrm{C}_{6} \mathrm{D}_{6}, 298 \mathrm{~K}\right): \delta=160.7$ $(\mathrm{NCCN}) ; 147.2,146.0,145.2,140.9,135.5,133.4\left(C_{6} \mathrm{H}_{3}\right) ; 131.2,130.6,130.0,129.2,128.8$, 127.9, 126.3, 125.9, 125.2, $122.5\left(C_{6} \mathrm{H}_{5}\right)$; 30.0, $29.7\left(\mathrm{CH}\left(\mathrm{CH}_{3}\right)_{2}, 26.2,24.9,24.5,23.5\left(\mathrm{CH}_{3}\right)\right.$. ${ }^{77} \mathrm{Se}\left\{{ }^{1} \mathrm{H}\right\}$ NMR (95 MHz, THF- $\left.d_{8}, 298 \mathrm{~K}\right): \delta=246.6(\mathrm{SePh})$.

\section{Reaction of 4 with $\mathrm{Te}_{2} \mathrm{Ph}_{2}$}

To a THF (10 mL) solution of $4(150 \mathrm{mg}, 0.14 \mathrm{mmol})$ was added a THF (1 mL) solution of $\mathrm{Te}_{2} \mathrm{Ph}_{2}(57 \mathrm{mg}, 0.14 \mathrm{mmol})$ at $\mathrm{rt}$ and stirred for $5 \mathrm{~min}$. The volatiles were then removed and the residue was washed with $n$-hexane $(2 \mathrm{~mL})$ and dried to afford 6-Te as a yellow solid. Yield: 95\%, 197 mg. M.p. $167{ }^{\circ} \mathrm{C}$ (dec.). X-ray quality single crystals were grown at room temperature by a slow diffusion of $n$-hexane into a saturated benzene solution of 6-Te. Elemental analysis (\%), calcd for $\mathrm{C}_{78} \mathrm{H}_{88} \mathrm{Ge}_{2} \mathrm{~N}_{4} \mathrm{Te}_{2}$ (1482.04) 6-Te: C, 63.21; H, 5.98; N, 3.78; found: C, 63.47; H, 6.17; N, 3.97. ${ }^{1} \mathrm{H}$ NMR (500 MHz, THF- $\left.d_{8}, 298 \mathrm{~K}\right): \delta=7.43$ (t, $J=$ $\left.7.8 \mathrm{~Hz}, 2 \mathrm{H}, p-\mathrm{C}_{6} H_{3}\right), 7.29\left(\mathrm{~d}, J=7.8 \mathrm{~Hz}, 2 \mathrm{H}, m-\mathrm{C}_{6} H_{3}\right), 7.12\left(\mathrm{~d}, J=7.9 \mathrm{~Hz}, 3 \mathrm{H}, \mathrm{C}_{6} H_{5}\right), 7.07$ 
(d, $\left.J=7.9 \mathrm{~Hz}, 2 \mathrm{H}, m-\mathrm{C}_{6} H_{3}\right), 6.93\left(\mathrm{t}, J=8.0 \mathrm{~Hz}, 2 \mathrm{H}, \mathrm{C}_{6} H_{5}\right), 6.74\left(\mathrm{t}, J=7.3 \mathrm{~Hz}, 3 \mathrm{H}, \mathrm{C}_{6} H_{5}\right)$, $6.58\left(\mathrm{t}, J=7.5 \mathrm{~Hz}, 2 \mathrm{H}, \mathrm{C}_{6} H_{5}\right), 3.65\left(\mathrm{~m}, 2 \mathrm{H}, \mathrm{CH}\left(\mathrm{CH}_{3}\right)_{2}\right), 2.60\left(\mathrm{~m}, 2 \mathrm{H}, \mathrm{CH}\left(\mathrm{CH}_{3}\right)_{2}\right), 1.32(\mathrm{~d}, J=$ $\left.6.7 \mathrm{~Hz}, 6 \mathrm{H}, \mathrm{CH}\left(\mathrm{CH}_{3}\right)_{2}\right), 0.98\left(\mathrm{~d}, J=6.5 \mathrm{~Hz}, 6 \mathrm{H}, \mathrm{CH}\left(\mathrm{CH}_{3}\right)_{2}\right), 0.75(\mathrm{~d}, J=6.8 \mathrm{~Hz}, 6 \mathrm{H}$, $\left.\mathrm{CH}\left(\mathrm{CH}_{3}\right)_{2}\right), 0.67\left(\mathrm{~d}, J=6.8 \mathrm{~Hz}, 6 \mathrm{H}, \mathrm{CH}\left(\mathrm{CH}_{3}\right)_{2}\right) \mathrm{ppm} .{ }^{13} \mathrm{C}\left\{{ }^{1} \mathrm{H}\right\} \mathrm{NMR}\left(125 \mathrm{MHz}, \mathrm{THF}-d_{8}\right.$, $298 \mathrm{~K}): \delta=160.7(\mathrm{NCCN}) ; 147.3,146.0,145.5,138.1,135.5\left(C_{6} \mathrm{H}_{3}\right) ; 131.3,130.6,129.9$,

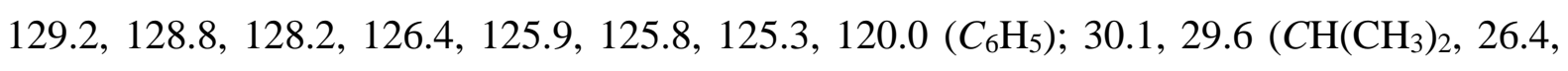
25.8, 24.8, $23.5\left(\mathrm{CH}_{3}\right) .{ }^{125} \mathrm{Te}\left\{{ }^{1} \mathrm{H}\right\} \mathrm{NMR}\left(158 \mathrm{MHz}, \mathrm{THF}-d_{8}, 298 \mathrm{~K}\right): \delta=215.3(\mathrm{TePh})$. 


\section{Plots of the NMR Spectra}

ํํํ유 욱 N

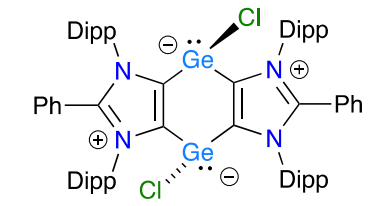

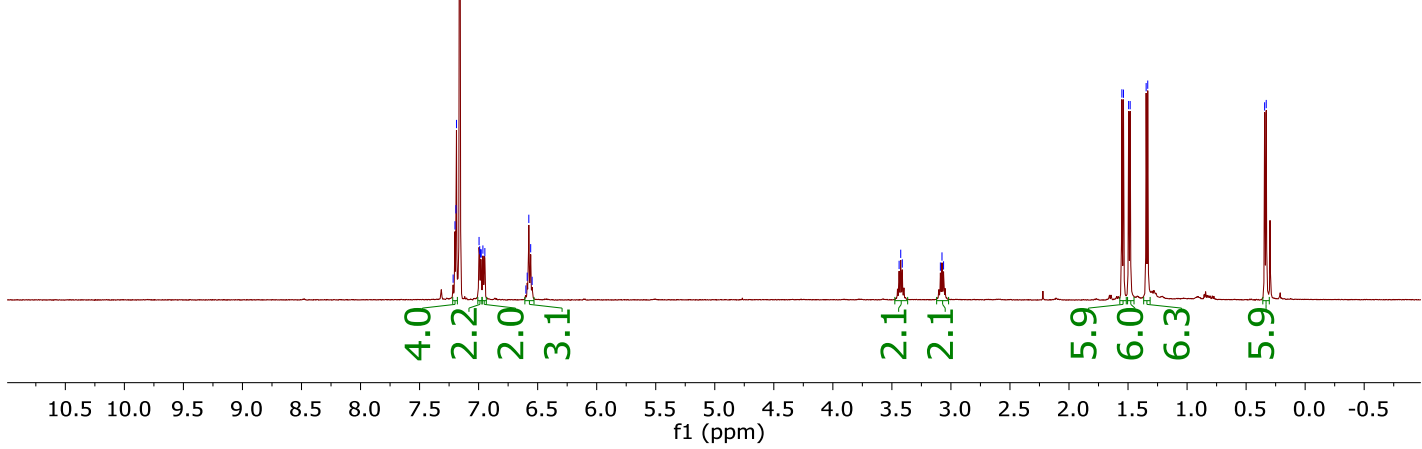

Figure S1. ${ }^{1} \mathrm{H}$ NMR $\left(500 \mathrm{MHz}, \mathrm{C}_{6} \mathrm{D}_{6}, 298 \mathrm{~K}\right)$ spectrum of compound 3.

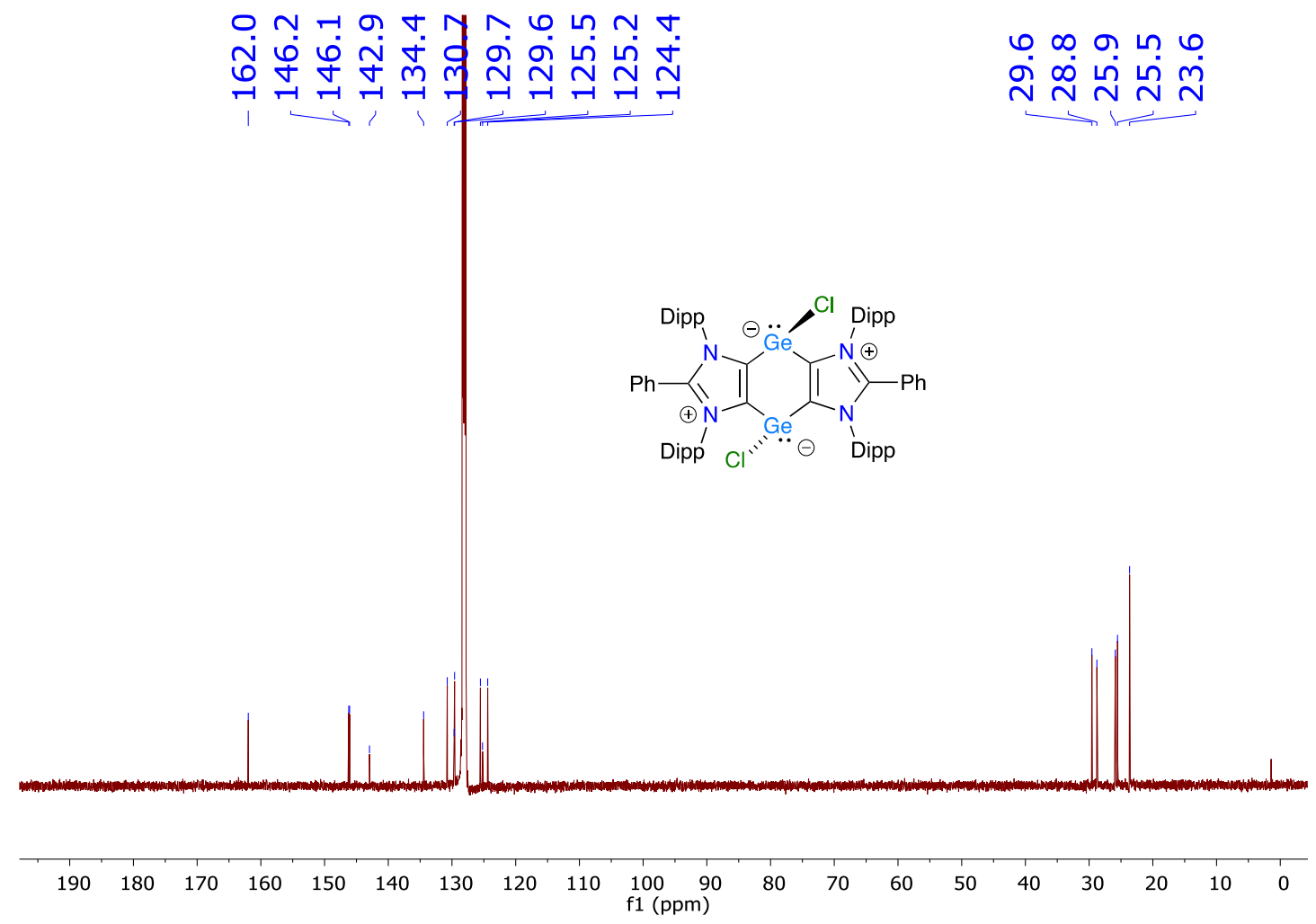

Figure S2 . ${ }^{13} \mathrm{C}\left\{{ }^{1} \mathrm{H}\right\} \mathrm{NMR}\left(125 \mathrm{MHz}, \mathrm{C}_{6} \mathrm{D}_{6}, 298 \mathrm{~K}\right)$ spectrum of compound 3. 


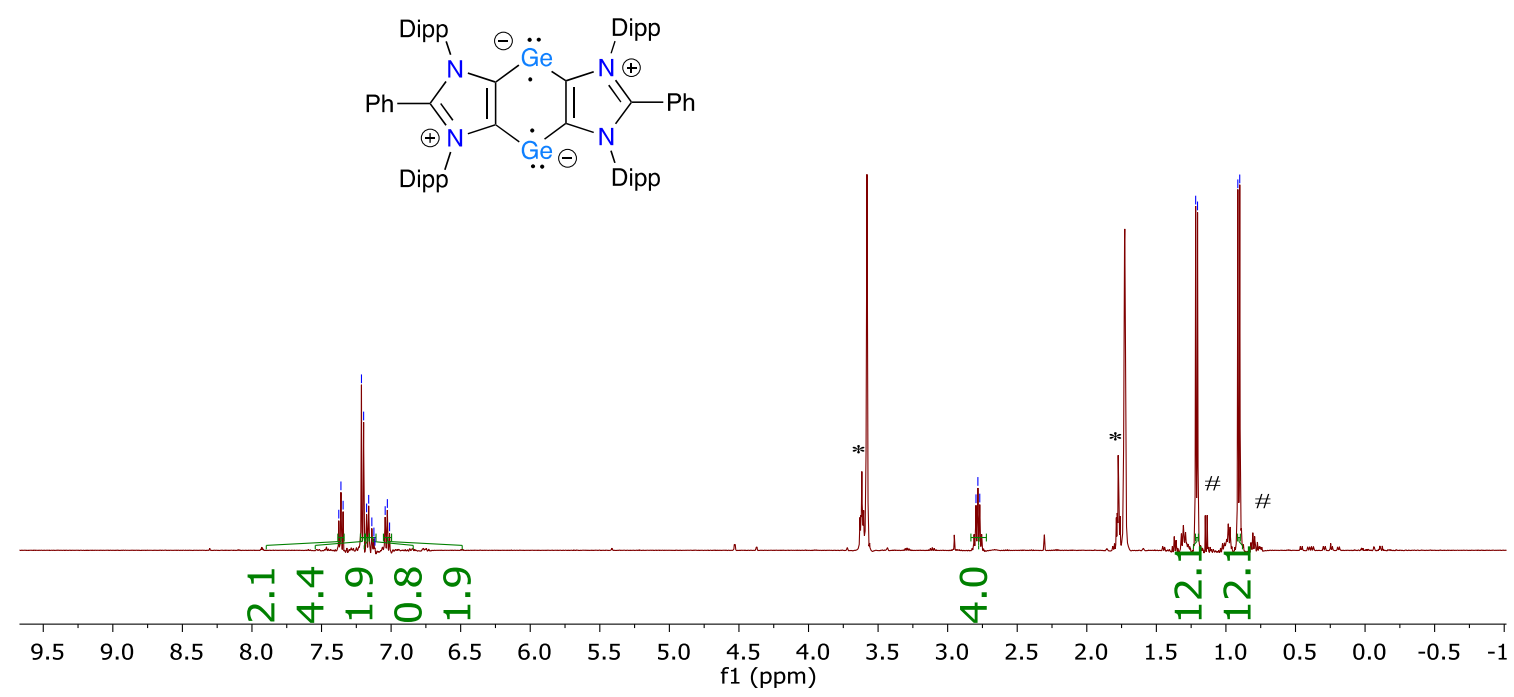

Figure S3. ${ }^{1} \mathrm{H}$ NMR $\left(500 \mathrm{MHz}, \mathrm{THF}-d_{8}, 298 \mathrm{~K}\right)$ spectrum of compound 4. (*THF; ${ }^{\#}$-Hexane)

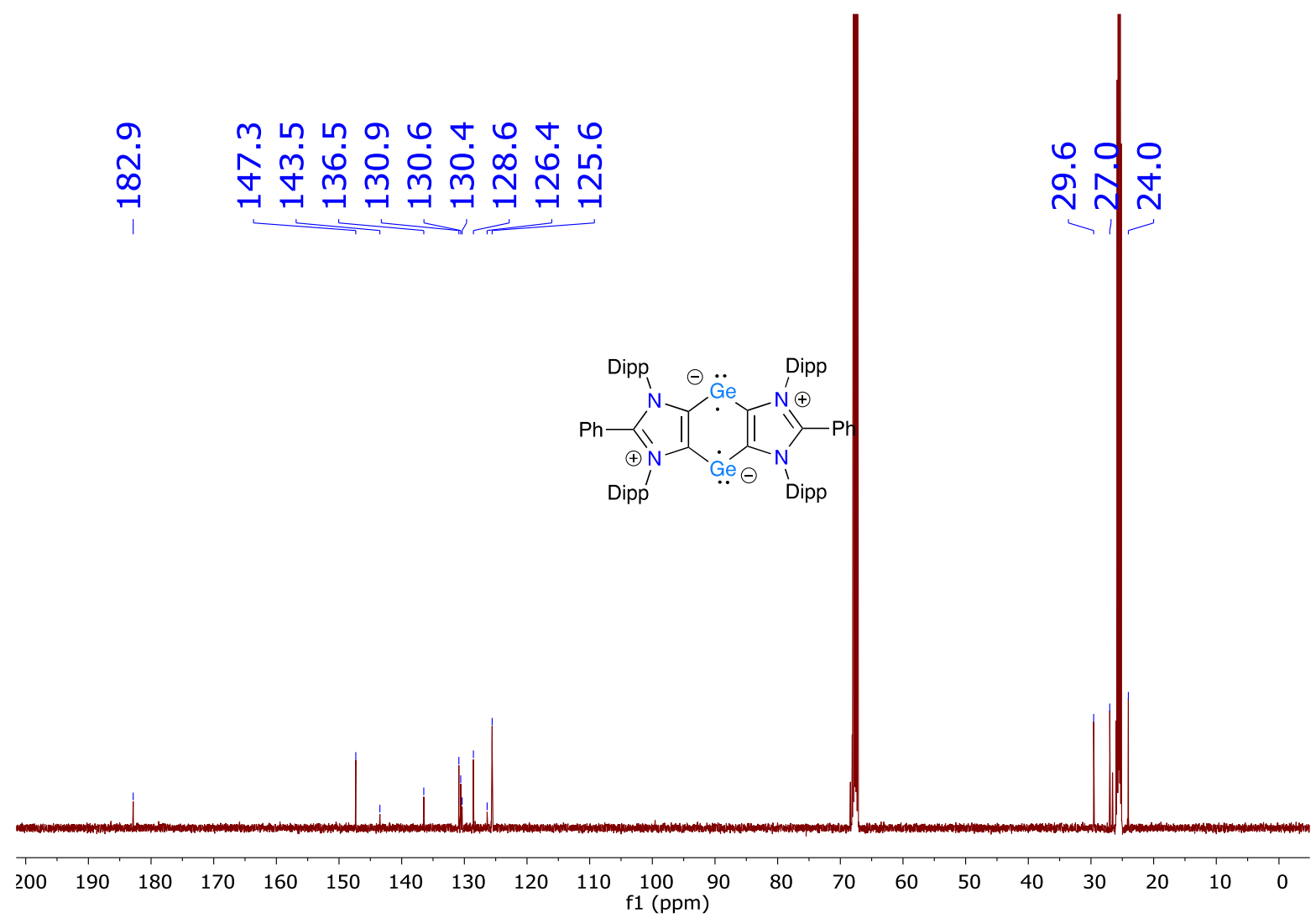

Figure S4. ${ }^{13} \mathrm{C}\left\{{ }^{1} \mathrm{H}\right\}$ NMR $\left(125 \mathrm{MHz}\right.$, THF- $d_{8}, 298 \mathrm{~K}$,) spectrum of compound 4. 


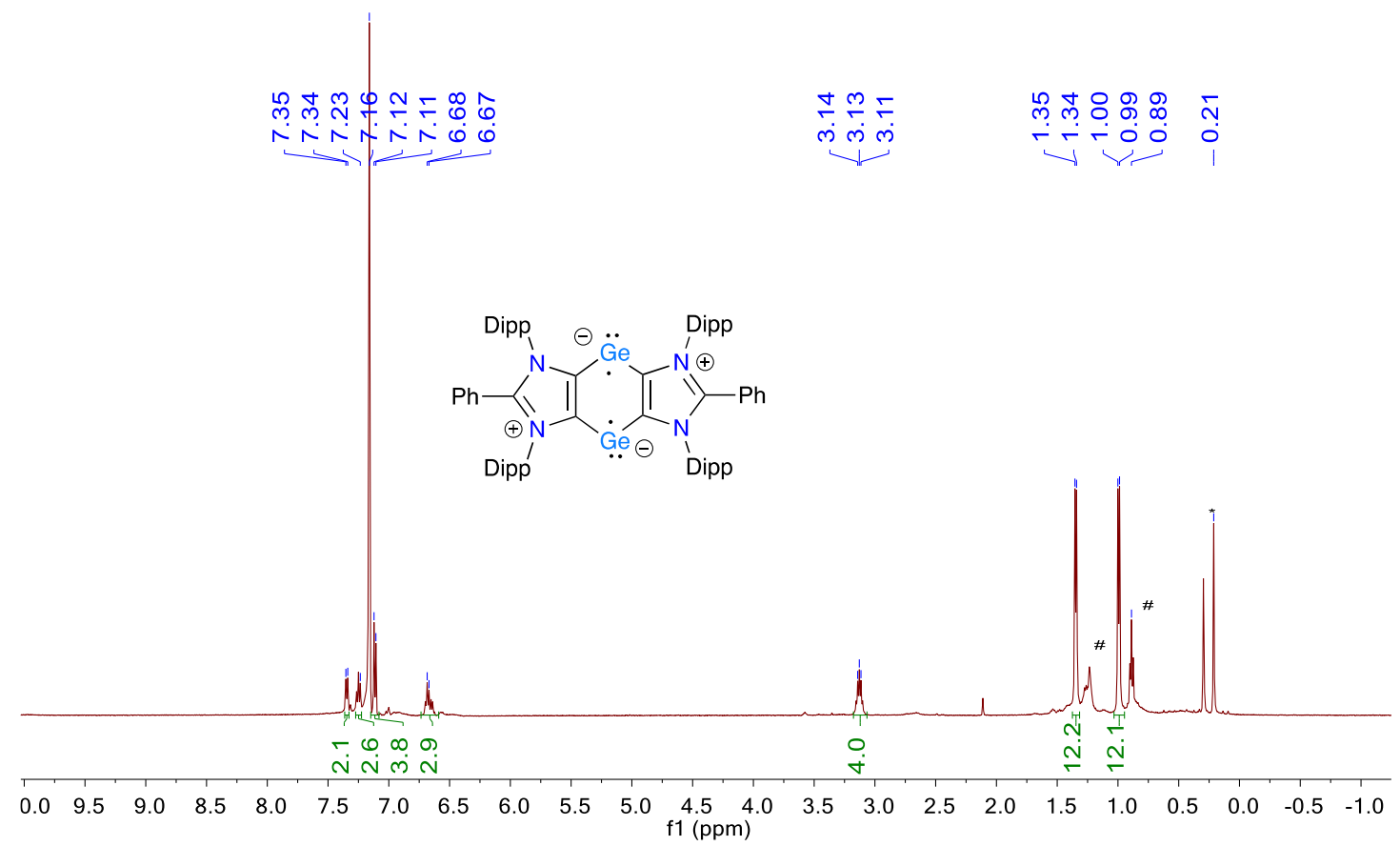

Figure S5. ${ }^{1} \mathrm{H}$ NMR $\left(500 \mathrm{MHz}, \mathrm{C}_{6} \mathrm{D}_{6}, 298 \mathrm{~K}\right)$ spectrum of 4 before addition of $\mathrm{H}_{2} .{ }^{\#} n$ Hexane, *Silicon grease.

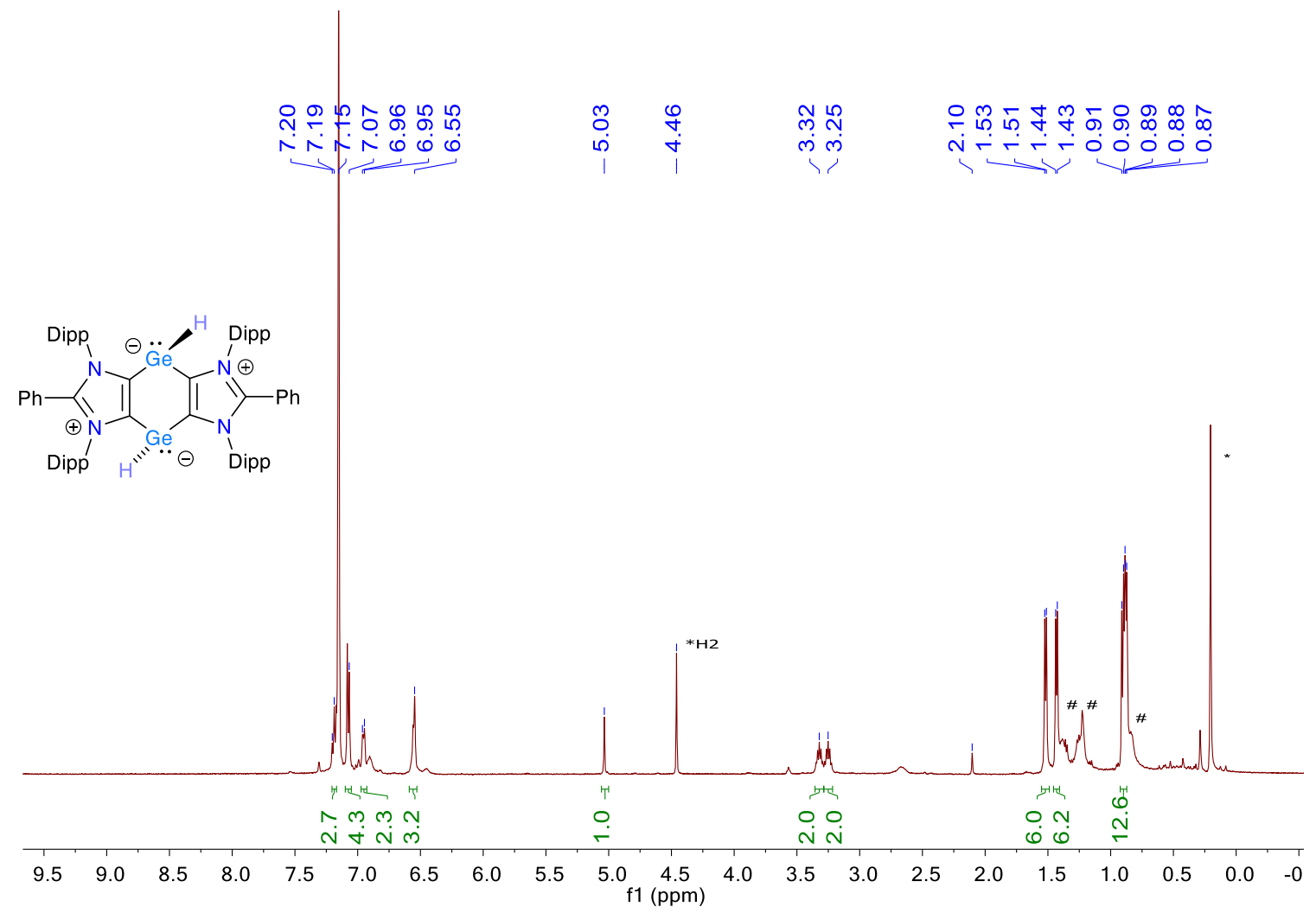

Figure S6. ${ }^{1} \mathrm{H}$ NMR $\left(500 \mathrm{MHz}, \mathrm{C}_{6} \mathrm{D}_{6}, 298 \mathrm{~K}\right.$ ) spectrum of 5 (after exposure of 4 to 1 atm $\left.\mathrm{H}_{2}\right) .{ }^{*} n$-Hexane; *Silicon grease. 

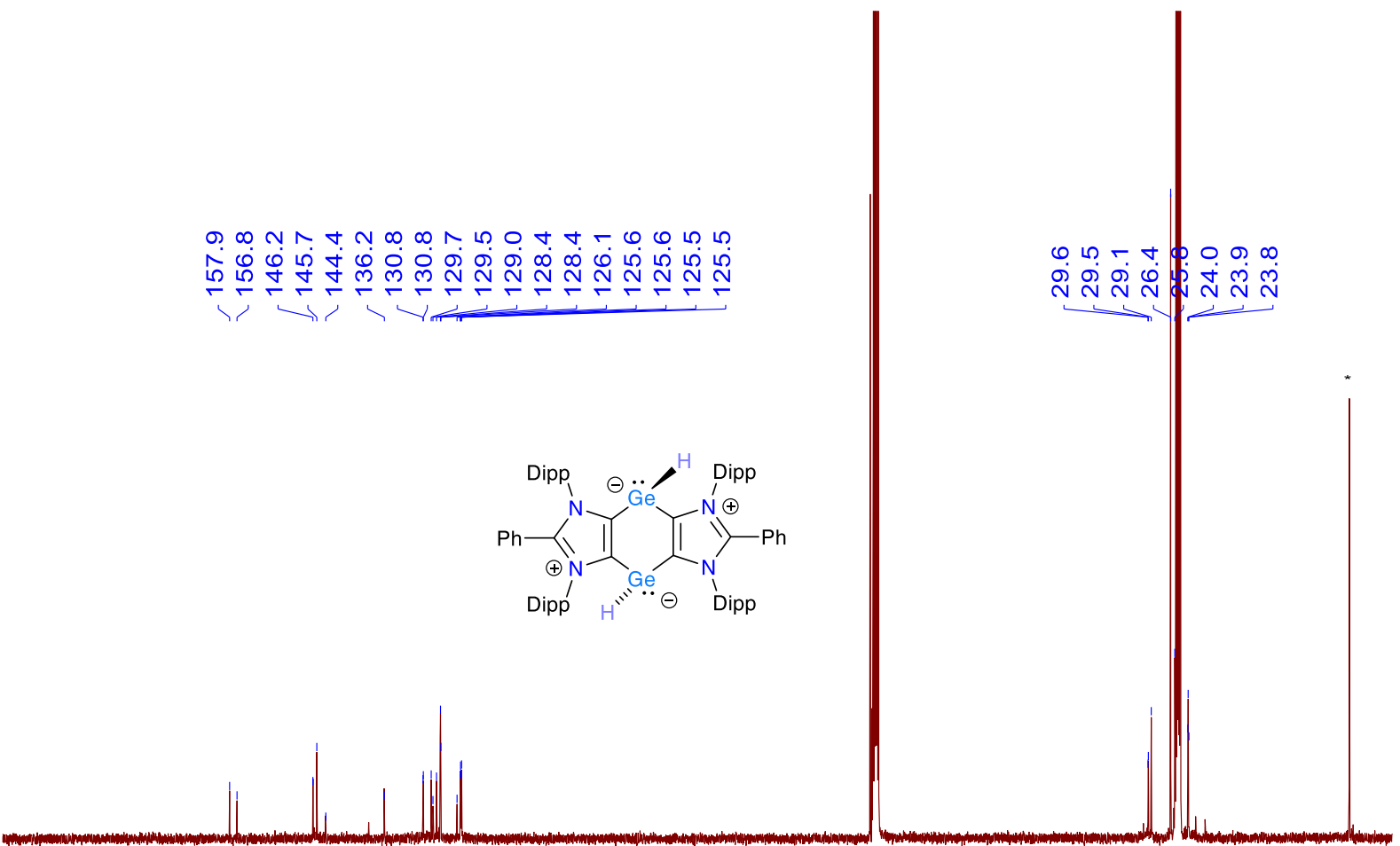

$\begin{array}{lllllllll}180 & 170 & 160 & 150 & 140 & 130 & 120 & 110 & 100 \\ \mathrm{f} 1(\mathrm{ppm}) & 90\end{array}$

50

$20 \quad 10 \quad 0$

Figure S7. ${ }^{13} \mathrm{C}\left\{{ }^{1} \mathrm{H}\right\}$ NMR $\left(125 \mathrm{MHz}, \mathrm{THF}-d_{8}, 298 \mathrm{~K}\right)$ spectrum of $\mathbf{5}$. *Silicon grease.

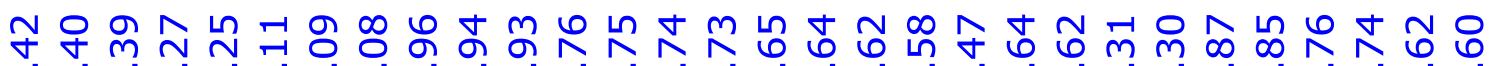

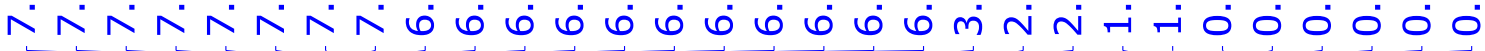

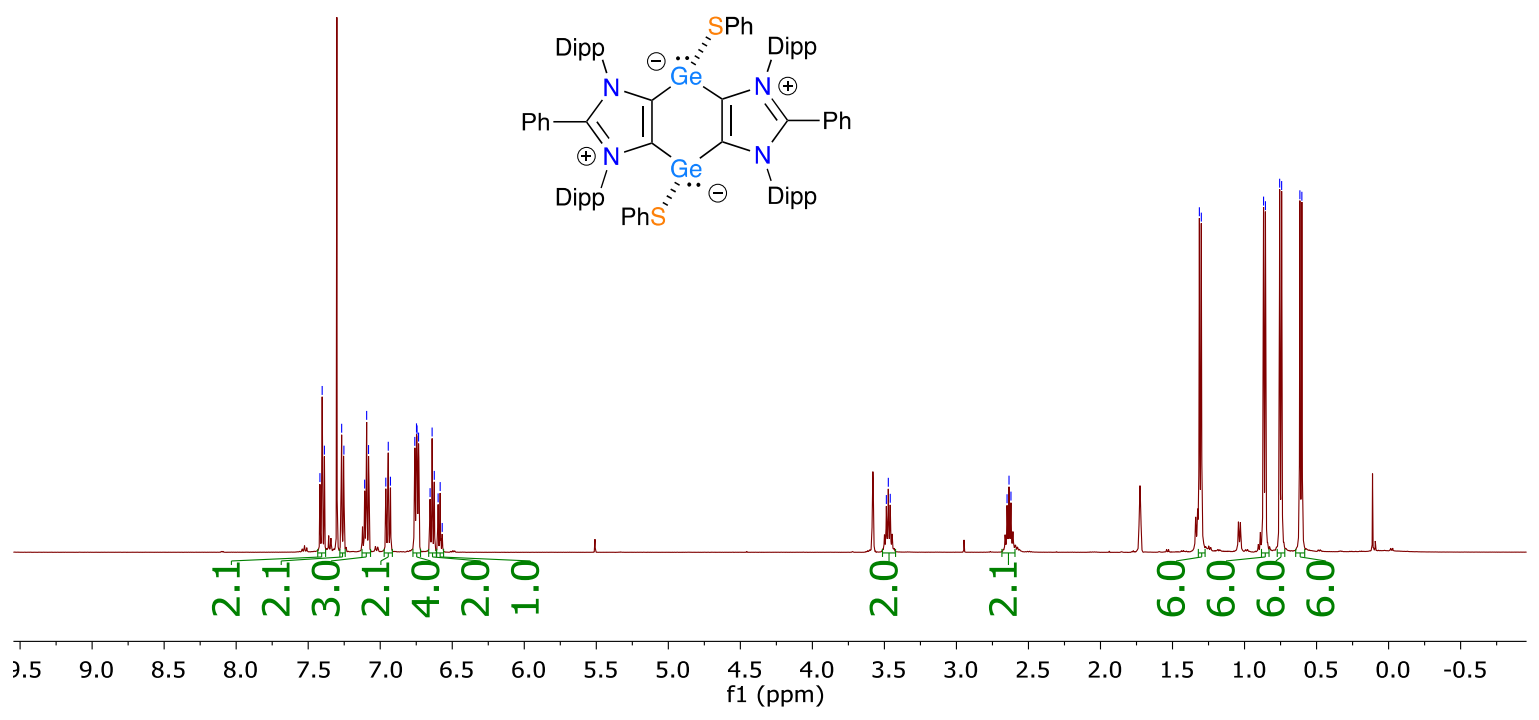

Figure S8. ${ }^{1} \mathrm{H}$ NMR $\left(500 \mathrm{MHz}, \mathrm{THF}-d_{8}, 298 \mathrm{~K}\right)$ spectrum of compound 5-S. 


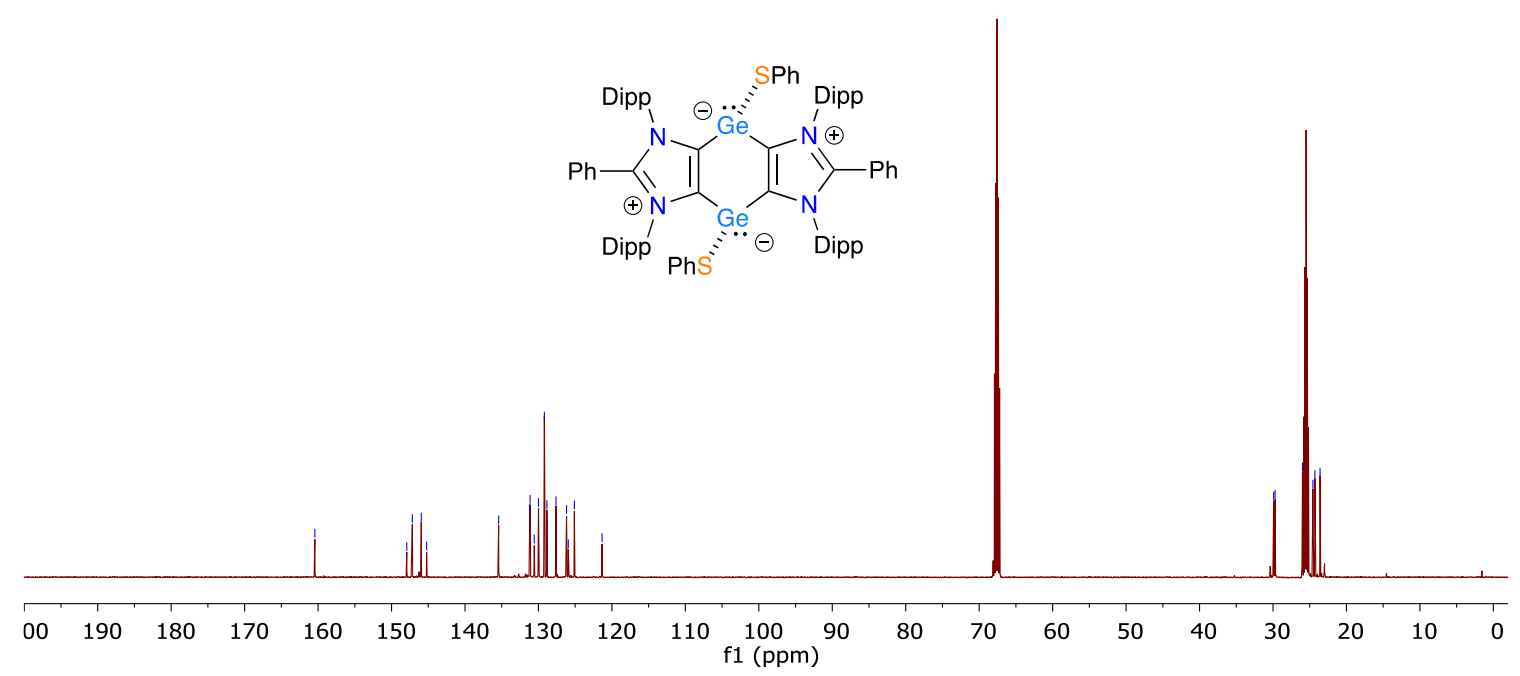

Figure S9. ${ }^{13} \mathrm{C}\left\{{ }^{1} \mathrm{H}\right\}$ NMR $\left(125 \mathrm{MHz}\right.$, THF- $\left.d_{8}, 298 \mathrm{~K}\right)$ spectrum of compound 5-S.

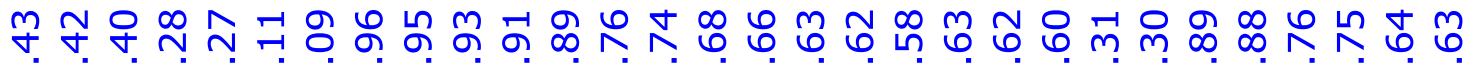

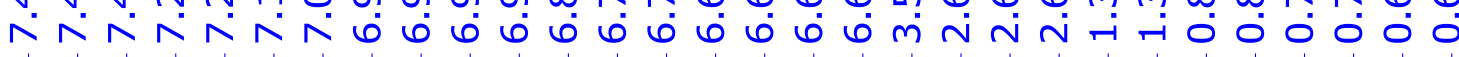

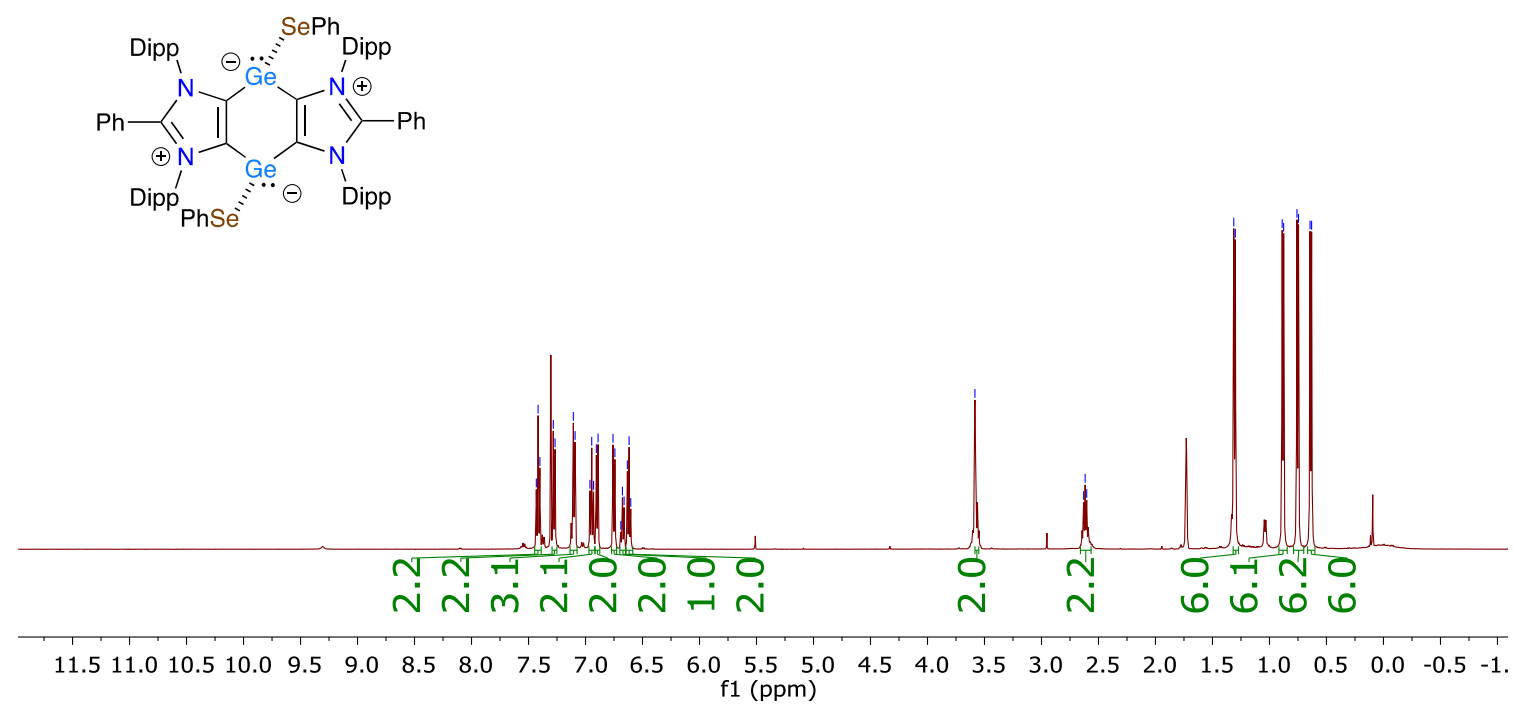

Figure S10. ${ }^{1} \mathrm{H}$ NMR (500 MHz, THF- $\left.d_{8}, 298 \mathrm{~K}\right)$ spectrum of compound 5-Se. 


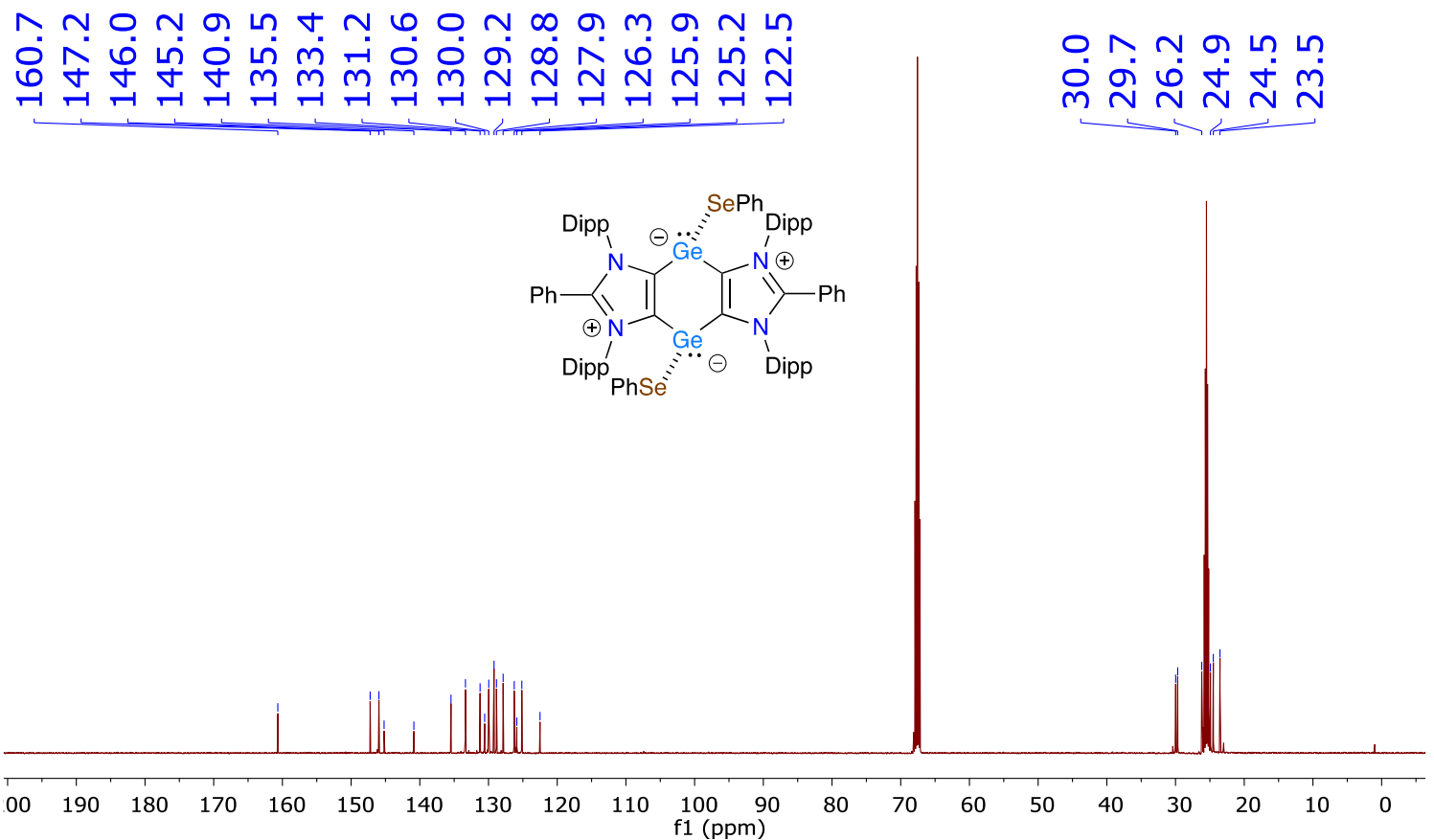

Figure S11. ${ }^{13} \mathrm{C}\left\{{ }^{1} \mathrm{H}\right\}$ NMR (125 MHz, THF- $\left.d_{8}, 298 \mathrm{~K}\right)$ spectrum of compound 5-Se.

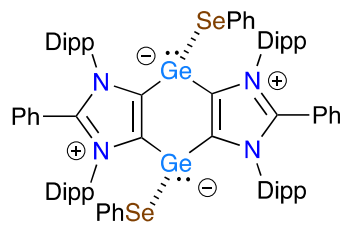

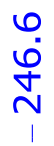

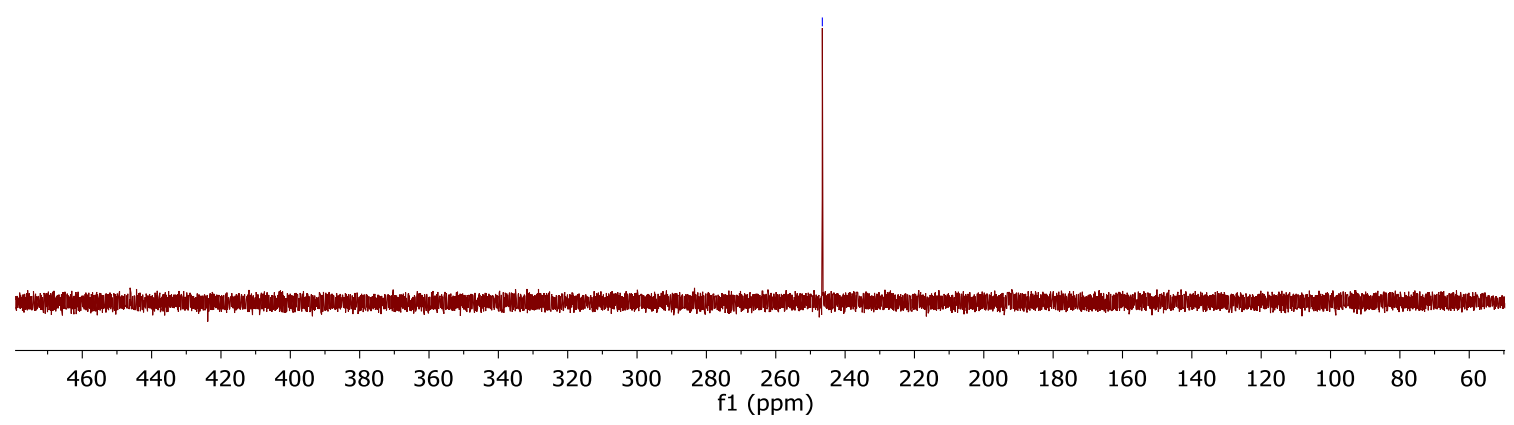

Figure S12. ${ }^{77} \mathrm{Se}\left\{{ }^{1} \mathrm{H}\right\} \mathrm{NMR}\left(95 \mathrm{MHz}, \mathrm{THF}-d_{8}, 298 \mathrm{~K}\right)$ spectrum of compound 5-Se. 


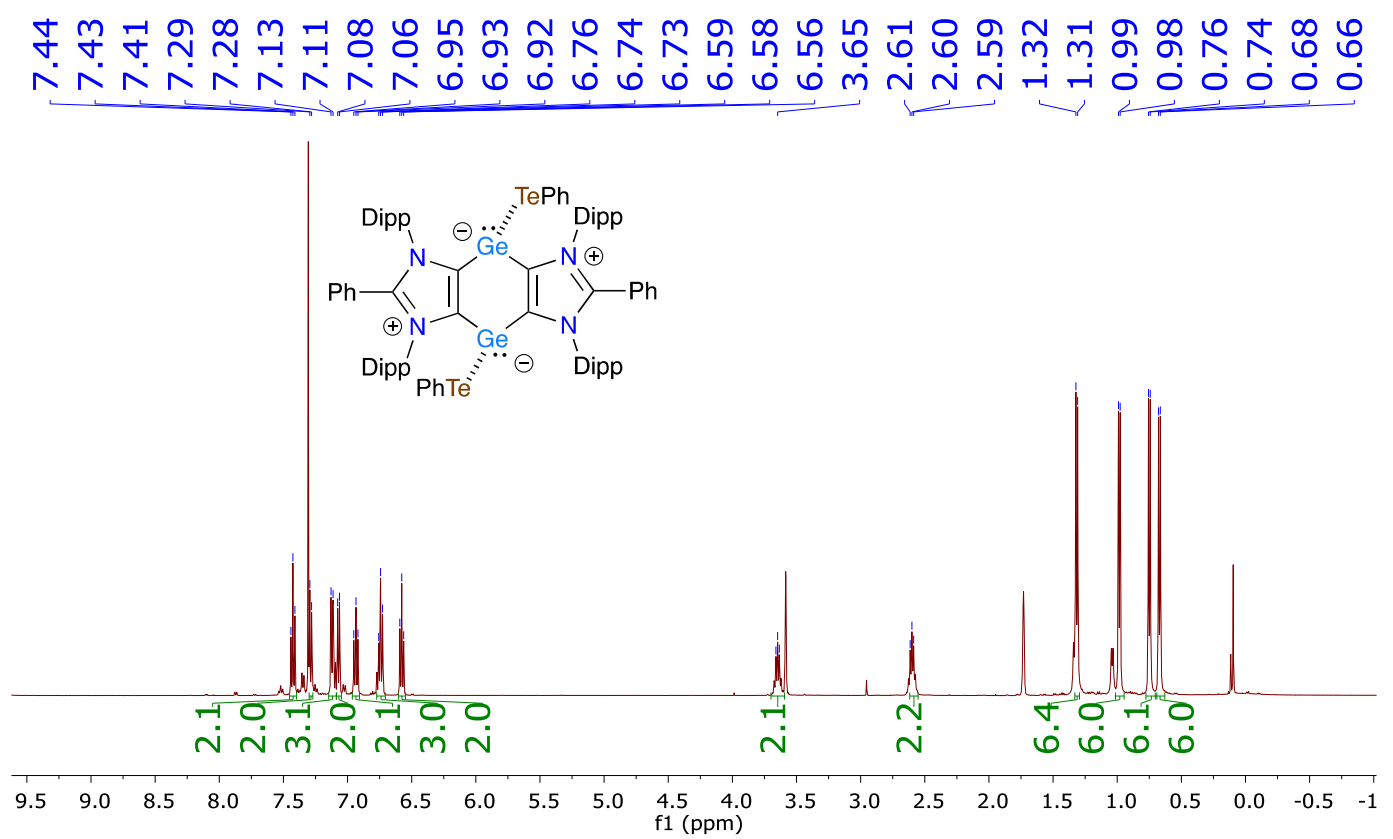

Figure S13. ${ }^{1} \mathrm{H}$ NMR (500 MHz, THF- $\left.d_{8}, 298 \mathrm{~K}\right)$ spectrum of compound 5-Te.

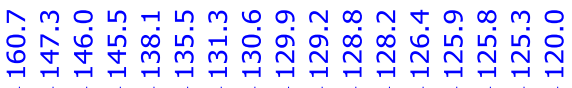
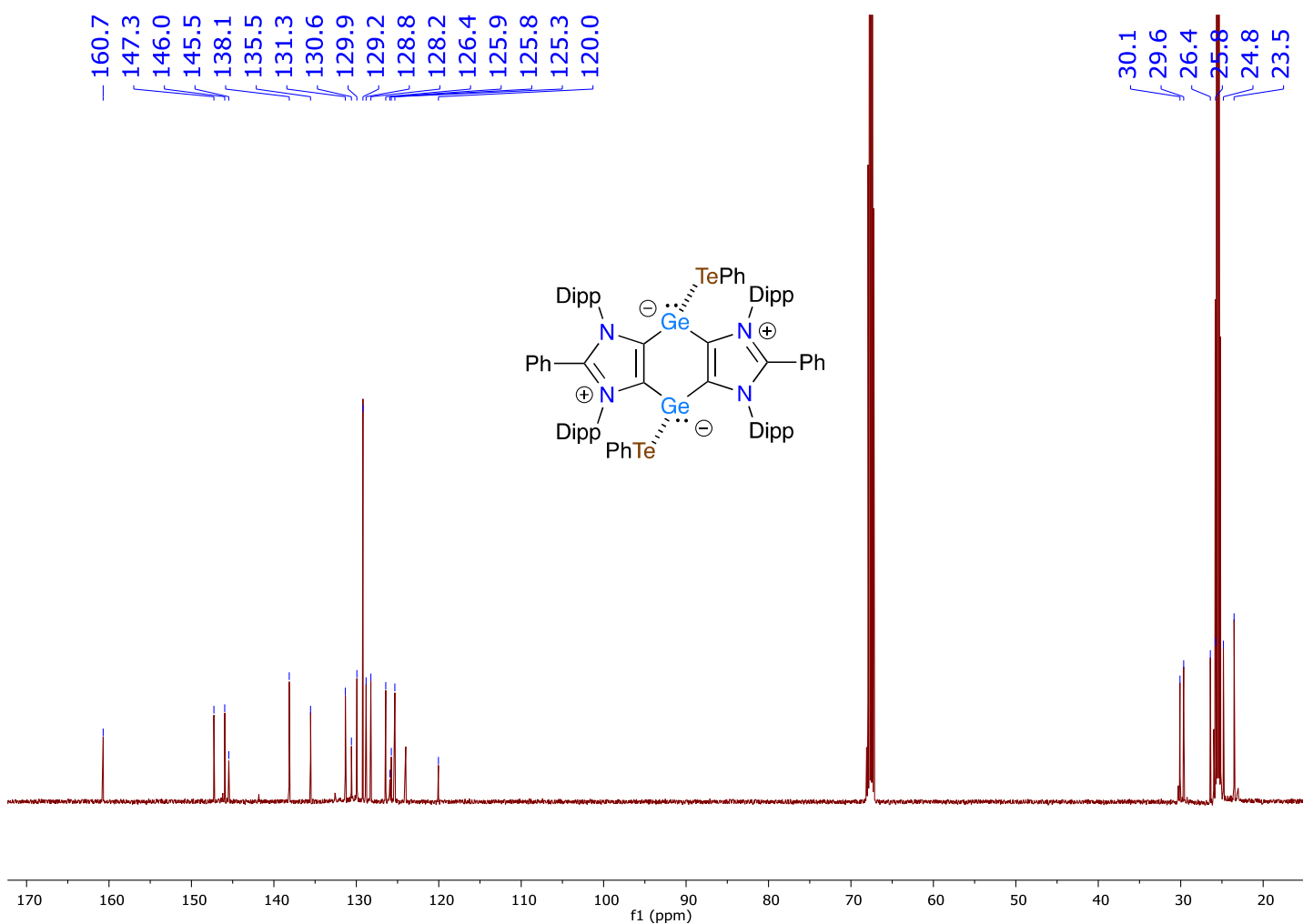

Figure S14. ${ }^{13} \mathrm{C}\left\{{ }^{1} \mathrm{H}\right\}$ NMR $\left(125 \mathrm{MHz}\right.$, THF- $\left.d_{8}, 298 \mathrm{~K}\right)$ spectrum of compound 5-Te. 

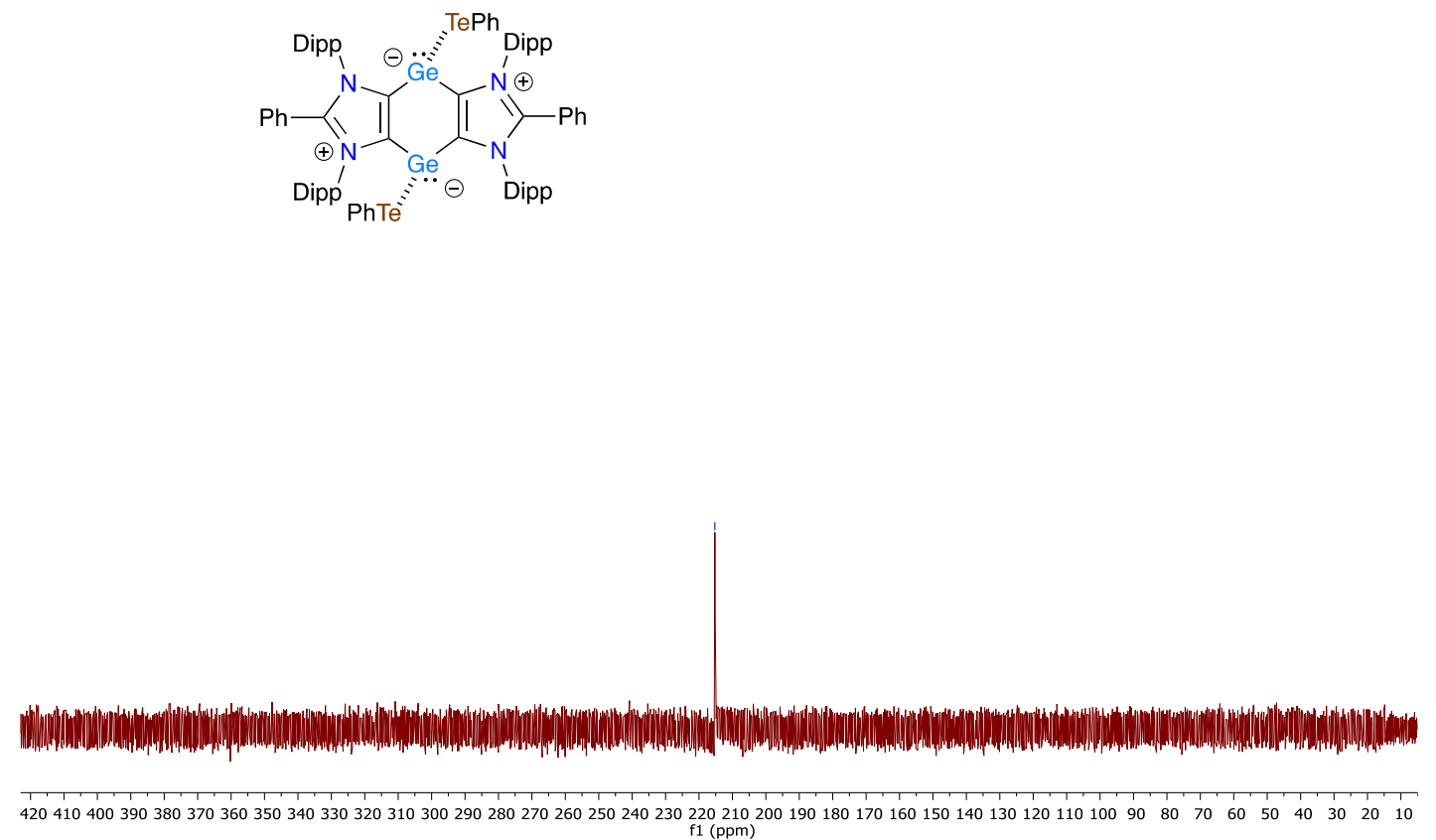

Figure S15. ${ }^{125} \mathrm{Te}\left\{{ }^{1} \mathrm{H}\right\}$ NMR $\left(158 \mathrm{MHz}, \mathrm{THF}-d_{8}, 298 \mathrm{~K}\right)$ spectrum of compound 5-Te. 


\section{UV-vis Spectra}

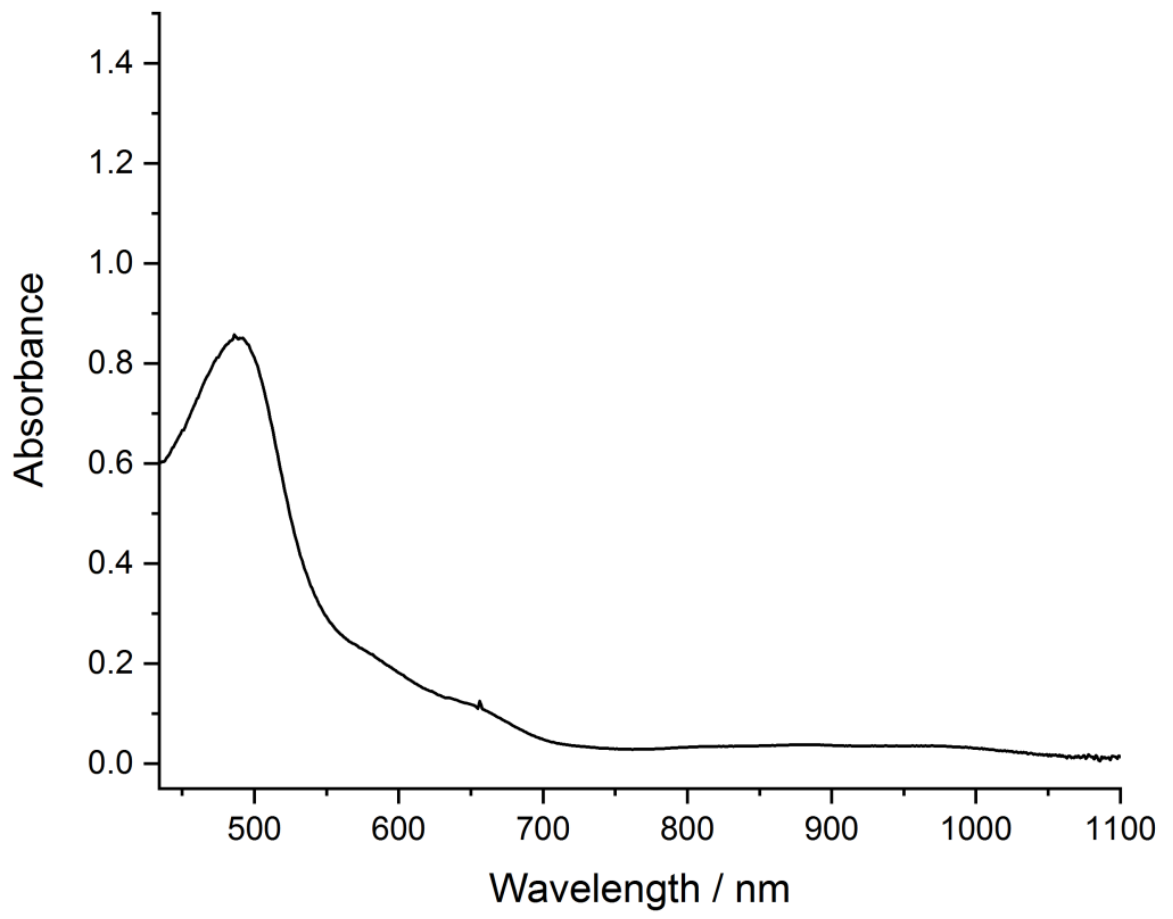

Figure S16. UV-vis spectrum of $\mathbf{4}\left(10^{-4} \mathrm{M}\right)$ recorded in THF.

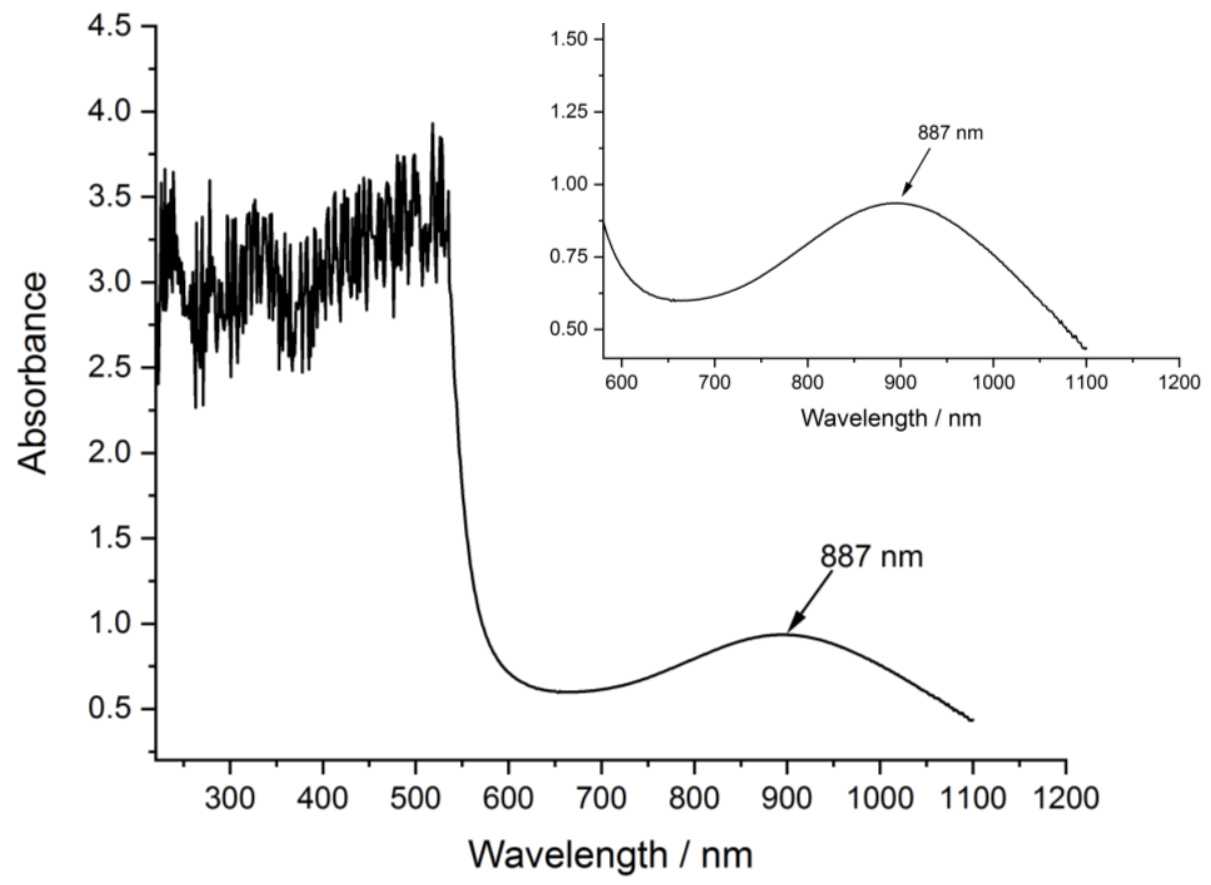

Figure S17. UV-vis spectrum of $\mathbf{4}\left(10^{-2} \mathrm{M}\right)$ recorded in THF. 


\section{Crystallographic Details}

The single crystal data were examined on a Rigaku Supernova diffractometer using either $\operatorname{MoK} \alpha(\lambda=0.71073 \AA)$ or $\operatorname{CuK} \alpha(\lambda=1.54184 \AA)$ radiation. The crystals were kept at 100.0 (1) K during data collection. Using Olex $2,{ }^{[5]}$ the structure was solved with the ShelXT ${ }^{[6]}$ structure solution program using Intrinsic Phasing and refined with the ShelXL ${ }^{[7]}$ refinement package using Least Squares minimization. Hydrogen atoms were taken into account using a riding model. Details of the X-ray investigation are given in Table S1, and S2. CCDC 1992499-1992502 contain contains the supplementary crystallographic data for this paper. These data can be obtained free of charge from The Cambridge Crystallographic Data Centre via www.ccdc.cam.ac.uk/conts/retrieving.html.

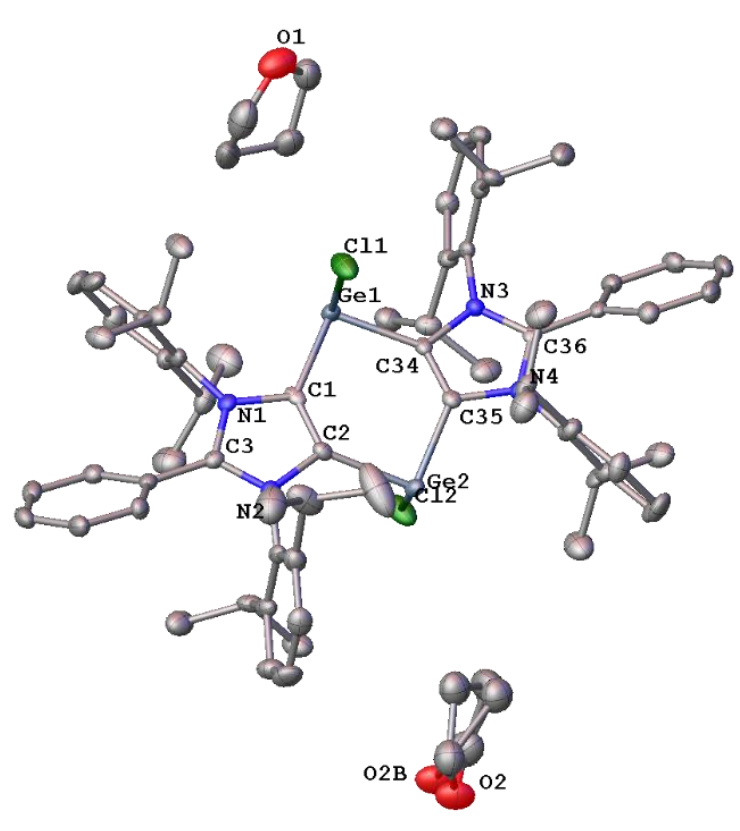

(a)

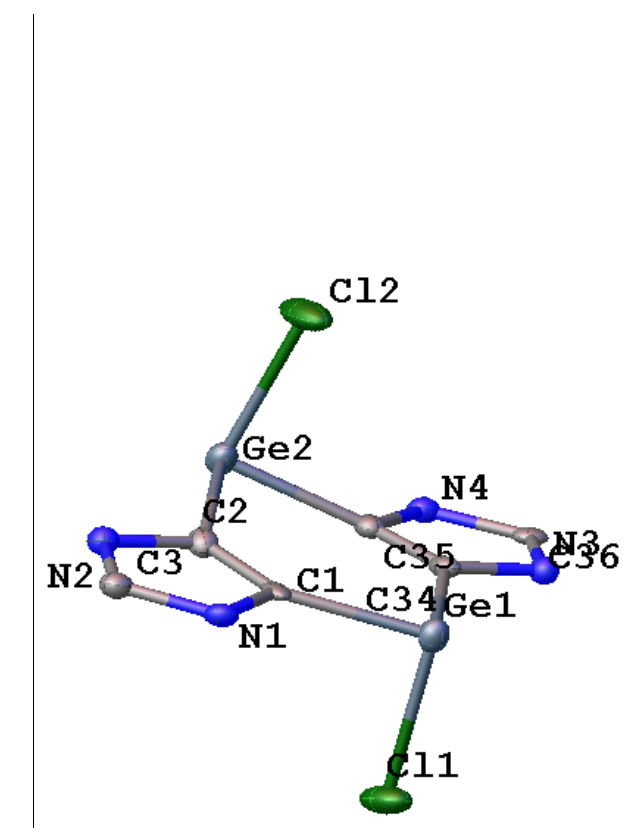

(b)

Figure S18. (a) Solid-state molecular structure of 3. Hydrogen atoms are omitted for clarity. Selected bond lengths $[\AA]$ and angles $\left[^{\circ}\right]$ : Ge1-Cl1 2.333(1), Ge2-Cl2 2.341(1), Ge1-C1 2.027(3), Ge1-C34 2.021(3), Ge2-C2 2.033(3), Ge2-C35 2.032(3), C1-C2 1.362(4), C34-C35 1.367(4); C1-Ge1-C11 91.8(1), C34-Ge1-C11 89.9(1), C1-Ge1-C34 92.2(1), C2-Ge2-C12 91.9(1), C35-Ge2-C12 89.5(1), C2-Ge1-C35 91.9(1). (b) Side-view of the central $\mathrm{CN}_{2} \mathrm{C}_{4} \mathrm{Ge}_{2} \mathrm{~N}_{2} \mathrm{C}$ core of $\mathbf{3}$. 


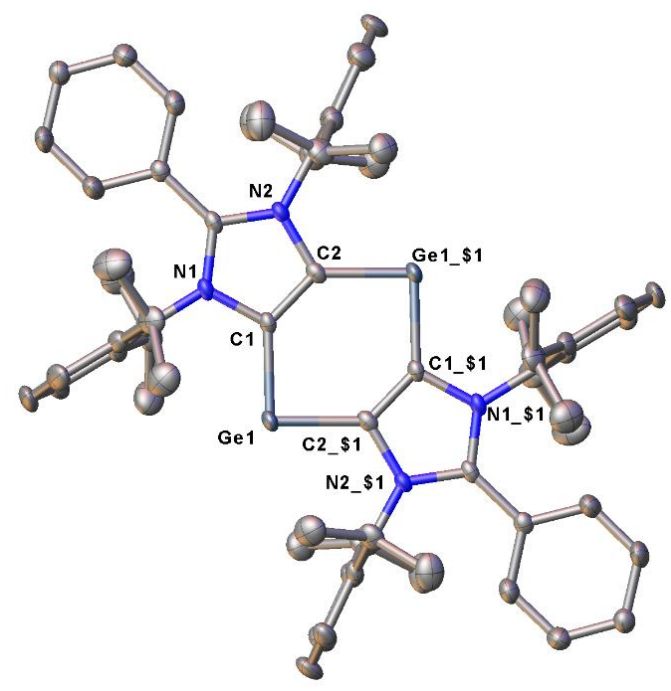

(a)
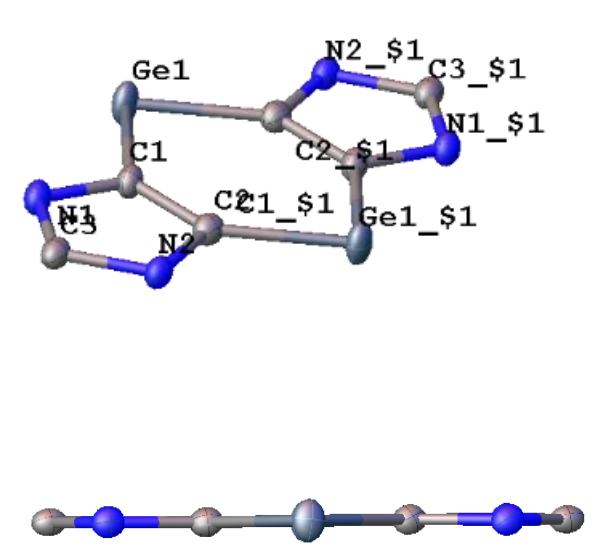

(b)

Figure S19. (a) Solid-state molecular structure of $\mathbf{4}$. Hydrogen atoms and solvent molecules are omitted for clarity. Selected bond lengths $[\AA \AA]$ and angles $\left[{ }^{\circ}\right]$ : Ge1-C1 1.963(2), Ge1-C2' 1.960(2), C1-C2 1.394(3), C1-N1 1.413(3), C2-N2 1.410(3); C1-Ge1-C2' 91.39(9), Ge1-C1-C2 134.9(2), N1-C1-C2 105.4(2), N2-C2-C1 105.8(2). 'Symmetry parameters were used to generate equivalent atoms 1-X,-Y,1-Z. (b) Side-views of the central $\mathrm{CN}_{2} \mathrm{C}_{4} \mathrm{Ge}_{2} \mathrm{~N} 2 \mathrm{C}$ core of 4 .

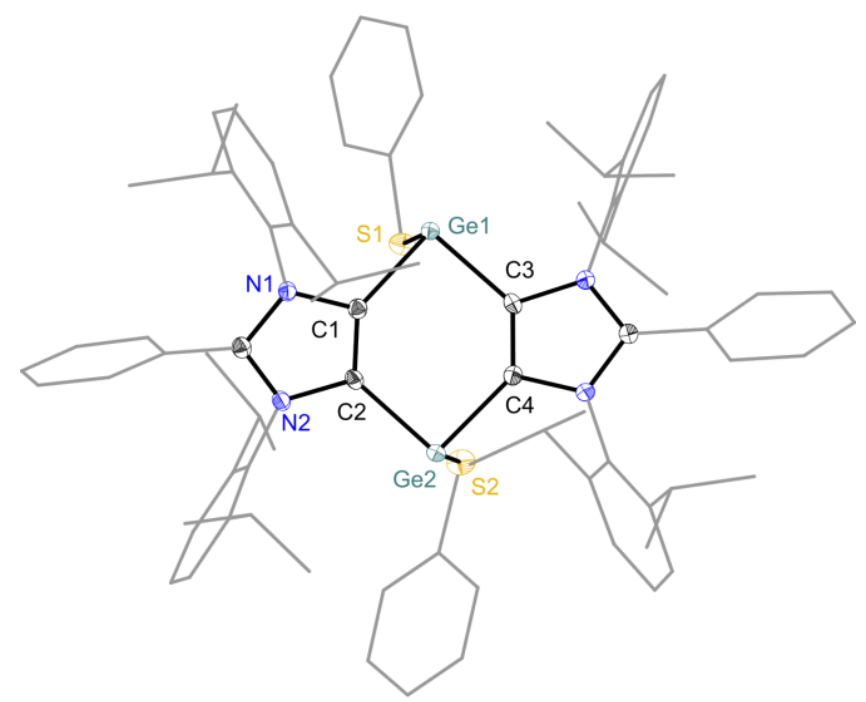

Figure S20. Solid-state molecular structure of 6-S. Hydrogen atoms and solvent molecules are omitted for clarity. Selected bond lengths $[\AA]$ and angles $\left[{ }^{\circ}\right]$ : Ge1-S1 2.360(1), Ge2-S2 2.339(1), Ge1-C1 2.029(2), Ge1-C3 2.025(2), Ge2-C2 2.028(2), Ge2-C4 2.033(2), C1-C2 1.378(3), C3-C4 1.375(3); C1-Ge1-S1 91.4(1), C3-Ge1-S1 97.1(1), C1-Ge1-C2 89.6(1), C3-Ge2-S2 101.8(1), C4-Ge2-S2 92.6(1), C2-Ge2-C4 91.1(1). 


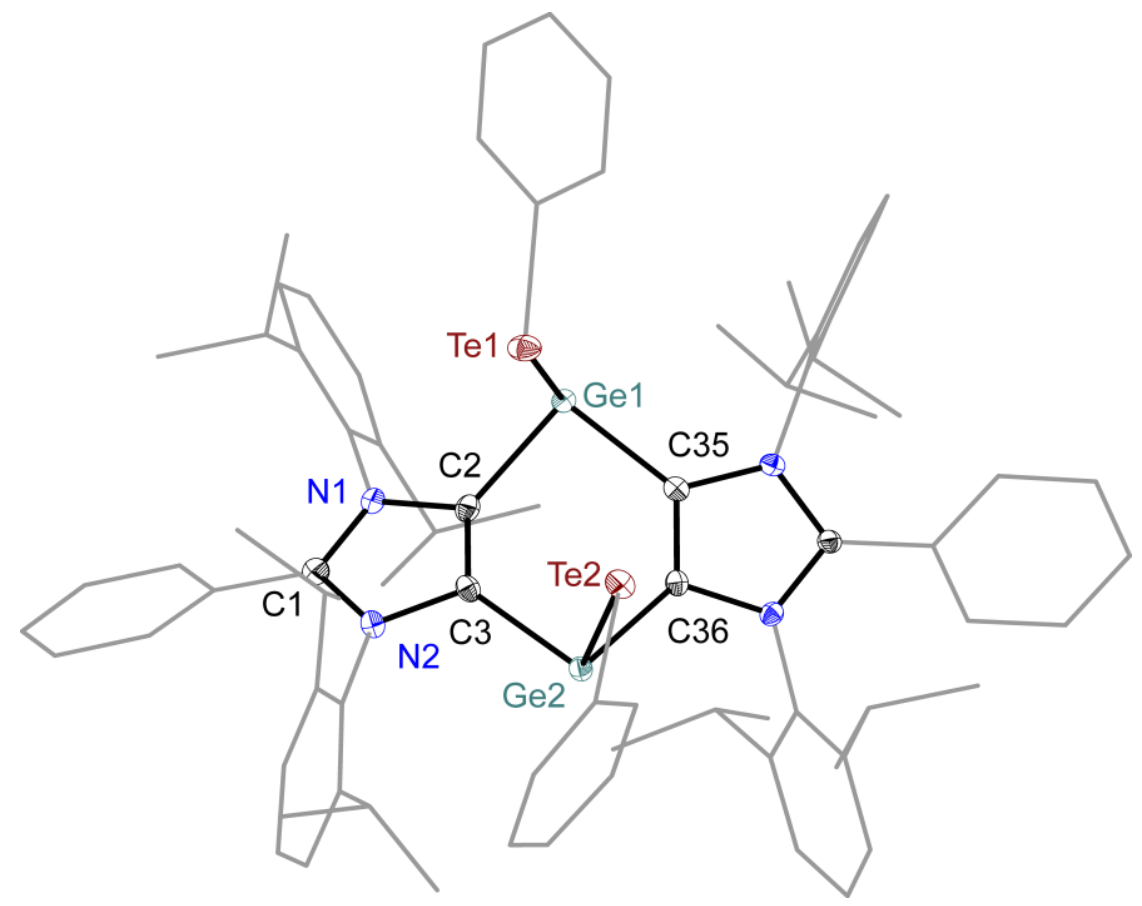

Figure S21. Solid-state molecular structure of 6-Te. Hydrogen atoms and solvent molecules

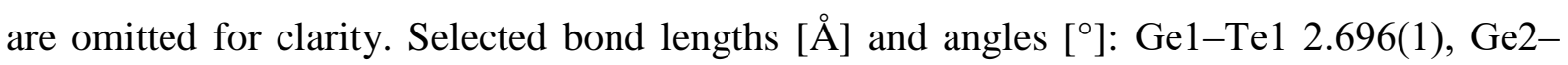
Te2 2.693(1), Ge1-C2 2.035(2), Ge1-C35 2.028(2), Ge2-C3 2.026(2), Ge2-C36 2.035(2), C2-C3 1.377(3), C35-C36 1.371(3); C2-Ge1-Te1 91.3(1), C35-Ge1-Te1 99.7(1), C2-Ge1-C35 90.8(1), C3-Ge2-Te2 99.2(1), C36-Ge2-Te2 89.7(1), C3-Ge2-C36 90.7(1). 
Table S1. Crystal data and structure refinement for compounds 3 and 4.

\begin{tabular}{|c|c|c|}
\hline & $3 \times 2$ THF & $4 \times \mathrm{THF}$ \\
\hline Empirical formula & $\mathrm{C}_{74} \mathrm{H}_{94} \mathrm{Cl}_{2} \mathrm{Ge}_{2} \mathrm{~N}_{4} \mathrm{O}_{2}$ & $\mathrm{C}_{70} \mathrm{H}_{86} \mathrm{Ge}_{2} \mathrm{~N}_{4} \mathrm{O}$ \\
\hline Formula weight & 1287.61 & 1144.60 \\
\hline Temperature/K & $100.0(1)$ & $100.0(1)$ \\
\hline Crystal system & monoclinic & triclinic \\
\hline Space group & $\mathrm{P} 2_{1} / \mathrm{c}$ & $\mathrm{P}-1$ \\
\hline $\mathrm{a} / \AA$ & $13.7437(4)$ & $12.8343(4)$ \\
\hline $\mathrm{b} / \AA$ & $20.2913(4)$ & $14.2908(5)$ \\
\hline $\mathrm{c} / \AA$ & $24.8641(4)$ & $17.1398(6)$ \\
\hline$\alpha / /^{\circ}$ & 90 & $82.394(3)$ \\
\hline$\beta /^{\circ}$ & $98.358(2)$ & $84.112(3)$ \\
\hline$\gamma /{ }^{\circ}$ & 90 & $87.309(3)$ \\
\hline Volume $/ \AA^{3}$ & $6860.4(3)$ & $3097.78(19)$ \\
\hline $\mathrm{Z}$ & 4 & 2 \\
\hline$\rho_{\text {calc }} \mathrm{g} / \mathrm{cm}^{3}$ & 1.247 & 1.227 \\
\hline$\mu / \mathrm{mm}^{-1}$ & 1.001 & 1.532 \\
\hline $\mathrm{F}(000)$ & 2720.0 & 1212.0 \\
\hline Crystal size $/ \mathrm{mm}^{3}$ & $0.304 \times 0.225 \times 0.18$ & $0.146 \times 0.109 \times 0.081$ \\
\hline Radiation/Å & Mo $\mathrm{K} \alpha(\lambda=0.71073)$ & $\mathrm{Cu} \mathrm{K \alpha}(\lambda=1.54184)$ \\
\hline $2 \Theta$ range for data collection $/^{\circ}$ & 2.996 to 52.044 & 5.226 to 152.904 \\
\hline Index ranges & $\begin{array}{l}-16 \leq \mathrm{h} \leq 16,-25 \leq \mathrm{k} \leq 25,-30 \\
\leq 1 \leq 30\end{array}$ & $\begin{array}{l}-16 \leq \mathrm{h} \leq 15,-17 \leq \mathrm{k} \leq 17,- \\
21 \leq 1 \leq 21\end{array}$ \\
\hline Reflections collected & 172538 & 26968 \\
\hline Independent reflections & $\begin{array}{l}13326\left[R_{\text {int }}=0.0987, R_{\text {sigma }}=\right. \\
0.0738]\end{array}$ & $\begin{array}{l}12689\left[\mathrm{R}_{\mathrm{int}}=0.0371, \mathrm{R}_{\text {sigma }}=\right. \\
0.0469]\end{array}$ \\
\hline Reflections with $I>2 \sigma(I)$ & 8674 & 10505 \\
\hline Data/restraints/parameters & $13326 / 0 / 783$ & $12689 / 0 / 710$ \\
\hline Goodness-of-fit on $\mathrm{F}^{2}$ & 1.029 & 1.032 \\
\hline Final $\mathrm{R}$ indexes $[I>2 \sigma(I)]$ & $\mathrm{R}_{1}=0.0515, \mathrm{wR}_{2}=0.1263$ & $\mathrm{R}_{1}=0.0459, \mathrm{wR}_{2}=0.1143$ \\
\hline Final $\mathrm{R}$ indexes [all data] & $\mathrm{R}_{1}=0.0838, \mathrm{wR}_{2}=0.1325$ & $\mathrm{R}_{1}=0.0576, \mathrm{wR}_{2}=0.1214$ \\
\hline $\mathrm{CCDC}$ & 1992499 & 1992500 \\
\hline
\end{tabular}


Table S2. Crystal data and structure refinement for compounds 6-S and 6-Te.

\begin{tabular}{|c|c|c|}
\hline & 6-S x 1.5 benzene & 6-Te $\times 2$ benzene \\
\hline Empirical formula & $\mathrm{C}_{87} \mathrm{H}_{97} \mathrm{Ge}_{2} \mathrm{~N}_{4} \mathrm{~S}_{2}$ & $\mathrm{C}_{90} \mathrm{H}_{100} \mathrm{Ge}_{2} \mathrm{~N}_{4} \mathrm{Te}_{2}$ \\
\hline Formula weight & 1407.98 & 1638.11 \\
\hline Temperature/K & $100.0(1)$ & $100.0(1)$ \\
\hline Crystal system & triclinic & orthorhombic \\
\hline Space group & $\mathrm{P}-1$ & Pbca \\
\hline $\mathrm{a} / \AA$ & $11.0725(3)$ & $24.2191(4)$ \\
\hline $\mathrm{b} / \AA$ & $16.4856(6)$ & $23.9973(5)$ \\
\hline $\mathrm{c} / \AA$ & $22.3612(7)$ & $27.2389(5)$ \\
\hline$\alpha / /^{\circ}$ & $101.491(3)$ & 90 \\
\hline$\beta /^{\circ}$ & $101.127(2)$ & 90 \\
\hline$\gamma /{ }^{\circ}$ & $100.578(2)$ & 90 \\
\hline Volume $/ \AA^{3}$ & $3818.7(2)$ & $15831.1(5)$ \\
\hline $\mathrm{Z}$ & 2 & 8 \\
\hline$\rho_{\text {calc }} \mathrm{g} / \mathrm{cm}^{3}$ & 1.225 & 1.375 \\
\hline$\mu / \mathrm{mm}^{-1}$ & 0.888 & 1.529 \\
\hline $\mathrm{F}(000)$ & 1486.0 & 6688.0 \\
\hline Crystal size $/ \mathrm{mm}^{3}$ & $0.436 \times 0.171 \times 0.068$ & $0.381 \times 0.125 \times 0.03$ \\
\hline Radiation/Å & Mo $\mathrm{K} \alpha(\lambda=0.71073)$ & Mo $K \alpha(\lambda=0.71073)$ \\
\hline $2 \Theta$ range for data collection $/^{\circ}$ & 3.576 to 64.534 & 3.364 to 64.444 \\
\hline Index ranges & $\begin{array}{l}-16 \leq \mathrm{h} \leq 16,-21 \leq \mathrm{k} \leq 23,-31 \\
\leq 1 \leq 33\end{array}$ & $\begin{array}{l}-35 \leq \mathrm{h} \leq 35,-34 \leq \mathrm{k} \leq 35,-40 \\
\leq 1 \leq 40\end{array}$ \\
\hline Reflections collected & 44605 & 194842 \\
\hline Independent reflections & $\begin{array}{l}24015\left[R_{\text {int }}=0.0313, R_{\text {sigma }}=\right. \\
0.0603]\end{array}$ & $\begin{array}{l}26402\left[\mathrm{R}_{\text {int }}=0.0758, \mathrm{R}_{\text {sigma }}=\right. \\
0.0573]\end{array}$ \\
\hline Reflections with $I>2 \sigma(I)$ & 18216 & 19042 \\
\hline Data/restraints/parameters & $24015 / 0 / 872$ & $26402 / 0 / 899$ \\
\hline Goodness-of-fit on $\mathrm{F}^{2}$ & 1.044 & 1.046 \\
\hline Final $\mathrm{R}$ indexes $[I>2 \sigma(I)]$ & $\mathrm{R}_{1}=0.0460, \mathrm{w} \mathrm{R}_{2}=0.0914$ & $\mathrm{R}_{1}=0.0409, \mathrm{wR}_{2}=0.0721$ \\
\hline Final $\mathrm{R}$ indexes [all data] & $\mathrm{R}_{1}=0.0698, \mathrm{w} \mathrm{R}_{2}=0.1006$ & $\mathrm{R}_{1}=0.0735, \mathrm{wR}_{2}=0.0815$ \\
\hline $\mathrm{CCDC}$ & 1992501 & 1992502 \\
\hline
\end{tabular}




\section{Computational Details}

The geometry optimizations were performed using Gaussian 16 program suite using the B3LYP-D3BJ/6-31G(d) level of theory. ${ }^{[8-10]}$ The integral accuracy was internally set to $10^{-6}$ $E_{\mathrm{H}}$ with an ultrafine grid. Symmetry was used whenever possible and was always $C_{\mathrm{i}}$ symmetry. The coordinates used for the geometry optimizations of compounds $\mathbf{3}$ and $\mathbf{4}$ were obtained from single-crystal X-ray diffraction studies. Frequency calculations were carried out for all the optimized geometries to characterize the stationary points as minima. By default, DFT calculations were performed in a restricted manner, however, for open-shell systems, calculations were carried out in an unrestricted fashion (Table S3). The aforementioned DFT functional in combination with the def2-TZVPP and the optimized coordinates were used for performing the Weinhold's natural bond orbital (NBO) analysis ${ }^{[11]}$ and the Nuclear Independent Chemical Shifts (NICS). ${ }^{[12]}$

The Wiberg Bond Indices (WBI) ${ }^{[13]}$ and NPA ${ }^{[11]}$ atomic partial charges were calculated at the same level of theory using the NBO 3.1 interface of Gaussian.

For the frontier molecular orbital (FMO) analysis, the ORCA 4.2.1 software ${ }^{[14]}$ was used, which was combined with RIJCOSX approximation. ${ }^{[15]}$ For the solvation models, the Conductor-like Polarizable Continuum Model ${ }^{[16]}$ was used.

CASSCF calculations ${ }^{[17]}$ for compound 4 were performed with the ORCA 4.2.1 software. ${ }^{[14]}$ The CASSCF active space $(10,10)$ comprise ten electrons distributed in ten orbitals originating from the $\pi$ and $\pi^{*}$ orbitals of germanium and carbon atoms of the central $\mathrm{C}_{4} \mathrm{Ge}_{2}$ framework along with the $\sigma$ and $\sigma^{*}$ orbitals of the Ge atoms. Each of the Ge atoms has one lone-pair and one unpaired electron. The lone-pair is located in the $\sigma$-type orbital while the unpaired electron is situated in the orthogonal p-type orbital. Each of the carbon atoms of the $\mathrm{C}_{4} \mathrm{Ge}_{2}$ moiety has one electron in a p-type orbital that is parallel to that of the germanium $\mathrm{p}$ orbital. The starting structure was taken from the from the solid state and optimized on B3LYP-D3BJ/6-31G(d) level of theory. B3LYP-D3BJ/def2-TZVPP calculations were performed to generate the starting orbitals employing the resolution of identity chain of spheres (RIJCOSX) approximation. ${ }^{[15]}$ The resulting MOs of 4 were considered for the active space. For the CASSCF framework three singlet (141 symmetry configurations) and triplet (121 symmetry configurations) states were considered equally weighted. Throughout the CASSCF calculations, the def2-TZVPP was used in combination with the "autoaux" 
option. ${ }^{[18]}$ The diradical character of $\mathbf{4}$ was calculated according to literature methods. ${ }^{[19]}$ Thermodynamics were calculated using the quasi rigid rotator harmonic oscillator (QRRHO) approximation to predict the Gibbs Energies. ${ }^{[20]}$ Therefore, the optimized coordinates from B3LYP/6-31G(d) (Gaussain16) were taken into account, while the frequencies were obtained by B3LYP/def2SVP on top of B3LYP/def2TZVPPenergies (ORCA 4.2.1). ${ }^{[21]}$ Furthermore, Dispersion D3 in combination with Becke-Johnson-Damping was used throughout the calculations. $^{[22]}$

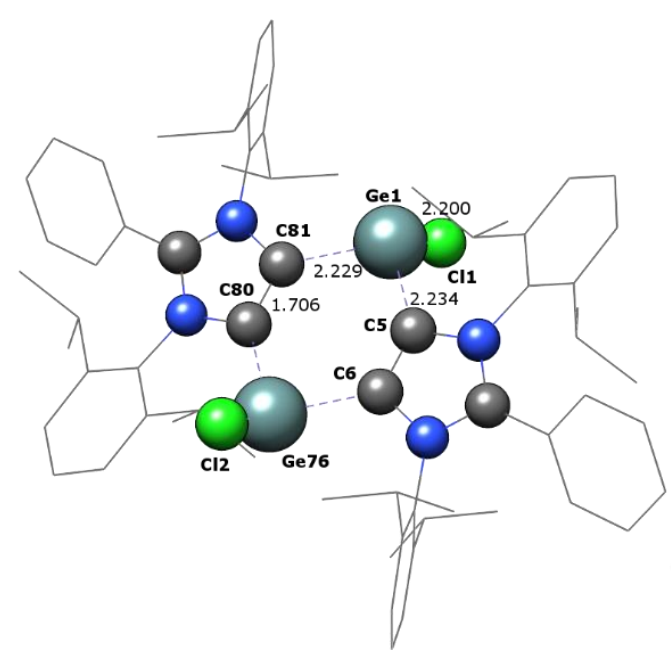

3

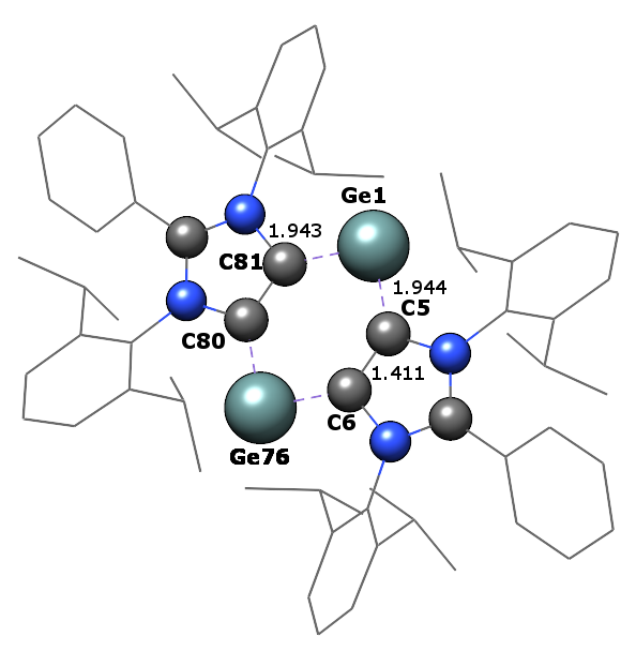

4

Figure S22. Optimized structures of $\mathbf{3}$ and $\mathbf{4}$ [along with the selected bond lengths $(\AA)$ ] at the B3LYP/6-31G(d) level of theory. Hydrogens atoms are omitted for clarity. 
Table S3. Summary of the calculated energies of 4 in gas phase for singlet $\left(4^{S}\right)$, triplet $\left(4^{\mathbf{T}}\right)$, and open shell singlet $\left(4^{\mathrm{OS}}\right)$ states at the B3LYP/def2TZVPP//6-31G(d) level of theory.

\begin{tabular}{|c|c|c|c|}
\hline & \multicolumn{3}{|c|}{ Electronic state } \\
\hline Energy / $E_{\mathrm{H}}$ & $\mathbf{4}^{\mathbf{S}}$ & $\mathbf{4}^{\mathbf{T}}$ & $\mathbf{4}^{\text {OS }}$ \\
\hline$E_{\mathrm{el} \mathrm{(B3LYP/def2-TZVPP)}}$ & -6933.988988 & -6933.969624 & -6933.988976 \\
\hline
\end{tabular}

Table S4. Natural population analysis (NPA) atomic charges of $\mathbf{3}$ and $\mathbf{4}$ calculated at the B3LYP/def2-TZVPP level of theory (see Figure S21 for atom numbering).

\begin{tabular}{|c|c|c|c|}
\hline Atom & $\mathbf{3}$ & $\mathbf{4}^{\mathbf{S}}$ & $\mathbf{4}^{\mathbf{T}}$ \\
\hline Ge1 & 0.78 & 0.42 & 0.53 \\
\hline Ge76 & 0.78 & 0.42 & 0.53 \\
\hline C5 & -0.24 & -0.32 & -0.28 \\
\hline C6 & -0.23 & -0.31 & -0.27 \\
\hline C80 & -0.24 & -0.32 & -0.28 \\
\hline C81 & -0.23 & -0.31 & -0.27 \\
\hline C11 & -0.60 & - & - \\
\hline
\end{tabular}

Table S5. Wiberg bond indices (WBIs) of 3 and $\mathbf{4}$ calculated at the B3LYP/def2-TZVPP level of theory (see Figure S21 for atom numbering).

\begin{tabular}{|c|c|c|c|}
\hline Bond & $\mathbf{3}$ & $\mathbf{4}^{\mathbf{S}}$ & $\mathbf{4}^{\mathbf{T}}$ \\
\hline Ge1-Ge76 & 0.00 & $0.27^{\mathrm{a}}$ & 0.02 \\
\hline Ge1-C5 & 0.68 & 0.95 & 0.80 \\
\hline Ge1-C81 & 0.68 & 0.93 & 0.79 \\
\hline Ge76-C6 & 0.68 & 0.93 & 0.79 \\
\hline Ge76-C80 & 0.68 & 0.95 & 0.80 \\
\hline Ge1-C11 & 0.53 & - & - \\
\hline \multicolumn{2}{|l}{} \\
aThe comparably high Ge1-Ge76 bond index may be an artifact of the antiferromagnetic coupling. \\
\hline
\end{tabular}

Table S6. Calculated NICS values for the central $\mathrm{C}_{4} \mathrm{Ge}_{2}$-ring of $\mathbf{4}$.

\begin{tabular}{|c|c|c|c|c|}
\hline & \multicolumn{2}{|c|}{ B3LYP/6-31G(d) } & \multicolumn{2}{c|}{ B3LYP-D3BJ/def2-TZVPP } \\
\hline Distance $(\AA)$ & $\mathbf{4}^{\mathrm{S}[\mathrm{a}]}$ & $\mathbf{4}^{\mathrm{T}}[\mathrm{a}]$ & $\mathbf{4}^{\mathrm{S}}[\mathrm{b}]$ & $\mathbf{4}^{\mathrm{T}}[\mathrm{b}]$ \\
\hline 0.0 & -4.5469 & 3.1895 & -19.1807 & -23.2783 \\
\hline 0.5 & -5.6186 & 1.9649 & -11.4869 & -17.4058 \\
\hline 1.0 & -6.3225 & -0.2532 & -6.3712 & -7.4594 \\
\hline 1.5 & -5.3098 & -0.3808 & -4.1031 & -2.5089 \\
\hline 2.0 & -3.8266 & -0.2917 & -2.7570 & -1.8000 \\
\hline 2.5 & -2.6185 & -0.3457 & -2.0676 & -2.5691 \\
\hline 3.0 & -1.7843 & -0.2917 & -1.7948 & -1.8000 \\
\hline
\end{tabular}



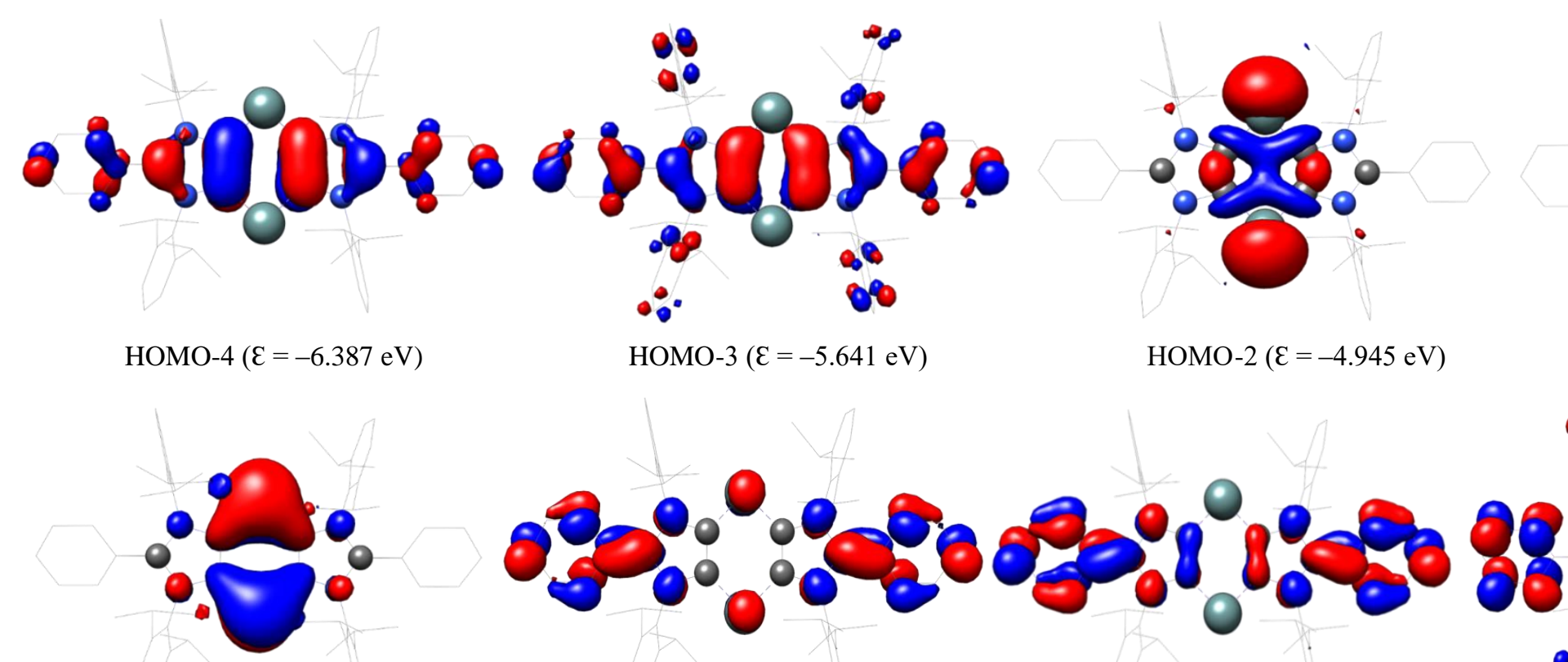

HOMO-2 $(\varepsilon=-4.945 \mathrm{eV})$

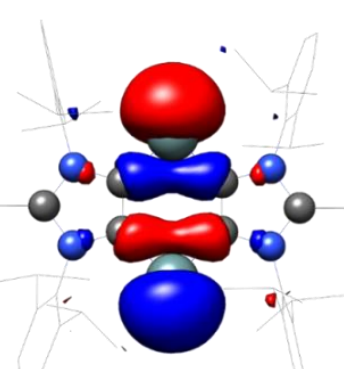

HOMO-1 $(\varepsilon=-4.751 \mathrm{eV})$

$\operatorname{HOMO}(\varepsilon=-3.010 \mathrm{eV})$

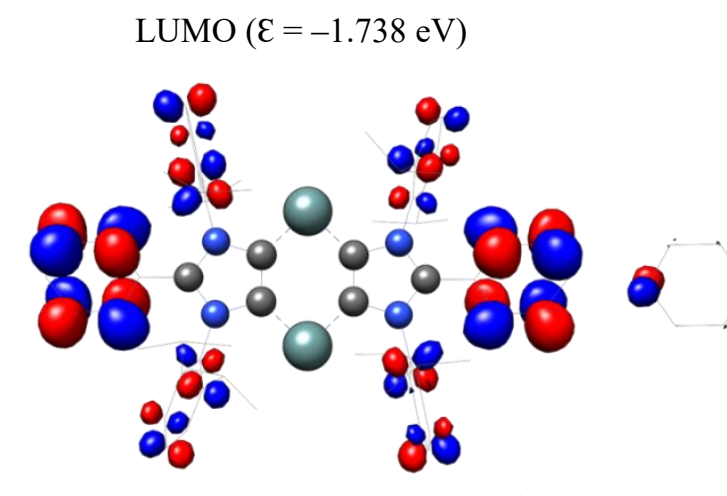

LUMO+1 $(\varepsilon=-1.387 \mathrm{eV})$
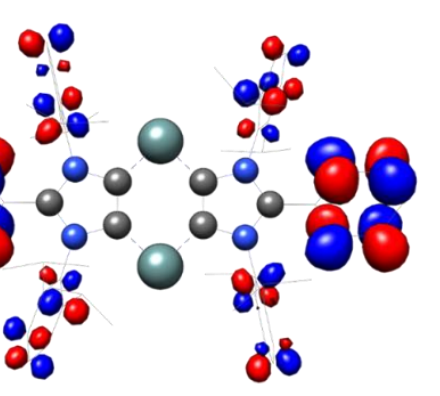

LUMO $+2(\varepsilon=-0.467 \mathrm{eV})$

LUMO $+3(\varepsilon=-0.727 \mathrm{eV})$

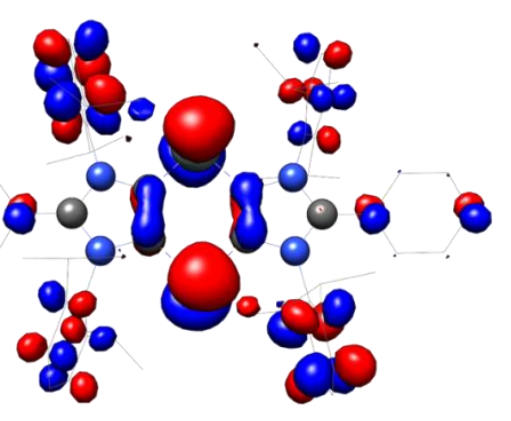

LUMO+4 ( $(\varepsilon=-0.467 \mathrm{eV})$

Figure S23. Selected molecular orbitals of compound $\left[\left(\mathrm{ADC}^{\mathrm{Ph}}\right) \mathrm{Ge}_{2}\left(4^{\mathrm{S}}\right)\right.$ calculated at the B3LYP/def2-TZVPP level of theory. The isovalue was arbitrarily chosen to be 0.03 . Hydrogen atoms were omitted for clarity. 


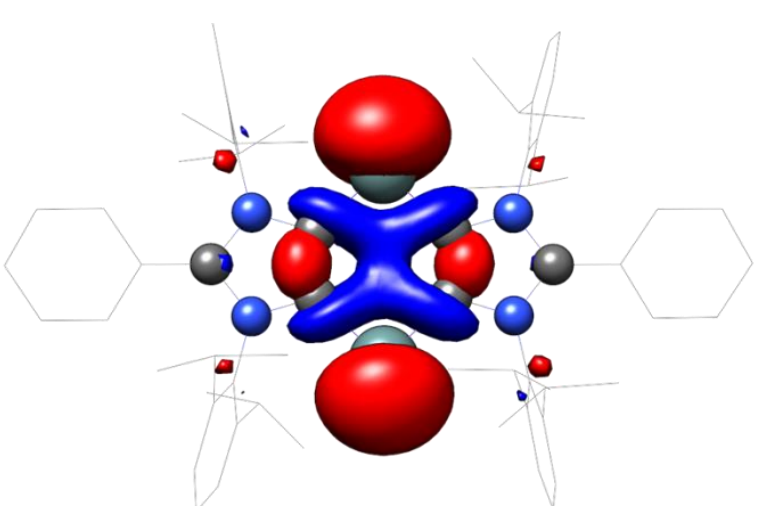

HOMO-2 $(\varepsilon=-5.339 \mathrm{eV})$

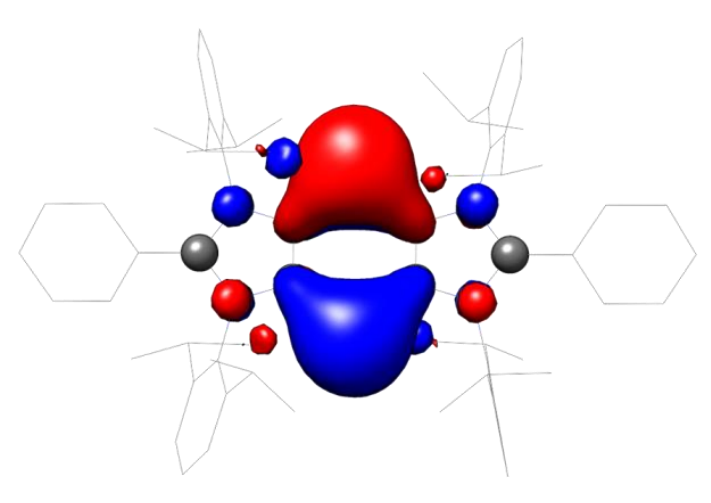

$\operatorname{SOMO}(\mathcal{E}=-2.582 \mathrm{eV})$

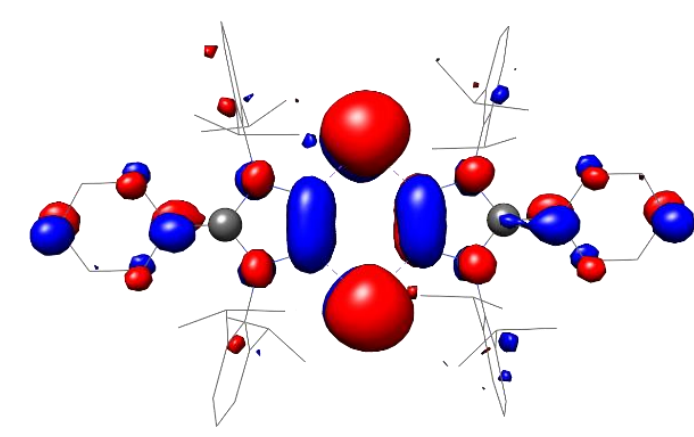

$\operatorname{LUMO}(\mathcal{E}=-0.926 \mathrm{eV})$

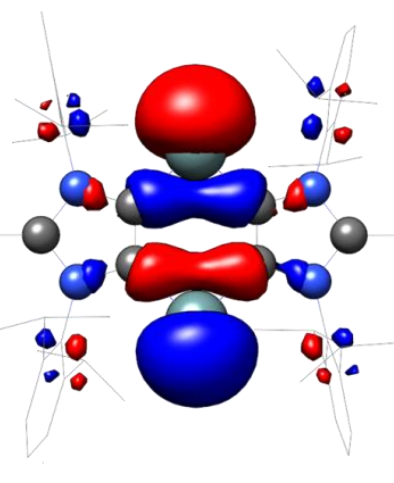

HOMO-1 $(\varepsilon=-3.945 \mathrm{eV})$

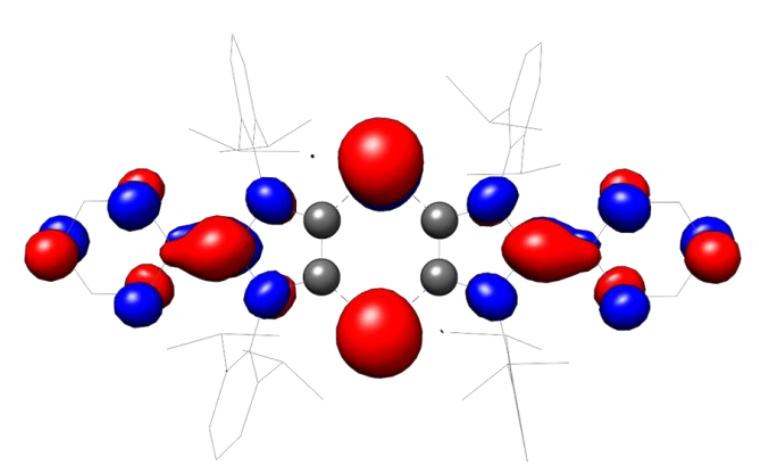

$\operatorname{SUMO}(\varepsilon=-1.539 \mathrm{eV})$

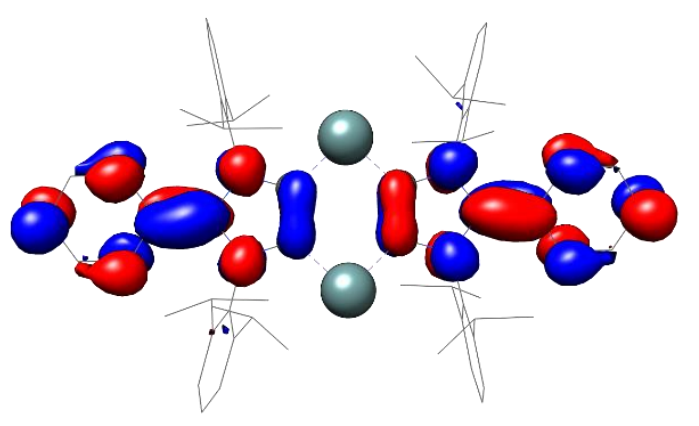

$\mathrm{LUMO}+1(\varepsilon=-0.623 \mathrm{eV})$

Figure S24. Selected molecular orbitals of compound $\left[\left(\mathrm{ADC}^{\mathrm{Ph}}\right) \mathrm{Ge}\right]_{2}\left(\mathbf{4}^{\mathbf{T}}\right)$ calculated at the B3LYP/def2-TZVPP level of theory. The isovalue was arbitrarily chosen to be 0.03 . Hydrogen atoms were omitted for clarity. 


\section{$\operatorname{CASSCF}(10,10)$ Calculations}

Table S7. Composition of the investigated active space. ${ }^{a}$

\begin{tabular}{|c|c|c|c|c|c|c|c|c|c|}
\hline & \multicolumn{2}{|r|}{ Singlet } & \multicolumn{2}{|r|}{ Triplet } & & 0.00 & 2221101100 & 0.00 & 2202101020 \\
\hline & $\mathrm{CI}$ & Symmetry & CI & Symmetry & & 0.00 & 1122210100 & 0.00 & 1122201100 \\
\hline \multirow{14}{*}{ GS } & 0.81 & 2222200000 & 0.69 & 2222110000 & & 0.00 & 1122110101 & 0.00 & 2222000110 \\
\hline & 0.04 & 2222010100 & 0.21 & 2222100100 & & 0.00 & 2221200010 & 0.00 & 2220101002 \\
\hline & 0.04 & 2222000200 & 0.01 & 2211110011 & & 0.00 & 2022110200 & 0.00 & 2221100020 \\
\hline & 0.01 & 2211200011 & 0.01 & 2212110100 & & 0.00 & 2212011010 & 0.00 & 1122101101 \\
\hline & 0.01 & 2221100110 & 0.01 & 2220110020 & \multirow{19}{*}{ ES 2} & & & 0.00 & 2212200010 \\
\hline & 0.01 & 2222020000 & 0.01 & 2221111000 & & 0.86 & 2222101000 & 0.67 & 2222100100 \\
\hline & 0.01 & 2212100101 & 0.01 & 2211210010 & & 0.02 & 2211101011 & 0.19 & 2222110000 \\
\hline & 0.01 & 2220200020 & 0.00 & 2211100111 & & 0.01 & 2221120000 & 0.01 & 2221111000 \\
\hline & 0.01 & 2212210000 & 0.00 & 2202110020 & & 0.01 & 2212111000 & 0.01 & 2211100111 \\
\hline & 0.01 & 2221201000 & 0.00 & 2221101100 & & 0.01 & 2222010010 & 0.01 & 2212110100 \\
\hline & 0.00 & 2212101010 & 0.00 & 2221010110 & & 0.01 & 2220101020 & 0.01 & 2222001010 \\
\hline & 0.00 & 2202200020 & & & & 0.01 & 2211201010 & 0.01 & 2221101100 \\
\hline & 0.00 & 2221110010 & & & & 0.01 & 2221102000 & 0.01 & 2220100120 \\
\hline & 0.00 & 2221101001 & & & & 0.01 & 2212101100 & 0.01 & 2221200010 \\
\hline \multirow{9}{*}{ ES 1} & 0.82 & 2222110000 & 0.86 & 2222101000 & & 0.01 & 2221001110 & 0.00 & 2211200110 \\
\hline & 0.04 & 2222100100 & 0.02 & 2221120000 & & 0.01 & 2221110100 & 0.00 & 2212120000 \\
\hline & 0.02 & 2221111000 & 0.01 & 2211101011 & & 0.00 & 2202101020 & 0.00 & 2212200001 \\
\hline & 0.01 & 2212120000 & 0.01 & 2212111000 & & 0.00 & 1122201100 & 0.00 & 2221100011 \\
\hline & 0.01 & 2211110011 & 0.01 & 2220101020 & & 0.00 & 2221100020 & 0.00 & 2202100120 \\
\hline & 0.01 & 2222001010 & 0.01 & 2211201010 & & 0.00 & 2220101002 & 0.00 & 2221010110 \\
\hline & 0.01 & 2220110020 & 0.01 & 2221110100 & & & & 0.00 & 2211110011 \\
\hline & 0.01 & 2211210010 & 0.01 & 2222010010 & & & & 0.00 & 1122210100 \\
\hline & 0.00 & 2202110020 & 0.01 & 2212101100 & & & & & \\
\hline
\end{tabular}

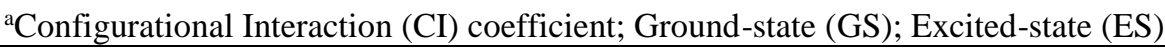

Table S8. CASSCF density-matrix. Orbitals 1-2 are the lone-pair orbitals, $3-5$ are the $\pi$ orbitals, 6-8 are considered as $\pi^{*}$ orbitals, and 9-10 are the $\pi^{*}$ orbitals of $\mathrm{ADC}^{\mathrm{Ph}}$ backbone. The number represents the occupation.

\begin{tabular}{r|rrrrrrrrrr} 
Orbitals & 1 & 2 & 3 & 4 & 5 & 6 & 7 & 8 & 9 & 10 \\
\hline 1 & 1.99 & 0.00 & 0.00 & 0.00 & 0.00 & 0.00 & 0.00 & 0.00 & 0.00 & 0.00 \\
2 & 0.00 & 1.99 & 0.00 & 0.00 & 0.00 & 0.00 & 0.00 & 0.00 & 0.00 & 0.00 \\
3 & 0.00 & 0.00 & 1.93 & 0.00 & 0.00 & 0.00 & 0.00 & 0.00 & 0.00 & 0.00 \\
4 & 0.00 & 0.00 & 0.00 & 1.91 & 0.00 & 0.00 & 0.00 & 0.00 & 0.00 & 0.00 \\
5 & 0.00 & 0.00 & 0.00 & 0.00 & 1.13 & 0.00 & 0.00 & 0.00 & 0.00 & 0.00 \\
6 & 0.00 & 0.00 & 0.00 & 0.00 & 0.00 & 0.37 & 0.00 & 0.00 & 0.00 & 0.00 \\
7 & 0.00 & 0.00 & 0.00 & 0.00 & 0.00 & 0.00 & 0.34 & 0.00 & 0.00 & 0.00 \\
8 & 0.00 & 0.00 & 0.00 & 0.00 & 0.00 & 0.00 & 0.00 & 0.23 & 0.00 & 0.00 \\
9 & 0.00 & 0.00 & 0.00 & 0.00 & 0.00 & 0.00 & 0.00 & 0.00 & 0.08 & 0.00 \\
10 & 0.00 & 0.00 & 0.00 & 0.00 & 0.00 & 0.00 & 0.00 & 0.00 & 0.00 & 0.04 \\
\hline
\end{tabular}


Table S9. CASSCF energies of different states (in ascending energy values).

\begin{tabular}{|c|c|c|c|c|}
\hline State & Ms & E/a.u. & $\Delta E_{S O-E \#} / \mathrm{kcal} \mathrm{mol}^{-1}$ & $\Delta E / \mathrm{nm}$ \\
\hline $\mathrm{S}_{0}$ & 1 & 0 & 0 & 0 \\
\hline $\mathrm{T}_{0}$ & 3 & 0.027294 & 17.1 & 1669 \\
\hline $\mathrm{S}_{1}$ & 1 & 0.053644 & 33.7 & 849 \\
\hline $\mathrm{T}_{1}$ & 3 & 0.064595 & 40.6 & 701 \\
\hline $\mathrm{S}_{2}$ & 1 & 0.066442 & 41.8 & 686 \\
\hline $\mathrm{T}_{2}$ & 3 & 0.076957 & 48.4 & 592 \\
\hline
\end{tabular}

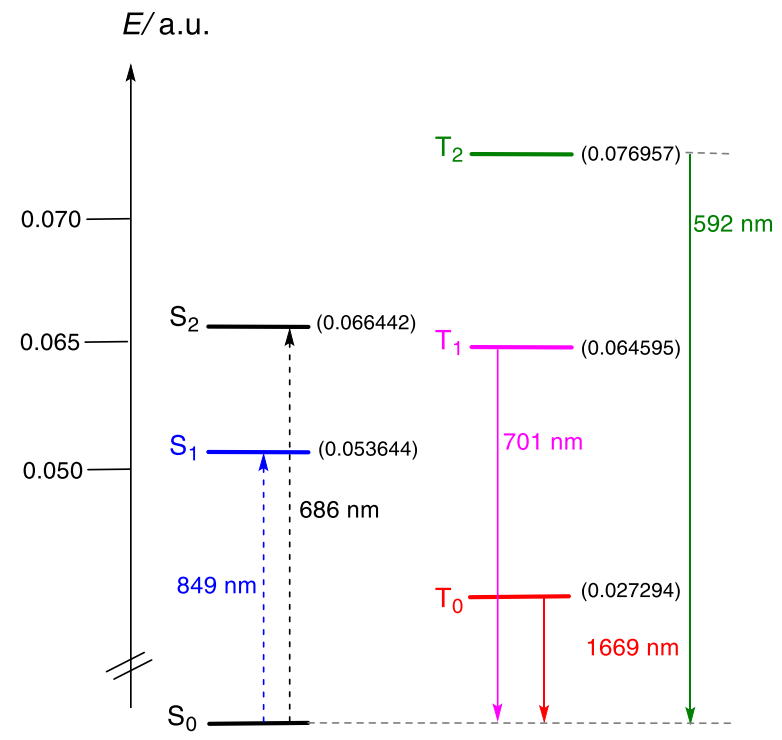

Figure S25. Simplified schematic representation of electronic states and energies of $\mathbf{4}$. 
Table S10. CASSCF Spin-density-matrix. Orbitals 1-2 are the lone-pair orbitals, 3-5 are the $\pi$ orbitals, 6-8 are considered as $\pi^{*}$ orbitals, and 9-10 are the $\pi^{*}$ orbitals of the $\mathrm{ADC}^{\mathrm{Ph}}$ backbone.

\begin{tabular}{rr|rrrrrrrrrr} 
Orbitals & 1 & 2 & 3 & 4 & 5 & 6 & 7 & 8 & 9 & 10 \\
\hline & 1 & 0.00 & 0.00 & 0.00 & 0.00 & 0.00 & 0.00 & 0.00 & 0.00 & 0.00 & 0.00 \\
& 2 & 0.00 & 0.00 & 0.00 & 0.00 & 0.00 & 0.00 & 0.00 & 0.00 & 0.00 & 0.00 \\
& 3 & 0.00 & 0.00 & 0.01 & 0.00 & 0.00 & 0.01 & 0.00 & -0.04 & 0.00 & 0.00 \\
& 4 & 0.00 & 0.00 & 0.00 & 0.01 & 0.00 & 0.00 & -0.01 & 0.00 & 0.00 & 0.00 \\
& 5 & 0.00 & 0.00 & 0.00 & 0.00 & 0.47 & 0.00 & 0.00 & 0.00 & 0.00 & -0.02 \\
& 6 & 0.00 & 0.00 & 0.01 & 0.00 & 0.00 & 0.16 & 0.00 & 0.00 & 0.00 & 0.00 \\
7 & 0.00 & 0.00 & 0.00 & -0.01 & 0.00 & 0.00 & 0.16 & 0.00 & 0.00 & 0.00 \\
8 & 0.00 & 0.00 & -0.04 & 0.00 & 0.00 & 0.00 & 0.00 & 0.16 & 0.00 & 0.00 \\
9 & 0.00 & 0.00 & 0.00 & 0.00 & 0.00 & 0.00 & 0.00 & 0.00 & 0.01 & 0.00 \\
10 & 0.00 & 0.00 & 0.00 & 0.00 & -0.02 & 0.00 & 0.00 & 0.00 & 0.00 & 0.01 \\
\hline
\end{tabular}

\section{Diradical character of the compound 4}

Table S11: Diradical character of compound 4. ${ }^{[19]}$

UB3LYP/6-31G(d) CASSCF(10,10)/def2-TZVPP

$\gamma_{\mathrm{i}} \quad 0.32$




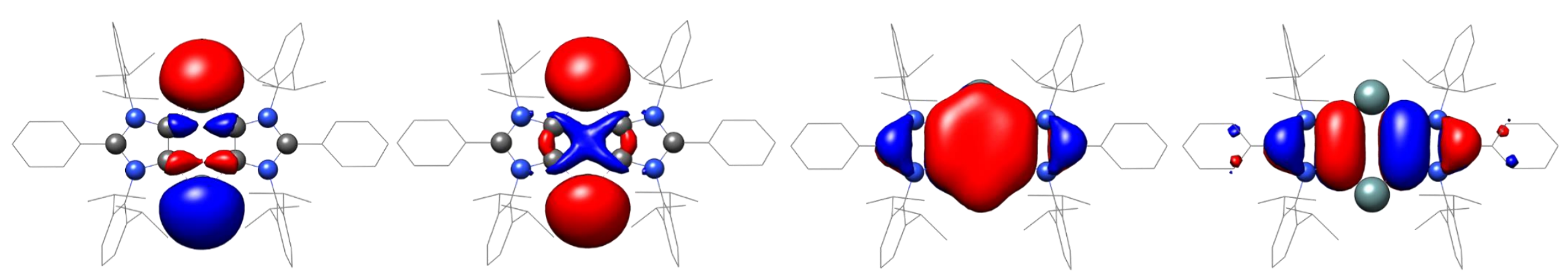

HOMO-4

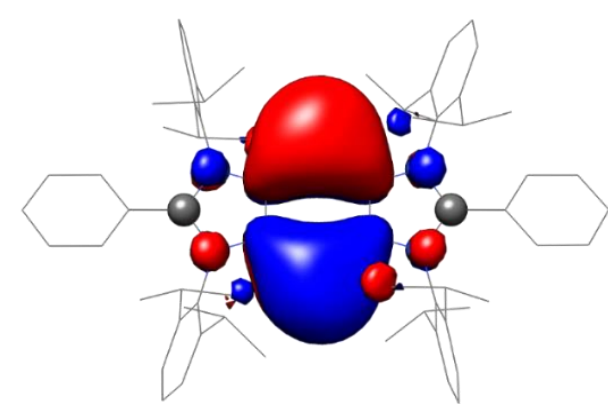

HOMO

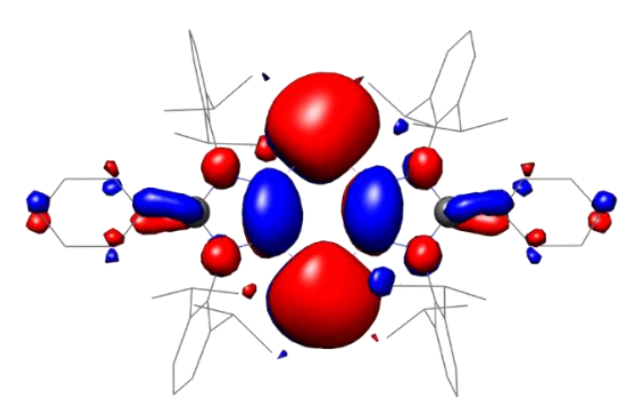

$\mathrm{LUMO}+2$
HOMO-3

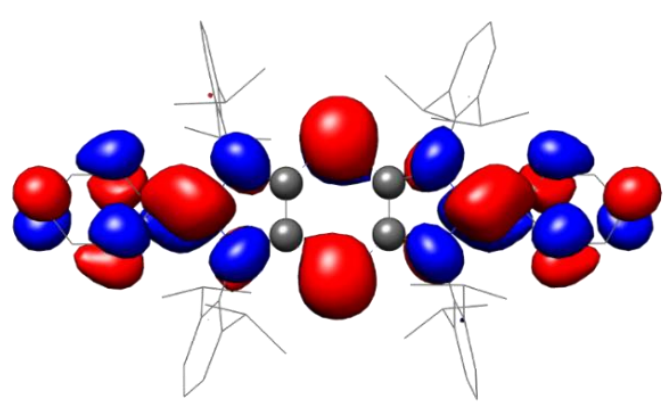

LUMO

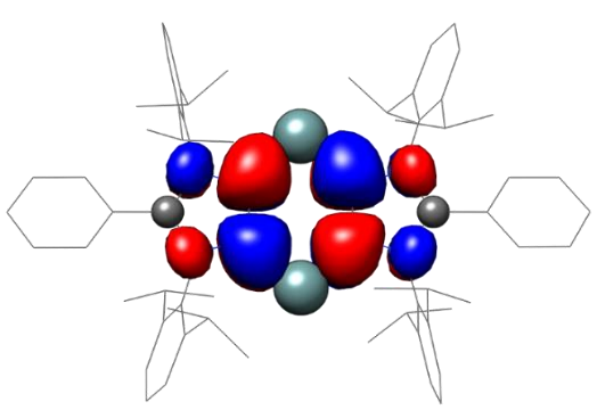

$\mathrm{LUMO}+3$
HOMO-2

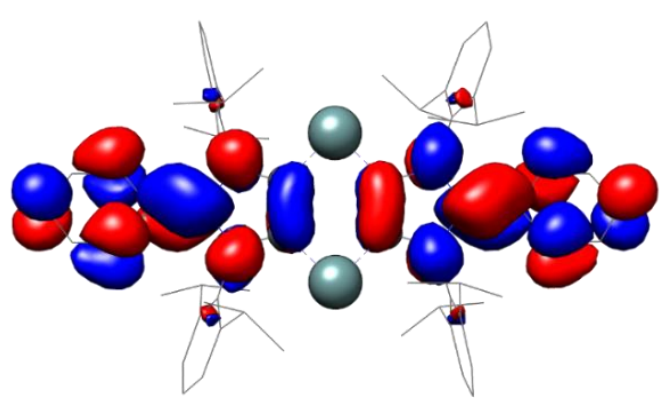

LUMO+1

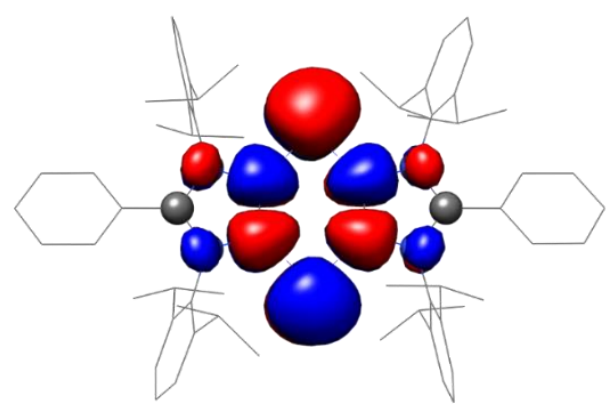

$\mathrm{LUMO}+4$

Figure S26. Optimized CASSCF $(10,10)$ orbitals. 


\section{Thermodynamics}

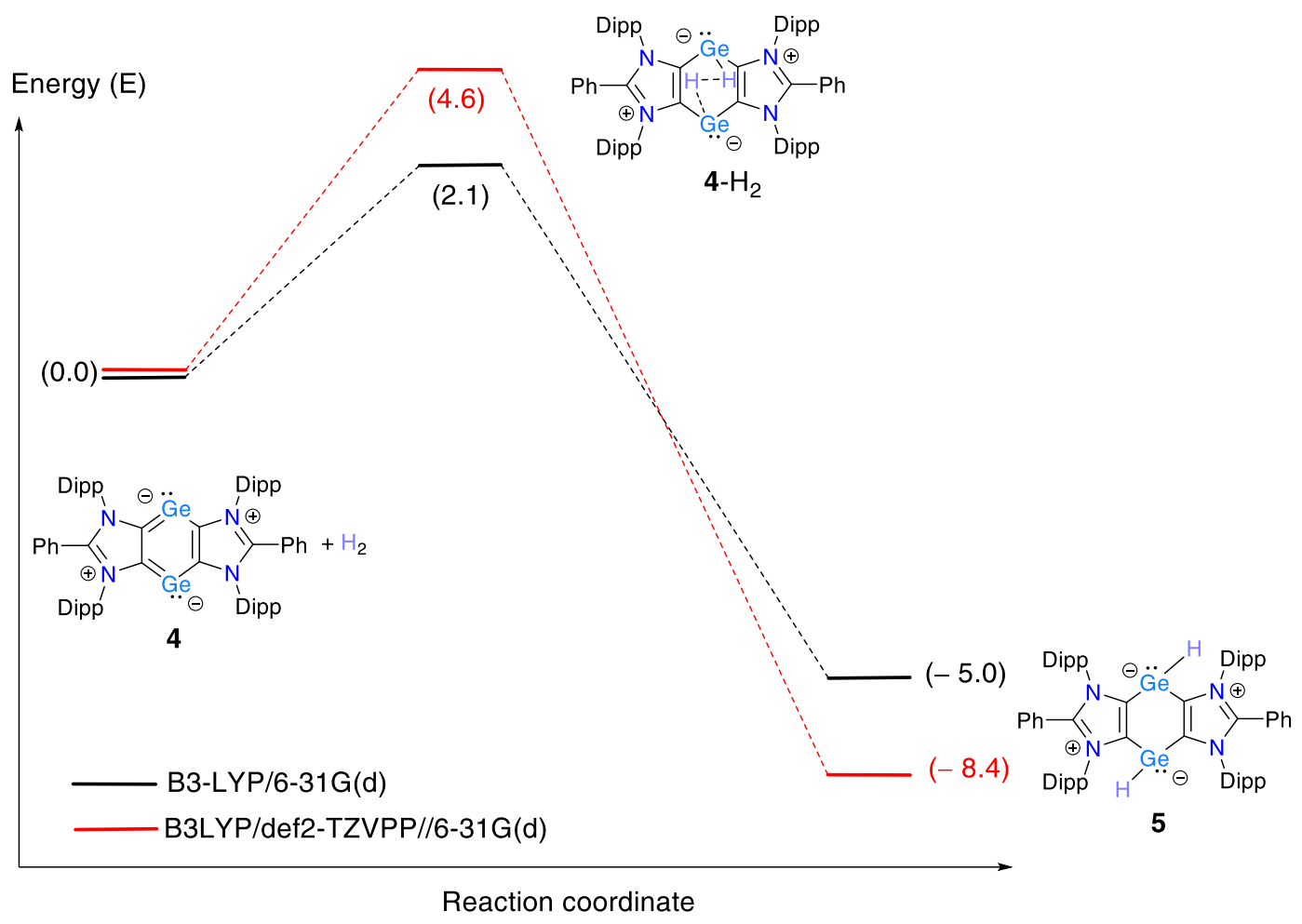

Figure S27. Calculated Gibbs free energies of the reaction of dihydrogen with $\mathbf{4}$ to $\mathbf{5}$ at the B3-LYP/6-31G(d) and B3LYP/def2-TZVPP//6-31G(d) levels of theory.

\section{NMR Calculations}

The absolute isotropic shielding $(\sigma)$ values were calculated using B3LYP/def2-TZVPP level of theory within the Gaussian16 software suite. ${ }^{[23]}$ The absolute isotropic chemical shifts were referenced against tetramethylsilane $\left(\mathrm{Me}_{4} \mathrm{Si}\right)$. The chemical shift $(\delta)$ was calculated by $\delta_{\text {substance }}=\sigma_{\text {reference }}-\sigma_{\text {substance }}$ and is given in ppm (Table S12). The influence of the solvent was treated with the Polarized Continuum Model (PCM) (benzene $\varepsilon=2.2706$; THF $\varepsilon=$ 7.4257). ${ }^{[24]}$ 
Table S12. Calculated ${ }^{1} \mathrm{H}$ NMR chemical shifts for the Ge-H units of 5 .

\begin{tabular}{|c|c|c|}
\hline Method & trans / ppm & cis / ppm \\
\hline B3LYP/6-31G(d) (gas) & 4.24 & 3.62 \\
\hline B3LYP/def2-TZVPP (THF) & 4.13 & 3.60 \\
\hline B3LYP/def2-TZVPP(C $\left.6 \mathrm{H}_{6}\right)$ & 4.22 & 3.56 \\
\hline
\end{tabular}

\section{TD-DFT Calculations}

TD-DFT calculations for compound 4 were performed using the Gaussian16 software package. $^{[25]}$ Single point PCM[TD-B3LYP+D3(BJ)/def2-TZVPP] calculations were performed to estimate the change in the UV-visible spectra profiles of $\mathbf{4}$ in the presence of THF solvent. Only the first 10 vertical excitations were taken into account.

Table S13. Wavelength $(\lambda)$, oscillator strength $(f)$, and main assignments of the TD$\mathrm{DFT} /[\mathrm{B} 3 \mathrm{LYP}+\mathrm{D} 3(\mathrm{BJ}) / \mathrm{def} 2-\mathrm{TZVPP}]$ results of 4. Threshold for printing excitations was chosen to be $f \geq 0.02$.

\begin{tabular}{|c|c|c|c|}
\hline state & $\lambda / \mathrm{nm}$ & $f$ & Assignment \\
\hline 1 & 1526 & 0.01042 & $\mathrm{H}>\mathrm{L}(c=0.978300)$ \\
\hline 4 & 690 & 0.00216 & $\mathrm{H}->\mathrm{L}+2(c=0.925028)$ \\
\hline 6 & 607 & 0.0334 & $\mathrm{H}->\mathrm{L}+4(c=0.284751)$ \\
\hline 7 & 597 & 0.036 & $\mathrm{H}->\mathrm{L}+4(c=0.271793)$ \\
\hline 8 & 605 & 0.004 & $\mathrm{H}->\mathrm{L}+5(c=0.358781)$ \\
& & & $\mathrm{H}->\mathrm{L}+7(c=0.478438)$ \\
\hline 9 & 584 & 0.02 & $\mathrm{H}>\mathrm{L}+4(c=0.104643)$ \\
& & & $\mathrm{H}>\mathrm{H}+8(c=0.572159)$ \\
& & & \\
\hline
\end{tabular}




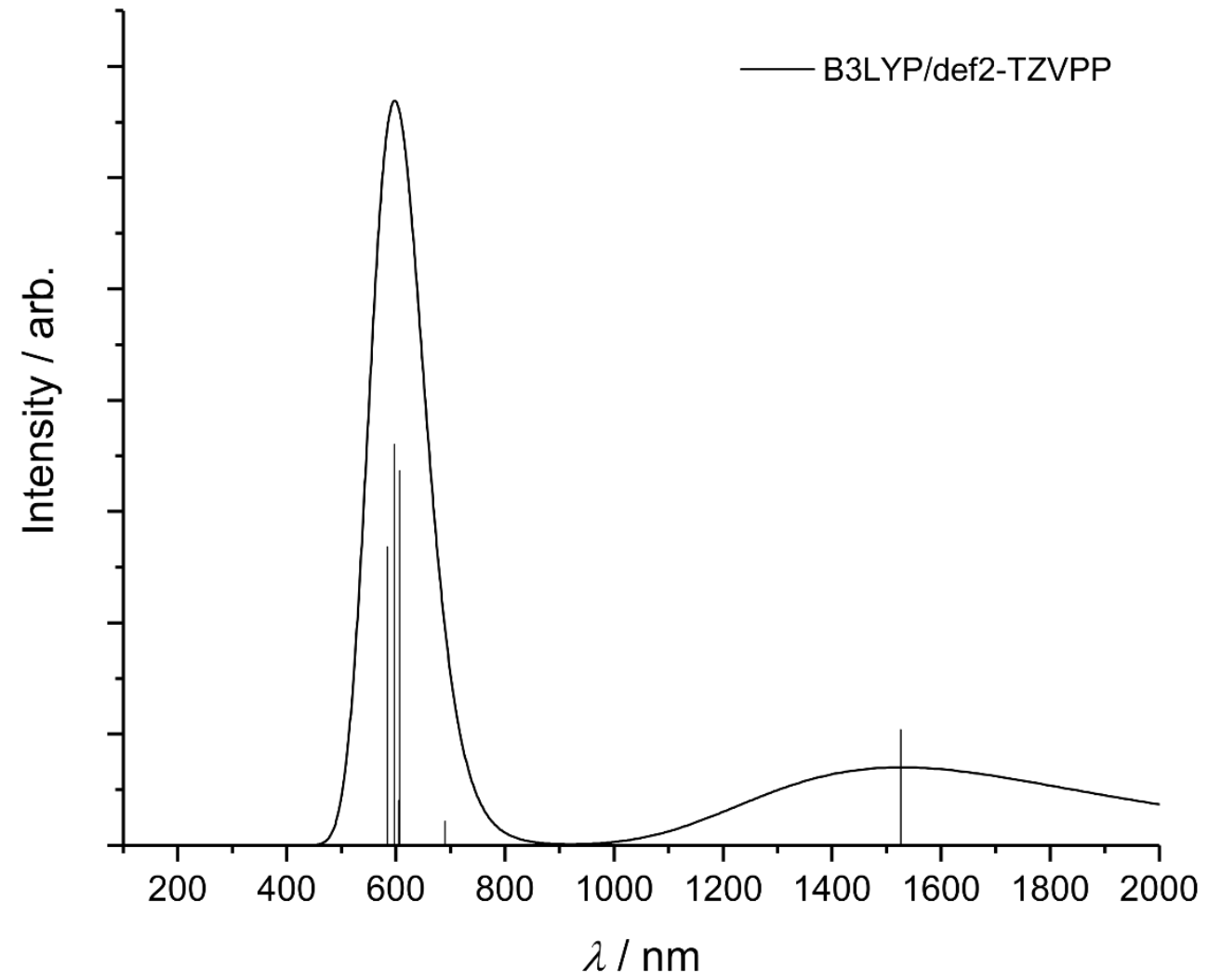

Figure S28: UV/vis spectrum of 4 calculated at the PCM[TD-B3LYP+D3(BJ)/def2-TZVPP] level of theory. The standard deviation was arbitrarily set to $0.4 \mathrm{eV}$. 


\section{Cartesian Coordinates for the Optimized Geometries of 3 and 4}

\section{Compound $\left[\left(\mathrm{ADC}^{\mathrm{Ph}}\right) \mathrm{GeCl}\right]_{2}(\mathbf{3})$}

$E_{\mathrm{B} 3 \mathrm{LYP}(\mathrm{D} 3 \mathrm{BJ}) / 6-31 \mathrm{G}(\mathrm{d})}=-7850.619320 E_{\mathrm{H}}$

\begin{tabular}{|c|c|c|c|}
\hline $\mathrm{Ge}$ & -0.05092 & -2.04679 & -0.2959 \\
\hline $\mathrm{N}$ & -2.85072 & -1.03876 & 0.1475 \\
\hline $\mathrm{N}$ & -2.78338 & 1.14601 & 0.12725 \\
\hline $\mathrm{C}$ & -3.64418 & 0.08143 & 0.17662 \\
\hline $\mathrm{C}$ & -1.48682 & -0.67507 & 0.08711 \\
\hline $\mathrm{C}$ & -1.44495 & 0.69827 & 0.11455 \\
\hline $\mathrm{C}$ & -3.32103 & -2.41617 & 0.18263 \\
\hline $\mathrm{C}$ & -3.96035 & -2.96649 & -0.94997 \\
\hline $\mathrm{C}$ & -4.49191 & -4.26281 & -0.82969 \\
\hline $\mathrm{H}$ & -4.99243 & -4.70717 & -1.68288 \\
\hline $\mathrm{C}$ & -4.37814 & -4.98485 & 0.35405 \\
\hline $\mathrm{H}$ & -4.80127 & -5.98197 & 0.42621 \\
\hline $\mathrm{C}$ & -3.69364 & -4.43869 & 1.44239 \\
\hline $\mathrm{H}$ & -3.57861 & -5.02789 & 2.34345 \\
\hline $\mathrm{C}$ & -3.14196 & -3.15109 & 1.38514 \\
\hline $\mathrm{C}$ & -4.0675 & -2.25445 & -2.2994 \\
\hline $\mathrm{H}$ & -3.54728 & -1.29401 & -2.22621 \\
\hline $\mathrm{C}$ & -3.35029 & -3.06502 & -3.40567 \\
\hline $\mathrm{H}$ & -2.29806 & -3.21615 & -3.15576 \\
\hline $\mathrm{H}$ & -3.39024 & -2.51505 & -4.35295 \\
\hline $\mathrm{H}$ & -3.82981 & -4.0394 & -3.56002 \\
\hline $\mathrm{C}$ & -5.53855 & -1.98683 & -2.69856 \\
\hline $\mathrm{H}$ & -6.08161 & -2.92844 & -2.84623 \\
\hline $\mathrm{H}$ & -5.57339 & -1.4335 & -3.64459 \\
\hline $\mathrm{H}$ & -6.07155 & -1.40513 & -1.94131 \\
\hline $\mathrm{C}$ & -2.36138 & -2.58801 & 2.5802 \\
\hline $\mathrm{H}$ & -1.55967 & -1.96561 & 2.1717 \\
\hline $\mathrm{C}$ & -1.69233 & -3.69108 & 3.42546 \\
\hline $\mathrm{H}$ & -2.42924 & -4.28919 & 3.97524 \\
\hline $\mathrm{H}$ & -1.03212 & -3.22979 & 4.1666 \\
\hline $\mathrm{H}$ & -1.09348 & -4.36418 & 2.80327 \\
\hline $\mathrm{C}$ & -3.2214 & -1.68455 & 3.49738 \\
\hline $\mathrm{H}$ & -3.6167 & -0.81231 & 2.96946 \\
\hline $\mathrm{H}$ & -2.61011 & -1.31245 & 4.32671 \\
\hline $\mathrm{H}$ & -4.06466 & -2.24676 & 3.91883 \\
\hline $\mathrm{C}$ & -3.12684 & 2.5493 & -0.05334 \\
\hline $\mathrm{C}$ & -3.26329 & 3.02154 & -1.3838 \\
\hline $\mathrm{C}$ & -3.58179 & 4.37516 & -1.55891 \\
\hline $\mathrm{H}$ & -3.69479 & 4.77238 & -2.56071 \\
\hline $\mathrm{C}$ & -3.75815 & 5.22129 & -0.4607 \\
\hline $\mathrm{H}$ & -4.00987 & 6.26546 & -0.6188 \\
\hline
\end{tabular}




\begin{tabular}{|c|c|c|c|}
\hline $\mathrm{C}$ & -3.59926 & 4.73267 & 0.83388 \\
\hline $\mathrm{H}$ & -3.721 & 5.40241 & 1.67723 \\
\hline $\mathrm{C}$ & -3.26528 & 3.38736 & 1.06989 \\
\hline $\mathrm{C}$ & -3.03982 & 2.1047 & -2.5916 \\
\hline $\mathrm{H}$ & -3.29921 & 1.08166 & -2.29435 \\
\hline $\mathrm{C}$ & -1.5459 & 2.08849 & -2.9926 \\
\hline $\mathrm{H}$ & -1.23168 & 3.08346 & -3.32643 \\
\hline $\mathrm{H}$ & -1.36502 & 1.36114 & -3.78932 \\
\hline $\mathrm{H}$ & -0.93191 & 1.78991 & -2.14135 \\
\hline $\mathrm{C}$ & -3.92225 & 2.45678 & -3.80688 \\
\hline $\mathrm{H}$ & -4.98459 & 2.51003 & -3.54111 \\
\hline $\mathrm{H}$ & -3.80267 & 1.68938 & -4.57943 \\
\hline $\mathrm{H}$ & -3.63557 & 3.41543 & -4.2548 \\
\hline $\mathrm{C}$ & -3.05994 & 2.88373 & 2.49662 \\
\hline $\mathrm{H}$ & -2.50325 & 1.94351 & 2.44469 \\
\hline $\mathrm{C}$ & -2.19817 & 3.85202 & 3.33528 \\
\hline $\mathrm{H}$ & -1.24985 & 4.0577 & 2.83212 \\
\hline $\mathrm{H}$ & -1.96541 & 3.39178 & 4.30075 \\
\hline $\mathrm{H}$ & -2.7152 & 4.80036 & 3.52755 \\
\hline $\mathrm{C}$ & -4.41556 & 2.6155 & 3.19416 \\
\hline $\mathrm{H}$ & -4.99644 & 3.54224 & 3.28491 \\
\hline $\mathrm{H}$ & -4.24738 & 2.222 & 4.20358 \\
\hline $\mathrm{H}$ & -5.02333 & 1.89168 & 2.641 \\
\hline $\mathrm{C}$ & -5.11461 & 0.12602 & 0.2724 \\
\hline $\mathrm{C}$ & -5.86809 & 1.10314 & -0.41503 \\
\hline $\mathrm{H}$ & -5.37501 & 1.83233 & -1.03939 \\
\hline $\mathrm{C}$ & -7.26024 & 1.14042 & -0.30836 \\
\hline $\mathrm{H}$ & -7.81301 & 1.90069 & -0.85023 \\
\hline $\mathrm{C}$ & -7.93791 & 0.20669 & 0.48178 \\
\hline $\mathrm{H}$ & -9.01947 & 0.23807 & 0.56238 \\
\hline $\mathrm{C}$ & -7.20567 & -0.76882 & 1.16643 \\
\hline $\mathrm{H}$ & -7.71509 & -1.49953 & 1.78582 \\
\hline $\mathrm{C}$ & -5.81391 & -0.81181 & 1.06533 \\
\hline $\mathrm{H}$ & -5.27525 & -1.57389 & 1.60808 \\
\hline $\mathrm{Ge}$ & 0.05092 & 2.04679 & 0.2959 \\
\hline $\mathrm{N}$ & 2.85072 & 1.03876 & -0.14749 \\
\hline $\mathrm{N}$ & 2.78338 & -1.14601 & -0.12727 \\
\hline $\mathrm{C}$ & 3.64418 & -0.08143 & -0.17663 \\
\hline $\mathrm{C}$ & 1.48682 & 0.67507 & -0.08711 \\
\hline $\mathrm{C}$ & 1.44495 & -0.69827 & -0.11456 \\
\hline $\mathrm{C}$ & 3.32103 & 2.41617 & -0.18261 \\
\hline $\mathrm{C}$ & 3.96035 & 2.96648 & 0.95 \\
\hline $\mathrm{C}$ & 4.4919 & 4.2628 & 0.82974 \\
\hline $\mathrm{H}$ & 4.99242 & 4.70715 & 1.68294 \\
\hline $\mathrm{C}$ & 4.37814 & 4.98485 & -0.35399 \\
\hline $\mathrm{H}$ & 4.80127 & 5.98197 & -0.42614 \\
\hline
\end{tabular}




\begin{tabular}{|c|c|c|c|}
\hline $\mathrm{C}$ & 3.69364 & 4.43871 & -1.44234 \\
\hline $\mathrm{H}$ & 3.57862 & 5.02792 & -2.34339 \\
\hline $\mathrm{C}$ & 3.14197 & 3.1511 & -1.3851 \\
\hline $\mathrm{C}$ & 4.06749 & 2.25442 & 2.29942 \\
\hline $\mathrm{H}$ & 3.54726 & 1.29398 & 2.22622 \\
\hline $\mathrm{C}$ & 3.35028 & 3.06499 & 3.4057 \\
\hline $\mathrm{H}$ & 2.29806 & 3.21612 & 3.15579 \\
\hline $\mathrm{H}$ & 3.39023 & 2.515 & 4.35297 \\
\hline $\mathrm{H}$ & 3.82981 & 4.03936 & 3.56007 \\
\hline $\mathrm{C}$ & 5.53853 & 1.98679 & 2.69858 \\
\hline $\mathrm{H}$ & 6.0816 & 2.92839 & 2.84626 \\
\hline $\mathrm{H}$ & 5.57338 & 1.43345 & 3.64461 \\
\hline $\mathrm{H}$ & 6.07153 & 1.40509 & 1.94133 \\
\hline $\mathrm{C}$ & 2.36139 & 2.58804 & -2.58018 \\
\hline $\mathrm{H}$ & 1.5597 & 1.96562 & -2.17169 \\
\hline $\mathrm{C}$ & 1.69232 & 3.69112 & -3.42542 \\
\hline $\mathrm{H}$ & 2.42923 & 4.28926 & -3.97518 \\
\hline $\mathrm{H}$ & 1.03212 & 3.22984 & -4.16656 \\
\hline $\mathrm{H}$ & 1.09346 & 4.36419 & -2.80321 \\
\hline $\mathrm{C}$ & 3.22143 & 1.68462 & -3.49738 \\
\hline $\mathrm{H}$ & 3.61674 & 0.81237 & -2.96948 \\
\hline $\mathrm{H}$ & 2.61015 & 1.31253 & -4.32673 \\
\hline $\mathrm{H}$ & 4.06468 & 2.24685 & -3.91881 \\
\hline $\mathrm{C}$ & 3.12683 & -2.5493 & 0.05331 \\
\hline $\mathrm{C}$ & 3.26329 & -3.02156 & 1.38378 \\
\hline $\mathrm{C}$ & 3.58178 & -4.37518 & 1.55887 \\
\hline $\mathrm{H}$ & 3.69478 & -4.7724 & 2.56066 \\
\hline $\mathrm{C}$ & 3.75814 & -5.2213 & 0.46074 \\
\hline $\mathrm{H}$ & 4.00985 & -6.26547 & 0.61876 \\
\hline $\mathrm{C}$ & 3.59925 & -4.73267 & -0.83392 \\
\hline $\mathrm{H}$ & 3.72098 & -5.4024 & -1.67728 \\
\hline $\mathrm{C}$ & 3.26527 & -3.38735 & -1.06993 \\
\hline $\mathrm{C}$ & 3.03983 & -2.10472 & 2.59158 \\
\hline $\mathrm{H}$ & 3.29923 & -1.08168 & 2.29433 \\
\hline $\mathrm{C}$ & 1.54591 & -2.08851 & 2.99259 \\
\hline $\mathrm{H}$ & 1.23169 & -3.08348 & 3.32641 \\
\hline $\mathrm{H}$ & 1.36504 & -1.36116 & 3.78932 \\
\hline $\mathrm{H}$ & 0.93192 & -1.78991 & 2.14134 \\
\hline $\mathrm{C}$ & 3.92226 & -2.45682 & 3.80685 \\
\hline $\mathrm{H}$ & 4.9846 & -2.51007 & 3.54107 \\
\hline $\mathrm{H}$ & 3.8027 & -1.68942 & 4.57941 \\
\hline $\mathrm{H}$ & 3.63558 & -3.41547 & 4.25476 \\
\hline $\mathrm{C}$ & 3.05994 & -2.88371 & -2.49665 \\
\hline $\mathrm{H}$ & 2.50325 & -1.9435 & -2.44471 \\
\hline $\mathrm{C}$ & 2.19818 & -3.852 & -3.33532 \\
\hline $\mathrm{H}$ & 1.24985 & -4.05768 & -2.83216 \\
\hline
\end{tabular}




$\begin{array}{lrrr}\mathrm{H} & 1.96542 & -3.39175 & -4.30078 \\ \mathrm{H} & 2.71522 & -4.80034 & -3.5276 \\ \mathrm{C} & 4.41557 & -2.61548 & -3.19418 \\ \mathrm{H} & 4.99645 & -3.54222 & -3.28494 \\ \mathrm{H} & 4.24738 & -2.22197 & -4.2036 \\ \mathrm{H} & 5.02333 & -1.89166 & -2.64101 \\ \mathrm{C} & 5.11461 & -0.12602 & -0.2724 \\ \mathrm{C} & 5.86809 & -1.10315 & 0.415 \\ \mathrm{H} & 5.37501 & -1.83236 & 1.03934 \\ \mathrm{C} & 7.26024 & -1.14043 & 0.30833 \\ \mathrm{H} & 7.81301 & -1.90072 & 0.85018 \\ \mathrm{C} & 7.93791 & -0.20669 & -0.48179 \\ \mathrm{H} & 9.01947 & -0.23807 & -0.56239 \\ \mathrm{C} & 7.20567 & 0.76884 & -1.16641 \\ \mathrm{H} & 7.71509 & 1.49956 & -1.78579 \\ \mathrm{C} & 5.81391 & 0.81183 & -1.06532 \\ \mathrm{H} & 5.27525 & 1.57392 & -1.60805 \\ \mathrm{Cl} & -0.25366 & -1.35021 & -2.71784 \\ \mathrm{Cl} & 0.25365 & 1.3502 & 2.71785\end{array}$

\section{Compound $\left[\left(\mathrm{ADC}^{\mathrm{Ph}}\right) \mathrm{Ge}\right]_{2}\left(\mathbf{4}^{\mathrm{S}}\right)$}

$E_{\mathrm{B} 3 \mathrm{LYP}(\mathrm{D} 3 \mathrm{BJ}) / 6-31 \mathrm{G}(\mathrm{d})}=-6931.486970 E_{\mathrm{H}}$

$\begin{array}{lrrr}\mathrm{Ge} & -1.17449 & -1.23953 & -1.13056 \\ \mathrm{~N} & 0.78377 & 0.07862 & -2.88908 \\ \mathrm{~N} & 2.09752 & 1.31835 & -1.65552 \\ \mathrm{C} & 1.85482 & 0.92651 & -2.93739 \\ \mathrm{C} & 0.3077 & -0.06661 & -1.54184 \\ \mathrm{C} & 1.13195 & 0.76379 & -0.7534 \\ \mathrm{C} & 0.28297 & -0.71843 & -3.99441 \\ \mathrm{C} & 1.05986 & -1.81569 & -4.44338 \\ \mathrm{C} & 0.59016 & -2.53985 & -5.54936 \\ \mathrm{H} & 1.1643 & -3.38126 & -5.91856 \\ \mathrm{C} & -0.60459 & -2.19695 & -6.18278 \\ \mathrm{H} & -0.94426 & -2.76435 & -7.04382 \\ \mathrm{C} & -1.37211 & -1.14025 & -5.69677 \\ \mathrm{H} & -2.31297 & -0.89937 & -6.17888 \\ \mathrm{C} & -0.9594 & -0.38789 & -4.58434 \\ \mathrm{C} & 2.33603 & -2.25793 & -3.72258 \\ \mathrm{H} & 2.79117 & -1.37412 & -3.26517 \\ \mathrm{C} & 1.9913 & -3.2363 & -2.57069 \\ \mathrm{H} & 1.28732 & -2.7754 & -1.87079 \\ \mathrm{H} & 2.89965 & -3.51657 & -2.02279 \\ \mathrm{H} & 1.53244 & -4.15083 & -2.96614 \\ \mathrm{C} & 3.39828 & -2.86421 & -4.66252\end{array}$




\begin{tabular}{|c|c|c|c|}
\hline $\mathrm{H}$ & 3.08474 & -3.83569 & -5.0624 \\
\hline $\mathrm{H}$ & 4.32927 & -3.02932 & -4.10798 \\
\hline $\mathrm{H}$ & 3.61634 & -2.19992 & -5.50619 \\
\hline $\mathrm{C}$ & -1.87 & 0.72704 & -4.05671 \\
\hline $\mathrm{H}$ & -1.50224 & 1.0157 & -3.06742 \\
\hline $\mathrm{C}$ & -3.31297 & 0.20785 & -3.85948 \\
\hline $\mathrm{H}$ & -3.78448 & -0.06719 & -4.81033 \\
\hline $\mathrm{H}$ & -3.92803 & 0.98855 & -3.39771 \\
\hline $\mathrm{H}$ & -3.30233 & -0.66385 & -3.19811 \\
\hline $\mathrm{C}$ & -1.8702 & 1.97749 & -4.96786 \\
\hline $\mathrm{H}$ & -0.88269 & 2.44683 & -5.02803 \\
\hline $\mathrm{H}$ & -2.56808 & 2.7261 & -4.57424 \\
\hline $\mathrm{H}$ & -2.18996 & 1.72423 & -5.98656 \\
\hline $\mathrm{C}$ & 3.18112 & 2.14733 & -1.16791 \\
\hline $\mathrm{C}$ & 4.39303 & 1.51874 & -0.78391 \\
\hline $\mathrm{C}$ & 5.40149 & 2.33254 & -0.24855 \\
\hline $\mathrm{H}$ & 6.34189 & 1.88754 & 0.05568 \\
\hline $\mathrm{C}$ & 5.21749 & 3.71018 & -0.10327 \\
\hline $\mathrm{H}$ & 6.01376 & 4.32031 & 0.31195 \\
\hline $\mathrm{C}$ & 4.01511 & 4.30096 & -0.48582 \\
\hline $\mathrm{H}$ & 3.8798 & 5.37002 & -0.36246 \\
\hline $\mathrm{C}$ & 2.96373 & 3.53048 & -1.01047 \\
\hline $\mathrm{C}$ & 4.61901 & 0.0114 & -0.96138 \\
\hline $\mathrm{H}$ & 3.95237 & -0.32833 & -1.7621 \\
\hline $\mathrm{C}$ & 4.23137 & -0.78708 & 0.30587 \\
\hline $\mathrm{H}$ & 4.87773 & -0.51133 & 1.14716 \\
\hline $\mathrm{H}$ & 4.33963 & -1.86348 & 0.12408 \\
\hline $\mathrm{H}$ & 3.19541 & -0.57637 & 0.58537 \\
\hline $\mathrm{C}$ & 6.06002 & -0.33668 & -1.39519 \\
\hline $\mathrm{H}$ & 6.37456 & 0.23393 & -2.2768 \\
\hline $\mathrm{H}$ & 6.12349 & -1.40301 & -1.64064 \\
\hline $\mathrm{H}$ & 6.78217 & -0.1452 & -0.59312 \\
\hline $\mathrm{C}$ & 1.64097 & 4.19551 & -1.38939 \\
\hline $\mathrm{H}$ & 0.91416 & 3.40092 & -1.58693 \\
\hline $\mathrm{C}$ & 1.07264 & 5.0393 & -0.22648 \\
\hline $\mathrm{H}$ & 0.98159 & 4.4241 & 0.67434 \\
\hline $\mathrm{H}$ & 0.07939 & 5.42118 & -0.49149 \\
\hline $\mathrm{H}$ & 1.71034 & 5.90217 & 0.00123 \\
\hline $\mathrm{C}$ & 1.78918 & 5.04462 & -2.67444 \\
\hline $\mathrm{H}$ & 2.5035 & 5.86353 & -2.52299 \\
\hline $\mathrm{H}$ & 0.8245 & 5.48696 & -2.95124 \\
\hline $\mathrm{H}$ & 2.14346 & 4.44022 & -3.51659 \\
\hline $\mathrm{C}$ & 2.58344 & 1.34699 & -4.15023 \\
\hline $\mathrm{C}$ & 3.96819 & 1.62437 & -4.13128 \\
\hline $\mathrm{H}$ & 4.53235 & 1.52457 & -3.21772 \\
\hline $\mathrm{C}$ & 4.63491 & 2.03327 & -5.28871 \\
\hline
\end{tabular}




\begin{tabular}{|c|c|c|c|}
\hline $\mathrm{H}$ & 5.69975 & 2.23682 & -5.24217 \\
\hline $\mathrm{C}$ & 3.94346 & 2.17687 & -6.49529 \\
\hline $\mathrm{H}$ & 4.46427 & 2.49532 & -7.3924 \\
\hline $\mathrm{C}$ & 2.57188 & 1.90539 & -6.53137 \\
\hline $\mathrm{H}$ & 2.01713 & 2.01423 & -7.45749 \\
\hline $\mathrm{C}$ & 1.90066 & 1.49543 & -5.37818 \\
\hline $\mathrm{H}$ & 0.84273 & 1.29248 & -5.43535 \\
\hline $\mathrm{Ge}$ & 1.17449 & 1.23953 & 1.13056 \\
\hline $\mathrm{N}$ & -0.78377 & -0.07862 & 2.88908 \\
\hline $\mathrm{N}$ & -2.09752 & -1.31835 & 1.65552 \\
\hline $\mathrm{C}$ & -1.85482 & -0.92651 & 2.93739 \\
\hline $\mathrm{C}$ & -0.3077 & 0.06661 & 1.54184 \\
\hline $\mathrm{C}$ & -1.13195 & -0.76379 & 0.7534 \\
\hline $\mathrm{C}$ & -0.28297 & 0.71843 & 3.99441 \\
\hline $\mathrm{C}$ & -1.05986 & 1.81569 & 4.44338 \\
\hline $\mathrm{C}$ & -0.59016 & 2.53985 & 5.54936 \\
\hline $\mathrm{H}$ & -1.1643 & 3.38126 & 5.91856 \\
\hline $\mathrm{C}$ & 0.60459 & 2.19695 & 6.18278 \\
\hline $\mathrm{H}$ & 0.94426 & 2.76435 & 7.04382 \\
\hline $\mathrm{C}$ & 1.37211 & 1.14025 & 5.69677 \\
\hline $\mathrm{H}$ & 2.31297 & 0.89937 & 6.17888 \\
\hline $\mathrm{C}$ & 0.9594 & 0.38789 & 4.58434 \\
\hline $\mathrm{C}$ & -2.33603 & 2.25793 & 3.72258 \\
\hline $\mathrm{H}$ & -2.79117 & 1.37412 & 3.26517 \\
\hline $\mathrm{C}$ & -1.9913 & 3.2363 & 2.57069 \\
\hline $\mathrm{H}$ & -1.28732 & 2.7754 & 1.87079 \\
\hline $\mathrm{H}$ & -2.89965 & 3.51657 & 2.02279 \\
\hline $\mathrm{H}$ & -1.53244 & 4.15083 & 2.96614 \\
\hline $\mathrm{C}$ & -3.39828 & 2.86421 & 4.66252 \\
\hline $\mathrm{H}$ & -3.08474 & 3.83569 & 5.0624 \\
\hline $\mathrm{H}$ & -4.32927 & 3.02932 & 4.10798 \\
\hline $\mathrm{H}$ & -3.61634 & 2.19992 & 5.50619 \\
\hline $\mathrm{C}$ & 1.87 & -0.72704 & 4.05671 \\
\hline $\mathrm{H}$ & 1.50224 & -1.0157 & 3.06742 \\
\hline $\mathrm{C}$ & 3.31297 & -0.20785 & 3.85948 \\
\hline $\mathrm{H}$ & 3.78448 & 0.06719 & 4.81033 \\
\hline $\mathrm{H}$ & 3.92803 & -0.98855 & 3.39771 \\
\hline $\mathrm{H}$ & 3.30233 & 0.66385 & 3.19811 \\
\hline $\mathrm{C}$ & 1.8702 & -1.97749 & 4.96786 \\
\hline $\mathrm{H}$ & 0.88269 & -2.44683 & 5.02803 \\
\hline $\mathrm{H}$ & 2.56808 & -2.7261 & 4.57424 \\
\hline $\mathrm{H}$ & 2.18996 & -1.72423 & 5.98656 \\
\hline $\mathrm{C}$ & -3.18112 & -2.14733 & 1.16791 \\
\hline $\mathrm{C}$ & -4.39303 & -1.51874 & 0.78391 \\
\hline $\mathrm{C}$ & -5.40149 & -2.33254 & 0.24855 \\
\hline $\mathrm{H}$ & -6.34189 & -1.88754 & -0.05568 \\
\hline
\end{tabular}




\begin{tabular}{lrrr}
$\mathrm{C}$ & -5.21749 & -3.71018 & 0.10327 \\
$\mathrm{H}$ & -6.01376 & -4.32031 & -0.31195 \\
$\mathrm{C}$ & -4.01511 & -4.30096 & 0.48582 \\
$\mathrm{H}$ & -3.8798 & -5.37002 & 0.36246 \\
$\mathrm{C}$ & -2.96373 & -3.53048 & 1.01047 \\
$\mathrm{C}$ & -4.61901 & -0.0114 & 0.96138 \\
$\mathrm{H}$ & -3.95237 & 0.32833 & 1.7621 \\
$\mathrm{C}$ & -4.23137 & 0.78708 & -0.30587 \\
$\mathrm{H}$ & -4.87773 & 0.51133 & -1.14716 \\
$\mathrm{H}$ & -4.33963 & 1.86348 & -0.12408 \\
$\mathrm{H}$ & -3.19541 & 0.57637 & -0.58537 \\
$\mathrm{C}$ & -6.06002 & 0.33668 & 1.39519 \\
$\mathrm{H}$ & -6.37456 & -0.23393 & 2.2768 \\
$\mathrm{H}$ & -6.12349 & 1.40301 & 1.64064 \\
$\mathrm{H}$ & -6.78217 & 0.1452 & 0.59312 \\
$\mathrm{C}$ & -1.64097 & -4.19551 & 1.38939 \\
$\mathrm{H}$ & -0.91416 & -3.40092 & 1.58693 \\
$\mathrm{C}$ & -1.07264 & -5.0393 & 0.22648 \\
$\mathrm{H}$ & -0.98159 & -4.4241 & -0.67434 \\
$\mathrm{H}$ & -0.07939 & -5.42118 & 0.49149 \\
$\mathrm{H}$ & -1.71034 & -5.90217 & -0.00123 \\
$\mathrm{C}$ & -1.78918 & -5.04462 & 2.67444 \\
$\mathrm{H}$ & -2.5035 & -5.86353 & 2.52299 \\
$\mathrm{H}$ & -0.8245 & -5.48696 & 2.95124 \\
$\mathrm{H}$ & -2.14346 & -4.44022 & 3.51659 \\
$\mathrm{C}$ & -2.58344 & -1.34699 & 4.15023 \\
$\mathrm{C}$ & -3.96819 & -1.62437 & 4.13128 \\
$\mathrm{H}$ & -4.53235 & -1.52457 & 3.21772 \\
$\mathrm{C}$ & -4.63491 & -2.03327 & 5.28871 \\
$\mathrm{H}$ & -5.69975 & -2.23682 & 5.24217 \\
$\mathrm{C}$ & -3.94346 & -2.17687 & 6.49529 \\
$\mathrm{H}$ & -4.46427 & -2.49532 & 7.3924 \\
$\mathrm{C}$ & -2.57188 & -1.90539 & 6.53137 \\
$\mathrm{H}$ & -2.01713 & -2.01423 & 7.45749 \\
$\mathrm{C}$ & -1.90066 & -1.49543 & 5.37818 \\
$\mathrm{H}$ & -0.84273 & -1.29248 & 5.43535 \\
& & & \\
\hline
\end{tabular}

\section{Compound $\left[\left(\mathrm{ADC}^{\mathrm{Ph}}\right) \mathrm{Ge}\right]_{2}\left(4^{\mathrm{T}}\right)$}

$E_{\mathrm{UB} 3 L Y \mathrm{~L}(\mathrm{D} 3 \mathrm{BJ}) / 6-31 \mathrm{G}(\mathrm{d})}=-6930.141196 E_{\mathrm{H}}$

$\begin{array}{lrrr}\mathrm{Ge} & -1.18589 & -1.22251 & -1.13656 \\ \mathrm{~N} & 0.78242 & 0.09076 & -2.90259 \\ \mathrm{~N} & 2.10098 & 1.33965 & -1.66973 \\ \mathrm{C} & 1.87156 & 0.95208 & -2.98304 \\ \mathrm{C} & 0.32319 & -0.02909 & -1.57117\end{array}$




\begin{tabular}{|c|c|c|c|}
\hline $\mathrm{C}$ & 1.14772 & 0.77818 & -0.79301 \\
\hline $\mathrm{C}$ & 0.25205 & -0.74303 & -3.96456 \\
\hline $\mathrm{C}$ & 0.99362 & -1.87862 & -4.37307 \\
\hline $\mathrm{C}$ & 0.47463 & -2.65453 & -5.42031 \\
\hline $\mathrm{H}$ & 1.02146 & -3.52582 & -5.76056 \\
\hline $\mathrm{C}$ & -0.73503 & -2.32429 & -6.03263 \\
\hline $\mathrm{H}$ & -1.11401 & -2.93357 & -6.84732 \\
\hline $\mathrm{C}$ & -1.46573 & -1.22355 & -5.58737 \\
\hline $\mathrm{H}$ & -2.41573 & -0.99034 & -6.05464 \\
\hline $\mathrm{C}$ & -0.99985 & -0.41764 & -4.53575 \\
\hline $\mathrm{C}$ & 2.28962 & -2.29008 & -3.67083 \\
\hline $\mathrm{H}$ & 2.77292 & -1.37974 & -3.30177 \\
\hline $\mathrm{C}$ & 1.97919 & -3.17812 & -2.43902 \\
\hline $\mathrm{H}$ & 1.30498 & -2.66492 & -1.74589 \\
\hline $\mathrm{H}$ & 2.90391 & -3.4282 & -1.90431 \\
\hline $\mathrm{H}$ & 1.49825 & -4.11374 & -2.74934 \\
\hline $\mathrm{C}$ & 3.30469 & -2.98184 & -4.6035 \\
\hline $\mathrm{H}$ & 2.96078 & -3.97335 & -4.92113 \\
\hline $\mathrm{H}$ & 4.25413 & -3.12358 & -4.07447 \\
\hline $\mathrm{H}$ & 3.49974 & -2.38178 & -5.49901 \\
\hline $\mathrm{C}$ & -1.84276 & 0.76707 & -4.05475 \\
\hline $\mathrm{H}$ & -1.47021 & 1.05822 & -3.06772 \\
\hline $\mathrm{C}$ & -3.3241 & 0.36916 & -3.87018 \\
\hline $\mathrm{H}$ & -3.80784 & 0.12685 & -4.82365 \\
\hline $\mathrm{H}$ & -3.87916 & 1.20086 & -3.42117 \\
\hline $\mathrm{H}$ & -3.39674 & -0.49712 & -3.20507 \\
\hline $\mathrm{C}$ & -1.71622 & 1.98648 & -4.99849 \\
\hline $\mathrm{H}$ & -0.68161 & 2.33585 & -5.07685 \\
\hline $\mathrm{H}$ & -2.3265 & 2.81768 & -4.62522 \\
\hline $\mathrm{H}$ & -2.06776 & 1.73717 & -6.00764 \\
\hline $\mathrm{C}$ & 3.17546 & 2.15939 & -1.14844 \\
\hline $\mathrm{C}$ & 4.38912 & 1.52547 & -0.78162 \\
\hline $\mathrm{C}$ & 5.39152 & 2.32316 & -0.2119 \\
\hline $\mathrm{H}$ & 6.33349 & 1.87219 & 0.07834 \\
\hline $\mathrm{C}$ & 5.19881 & 3.69355 & -0.01686 \\
\hline $\mathrm{H}$ & 5.98973 & 4.29277 & 0.42355 \\
\hline $\mathrm{C}$ & 3.99474 & 4.29155 & -0.38414 \\
\hline $\mathrm{H}$ & 3.85401 & 5.35508 & -0.22429 \\
\hline $\mathrm{C}$ & 2.95114 & 3.53609 & -0.94452 \\
\hline $\mathrm{C}$ & 4.61405 & 0.02818 & -1.01714 \\
\hline $\mathrm{H}$ & 3.95756 & -0.2737 & -1.84072 \\
\hline $\mathrm{C}$ & 4.20778 & -0.81312 & 0.21688 \\
\hline $\mathrm{H}$ & 4.84543 & -0.57248 & 1.07548 \\
\hline $\mathrm{H}$ & 4.30972 & -1.88344 & $-2.3 \mathrm{E}-4$ \\
\hline $\mathrm{H}$ & 3.16975 & -0.61133 & 0.4984 \\
\hline $\mathrm{C}$ & 6.05749 & -0.30583 & -1.45071 \\
\hline
\end{tabular}




\begin{tabular}{|c|c|c|c|}
\hline $\mathrm{H}$ & 6.36935 & 0.29494 & -2.31223 \\
\hline $\mathrm{H}$ & 6.12349 & -1.36328 & -1.73162 \\
\hline $\mathrm{H}$ & 6.77628 & -0.14033 & -0.63965 \\
\hline $\mathrm{C}$ & 1.632 & 4.21078 & -1.3184 \\
\hline $\mathrm{H}$ & 0.91208 & 3.42246 & -1.56141 \\
\hline $\mathrm{C}$ & 1.04326 & 5.0128 & -0.13597 \\
\hline $\mathrm{H}$ & 0.94456 & 4.37215 & 0.74642 \\
\hline $\mathrm{H}$ & 0.05172 & 5.39877 & -0.40102 \\
\hline $\mathrm{H}$ & 1.67369 & 5.87078 & 0.12705 \\
\hline $\mathrm{C}$ & 1.79853 & 5.10465 & -2.57047 \\
\hline $\mathrm{H}$ & 2.50182 & 5.92393 & -2.37551 \\
\hline $\mathrm{H}$ & 0.83572 & 5.54767 & -2.85229 \\
\hline $\mathrm{H}$ & 2.17612 & 4.53123 & -3.42359 \\
\hline $\mathrm{C}$ & 2.58335 & 1.37263 & -4.18209 \\
\hline $\mathrm{C}$ & 3.88118 & 1.95603 & -4.12831 \\
\hline $\mathrm{H}$ & 4.38089 & 2.08933 & -3.18244 \\
\hline $\mathrm{C}$ & 4.54486 & 2.36142 & -5.28521 \\
\hline $\mathrm{H}$ & 5.53457 & 2.79889 & -5.19572 \\
\hline $\mathrm{C}$ & 3.95809 & 2.20584 & -6.54676 \\
\hline $\mathrm{H}$ & 4.48002 & 2.52148 & -7.44386 \\
\hline $\mathrm{C}$ & 2.68129 & 1.63597 & -6.62453 \\
\hline $\mathrm{H}$ & 2.19863 & 1.51115 & -7.58901 \\
\hline $\mathrm{C}$ & 2.00571 & 1.22906 & -5.47589 \\
\hline $\mathrm{H}$ & 1.01974 & 0.80713 & -5.58671 \\
\hline $\mathrm{Ge}$ & 1.18589 & 1.22251 & 1.13656 \\
\hline $\mathrm{N}$ & -0.78242 & -0.09076 & 2.90259 \\
\hline $\mathrm{N}$ & -2.10098 & -1.33965 & 1.66973 \\
\hline $\mathrm{C}$ & -1.87156 & -0.95208 & 2.98304 \\
\hline $\mathrm{C}$ & -0.32319 & 0.02909 & 1.57117 \\
\hline $\mathrm{C}$ & -1.14772 & -0.77818 & 0.79301 \\
\hline $\mathrm{C}$ & -0.25205 & 0.74303 & 3.96456 \\
\hline $\mathrm{C}$ & -0.99362 & 1.87862 & 4.37307 \\
\hline $\mathrm{C}$ & -0.47463 & 2.65453 & 5.42031 \\
\hline $\mathrm{H}$ & -1.02146 & 3.52582 & 5.76056 \\
\hline $\mathrm{C}$ & 0.73503 & 2.32429 & 6.03263 \\
\hline $\mathrm{H}$ & 1.11401 & 2.93357 & 6.84732 \\
\hline $\mathrm{C}$ & 1.46573 & 1.22355 & 5.58737 \\
\hline $\mathrm{H}$ & 2.41573 & 0.99034 & 6.05464 \\
\hline $\mathrm{C}$ & 0.99985 & 0.41764 & 4.53575 \\
\hline $\mathrm{C}$ & -2.28962 & 2.29008 & 3.67083 \\
\hline $\mathrm{H}$ & -2.77292 & 1.37974 & 3.30177 \\
\hline $\mathrm{C}$ & -1.97919 & 3.17812 & 2.43902 \\
\hline $\mathrm{H}$ & -1.30498 & 2.66492 & 1.74589 \\
\hline $\mathrm{H}$ & -2.90391 & 3.4282 & 1.90431 \\
\hline $\mathrm{H}$ & -1.49825 & 4.11374 & 2.74934 \\
\hline $\mathrm{C}$ & -3.30469 & 2.98184 & 4.6035 \\
\hline
\end{tabular}




\begin{tabular}{|c|c|c|c|}
\hline $\mathrm{H}$ & -2.96078 & 3.97335 & 4.92113 \\
\hline $\mathrm{H}$ & -4.25413 & 3.12358 & 4.07447 \\
\hline $\mathrm{H}$ & -3.49974 & 2.38178 & 5.49901 \\
\hline $\mathrm{C}$ & 1.84276 & -0.76707 & 4.05475 \\
\hline $\mathrm{H}$ & 1.47021 & -1.05822 & 3.06772 \\
\hline $\mathrm{C}$ & 3.3241 & -0.36916 & 3.87018 \\
\hline $\mathrm{H}$ & 3.80784 & -0.12685 & 4.82365 \\
\hline $\mathrm{H}$ & 3.87916 & -1.20086 & 3.42117 \\
\hline $\mathrm{H}$ & 3.39674 & 0.49712 & 3.20507 \\
\hline $\mathrm{C}$ & 1.71622 & -1.98648 & 4.99849 \\
\hline $\mathrm{H}$ & 0.68161 & -2.33585 & 5.07685 \\
\hline $\mathrm{H}$ & 2.3265 & -2.81768 & 4.62522 \\
\hline $\mathrm{H}$ & 2.06776 & -1.73717 & 6.00764 \\
\hline $\mathrm{C}$ & -3.17546 & -2.15939 & 1.14844 \\
\hline $\mathrm{C}$ & -4.38912 & -1.52547 & 0.78162 \\
\hline $\mathrm{C}$ & -5.39152 & -2.32316 & 0.2119 \\
\hline $\mathrm{H}$ & -6.33349 & -1.87219 & -0.07834 \\
\hline $\mathrm{C}$ & -5.19881 & -3.69355 & 0.01686 \\
\hline $\mathrm{H}$ & -5.98973 & -4.29277 & -0.42355 \\
\hline $\mathrm{C}$ & -3.99474 & -4.29155 & 0.38414 \\
\hline $\mathrm{H}$ & -3.85401 & -5.35508 & 0.22429 \\
\hline $\mathrm{C}$ & -2.95114 & -3.53609 & 0.94452 \\
\hline $\mathrm{C}$ & -4.61405 & -0.02818 & 1.01714 \\
\hline $\mathrm{H}$ & -3.95756 & 0.2737 & 1.84072 \\
\hline $\mathrm{C}$ & -4.20778 & 0.81312 & -0.21688 \\
\hline $\mathrm{H}$ & -4.84543 & 0.57248 & -1.07548 \\
\hline $\mathrm{H}$ & -4.30972 & 1.88344 & 2.3E-4 \\
\hline $\mathrm{H}$ & -3.16975 & 0.61133 & -0.4984 \\
\hline $\mathrm{C}$ & -6.05749 & 0.30583 & 1.45071 \\
\hline $\mathrm{H}$ & -6.36935 & -0.29494 & 2.31223 \\
\hline $\mathrm{H}$ & -6.12349 & 1.36328 & 1.73162 \\
\hline $\mathrm{H}$ & -6.77628 & 0.14033 & 0.63965 \\
\hline $\mathrm{C}$ & -1.632 & -4.21078 & 1.3184 \\
\hline $\mathrm{H}$ & -0.91208 & -3.42246 & 1.56141 \\
\hline $\mathrm{C}$ & -1.04326 & -5.0128 & 0.13597 \\
\hline $\mathrm{H}$ & -0.94456 & -4.37215 & -0.74642 \\
\hline $\mathrm{H}$ & -0.05172 & -5.39877 & 0.40102 \\
\hline $\mathrm{H}$ & -1.67369 & -5.87078 & -0.12705 \\
\hline $\mathrm{C}$ & -1.79853 & -5.10465 & 2.57047 \\
\hline $\mathrm{H}$ & -2.50182 & -5.92393 & 2.37551 \\
\hline $\mathrm{H}$ & -0.83572 & -5.54767 & 2.85229 \\
\hline $\mathrm{H}$ & -2.17612 & -4.53123 & 3.42359 \\
\hline $\mathrm{C}$ & -2.58335 & -1.37263 & 4.18209 \\
\hline $\mathrm{C}$ & -3.88118 & -1.95603 & 4.12831 \\
\hline $\mathrm{H}$ & -4.38089 & -2.08933 & 3.18244 \\
\hline $\mathrm{C}$ & -4.54486 & -2.36142 & 5.28521 \\
\hline
\end{tabular}




$\begin{array}{lrrr}\mathrm{H} & -5.53457 & -2.79889 & 5.19572 \\ \mathrm{C} & -3.95809 & -2.20584 & 6.54676 \\ \mathrm{H} & -4.48002 & -2.52148 & 7.44386 \\ \mathrm{C} & -2.68129 & -1.63597 & 6.62453 \\ \mathrm{H} & -2.19863 & -1.51115 & 7.58901 \\ \mathrm{C} & -2.00571 & -1.22906 & 5.47589 \\ \mathrm{H} & -1.01974 & -0.80713 & 5.58671 \\ \mathrm{Ge} & -1.18589 & -1.22251 & -1.13656 \\ \mathrm{~N} & 0.78242 & 0.09076 & -2.90259\end{array}$

\section{Compound $\left[\left(\mathrm{ADC}^{\mathrm{Ph}}\right) \mathrm{GeH}\right]_{2}(\mathbf{5})$}

$E_{\mathrm{B} 3 \mathrm{LYP}(\mathrm{D} 3 \mathrm{BJ}) / 6-31 \mathrm{G}(\mathrm{d})}=-6932.683721 E_{\mathrm{H}}$

$\begin{array}{lrrr}\mathrm{C} & -5.86439 & -0.99355 & -0.45371 \\ \mathrm{C} & -5.07683 & 0.09335 & -0.01485 \\ \mathrm{C} & -5.74754 & 1.19186 & 0.56547 \\ \mathrm{C} & -7.13173 & 1.19595 & 0.7015 \\ \mathrm{C} & -7.89421 & 0.10967 & 0.27251 \\ \mathrm{C} & -7.24732 & -0.98207 & -0.30648 \\ \mathrm{C} & -3.62171 & 0.06996 & -0.1432 \\ \mathrm{~N} & -2.81883 & -1.02727 & -0.27448 \\ \mathrm{C} & -1.47105 & -0.67282 & -0.32672 \\ \mathrm{C} & -1.43435 & 0.70416 & -0.25023 \\ \mathrm{~N} & -2.75608 & 1.12199 & -0.11538 \\ \mathrm{Ge} & -3.2032 & -2.41186 & -0.26346 \\ \mathrm{C} & -3.55405 & -2.99803 & 0.96521 \\ \mathrm{~N} & -3.85676 & -4.36194 & 0.9563 \\ \mathrm{C} & -3.79962 & -5.09953 & -0.2244 \\ \mathrm{~N} & -3.44053 & -4.48917 & -1.42229 \\ \mathrm{C} & -3.12752 & -3.1258 & -1.4718 \\ \mathrm{C} & -3.00701 & 2.51261 & 0.14376 \\ \mathrm{C} & -2.97761 & 2.93515 & 1.48435 \\ \mathrm{C} & -3.08383 & 4.30751 & 1.72212 \\ \mathrm{C} & -3.19368 & 5.20716 & 0.66301 \\ \mathrm{C} & -3.199 & 4.75471 & -0.65356 \\ \mathrm{C} & -3.09212 & 3.39028 & -0.94545 \\ \mathrm{C} & 6.49 \mathrm{E}-04 & -1.96332 & -0.67149 \\ \mathrm{C} & 1.37433 & -0.71528 & 0.04055 \\ \mathrm{C} & 2.68476 & -1.10769 & 0.31521 \\ \mathrm{C} & 3.52926 & -0.03529 & 0.37913 \\ \mathrm{C} & 2.72756 & 1.04288 & 0.14012 \\ \mathrm{C} & 1.40116 & 0.66326 & -0.04631 \\ \mathrm{Ge} & 3.11062 & 2.39921 & -0.14298 \\ \mathrm{C} & 3.37972 & 2.72723 & -1.48563 \\ \mathrm{C} & 3.74553 & 4.0493 & -1.75399\end{array}$




\begin{tabular}{|c|c|c|c|}
\hline $\mathrm{C}$ & 3.79824 & 4.99903 & -0.73607 \\
\hline $\mathrm{C}$ & 3.4549 & 4.65431 & 0.56864 \\
\hline $\mathrm{C}$ & 3.07813 & 3.34605 & 0.88894 \\
\hline $\mathrm{C}$ & 3.02695 & -2.50368 & 0.30132 \\
\hline $\mathrm{C}$ & 3.62036 & -3.03073 & -0.85712 \\
\hline $\mathrm{C}$ & 3.88456 & -4.40464 & -0.87148 \\
\hline $\mathrm{C}$ & 3.55945 & -5.20737 & 0.21593 \\
\hline $\mathrm{C}$ & 2.94726 & -4.65651 & 1.34058 \\
\hline $\mathrm{C}$ & 2.65026 & -3.29267 & 1.40396 \\
\hline $\mathrm{C}$ & 4.96314 & -0.05236 & 0.6614 \\
\hline $\mathrm{C}$ & 5.57776 & -1.18881 & 1.23256 \\
\hline $\mathrm{C}$ & 6.94376 & -1.21345 & 1.49204 \\
\hline $\mathrm{C}$ & 7.74573 & -0.10998 & 1.20057 \\
\hline $\mathrm{C}$ & 7.15367 & 1.02481 & 0.64724 \\
\hline $\mathrm{C}$ & 5.78897 & 1.05846 & 0.37936 \\
\hline $\mathrm{C}$ & 0.04566 & 1.95309 & -0.68291 \\
\hline $\mathrm{C}$ & 3.31154 & 1.6952 & -2.60527 \\
\hline $\mathrm{C}$ & 4.72063 & 1.32438 & -3.10052 \\
\hline $\mathrm{C}$ & 2.66457 & 2.9578 & 2.29877 \\
\hline $\mathrm{C}$ & 3.89575 & 2.72684 & 3.19211 \\
\hline $\mathrm{C}$ & 3.98516 & -2.16929 & -2.05732 \\
\hline $\mathrm{C}$ & 5.47228 & -2.31766 & -2.41862 \\
\hline $\mathrm{C}$ & 1.96169 & -2.67477 & 2.61586 \\
\hline $\mathrm{C}$ & 2.97588 & -2.04011 & 3.58474 \\
\hline $\mathrm{C}$ & -3.59882 & -2.17438 & 2.24662 \\
\hline $\mathrm{C}$ & -4.63157 & -2.68554 & 3.25856 \\
\hline $\mathrm{C}$ & -2.76952 & -2.44653 & -2.79067 \\
\hline $\mathrm{C}$ & -4.03441 & -1.94618 & -3.5134 \\
\hline $\mathrm{C}$ & -2.84291 & 1.93486 & 2.62657 \\
\hline $\mathrm{C}$ & -3.82377 & 2.21986 & 3.77346 \\
\hline $\mathrm{C}$ & -3.08256 & 2.86806 & -2.37513 \\
\hline $\mathrm{C}$ & -4.51909 & 2.60278 & -2.86181 \\
\hline $\mathrm{C}$ & 2.42575 & 2.16351 & -3.77142 \\
\hline $\mathrm{C}$ & 1.70592 & 3.98751 & 2.91399 \\
\hline $\mathrm{C}$ & 3.0719 & -2.4599 & -3.26051 \\
\hline $\mathrm{C}$ & 1.05736 & -3.67089 & 3.34993 \\
\hline $\mathrm{C}$ & -2.20271 & -2.06621 & 2.88575 \\
\hline $\mathrm{C}$ & -1.93308 & -3.34659 & -3.70987 \\
\hline $\mathrm{C}$ & -1.39347 & 1.85424 & 3.13721 \\
\hline $\mathrm{C}$ & -2.3269 & 3.79401 & -3.3368 \\
\hline $\mathrm{H}$ & 3.97736 & 4.34027 & -2.77381 \\
\hline $\mathrm{H}$ & 4.08713 & 6.02091 & -0.96605 \\
\hline $\mathrm{H}$ & 3.46334 & 5.41311 & 1.34427 \\
\hline $\mathrm{H}$ & 2.83954 & 0.79317 & -2.20716 \\
\hline $\mathrm{H}$ & 1.41146 & 2.37167 & -3.41896 \\
\hline $\mathrm{H}$ & 2.37394 & 1.37461 & -4.53073 \\
\hline
\end{tabular}




\begin{tabular}{|c|c|c|c|}
\hline $\mathrm{H}$ & 2.82681 & 3.06257 & -4.25378 \\
\hline $\mathrm{H}$ & 5.23071 & 2.20059 & -3.51807 \\
\hline $\mathrm{H}$ & 4.65595 & 0.56634 & -3.88916 \\
\hline $\mathrm{H}$ & 5.34457 & 0.92419 & -2.29589 \\
\hline $\mathrm{H}$ & 2.11498 & 2.01481 & 2.22633 \\
\hline $\mathrm{H}$ & 2.19805 & 4.94991 & 3.09606 \\
\hline $\mathrm{H}$ & 1.33397 & 3.62138 & 3.87731 \\
\hline $\mathrm{H}$ & 0.85124 & 4.14906 & 2.25027 \\
\hline $\mathrm{H}$ & 4.55276 & 1.95568 & 2.77819 \\
\hline $\mathrm{H}$ & 3.58724 & 2.41233 & 4.19591 \\
\hline $\mathrm{H}$ & 4.48211 & 3.64836 & 3.29143 \\
\hline $\mathrm{H}$ & 4.34185 & -4.84783 & -1.75067 \\
\hline $\mathrm{H}$ & 3.77239 & -6.27238 & 0.1855 \\
\hline $\mathrm{H}$ & 2.67981 & -5.30171 & 2.16956 \\
\hline $\mathrm{H}$ & 3.82596 & -1.12419 & -1.78896 \\
\hline $\mathrm{H}$ & 3.14349 & -3.50898 & -3.57094 \\
\hline $\mathrm{H}$ & 3.3661 & -1.83462 & -4.11234 \\
\hline $\mathrm{H}$ & 2.02659 & -2.24602 & -3.0143 \\
\hline $\mathrm{H}$ & 6.11132 & -2.09131 & -1.55894 \\
\hline $\mathrm{H}$ & 5.73276 & -1.62931 & -3.22951 \\
\hline $\mathrm{H}$ & 5.70569 & -3.33303 & -2.75846 \\
\hline $\mathrm{H}$ & 1.31302 & -1.878 & 2.24206 \\
\hline $\mathrm{H}$ & 0.35347 & -4.13444 & 2.652 \\
\hline $\mathrm{H}$ & 0.48154 & -3.14656 & 4.11953 \\
\hline $\mathrm{H}$ & 1.62975 & -4.45998 & 3.85193 \\
\hline $\mathrm{H}$ & 3.68845 & -2.78815 & 3.95327 \\
\hline $\mathrm{H}$ & 2.4545 & -1.61487 & 4.45003 \\
\hline $\mathrm{H}$ & 3.54584 & -1.23535 & 3.11164 \\
\hline $\mathrm{H}$ & 4.99073 & -2.06028 & 1.47798 \\
\hline $\mathrm{H}$ & 7.37922 & -2.10608 & 1.93172 \\
\hline $\mathrm{H}$ & 8.81219 & -0.13333 & 1.40353 \\
\hline $\mathrm{H}$ & 7.75615 & 1.89758 & 0.41277 \\
\hline $\mathrm{H}$ & 5.3709 & 1.95241 & -0.05658 \\
\hline $\mathrm{H}$ & -4.1386 & -4.85477 & 1.88018 \\
\hline $\mathrm{H}$ & -4.03519 & -6.16012 & -0.209 \\
\hline $\mathrm{H}$ & -3.39651 & -5.07936 & -2.33097 \\
\hline $\mathrm{H}$ & -3.91187 & -1.16262 & 1.9769 \\
\hline $\mathrm{H}$ & -1.46392 & -1.69417 & 2.1722 \\
\hline $\mathrm{H}$ & -2.23283 & -1.391 & 3.74964 \\
\hline $\mathrm{H}$ & -1.86528 & -3.04924 & 3.23069 \\
\hline $\mathrm{H}$ & -4.34629 & -3.65457 & 3.68376 \\
\hline $\mathrm{H}$ & -4.71238 & -1.97791 & 4.09088 \\
\hline $\mathrm{H}$ & -5.62132 & -2.78836 & 2.80076 \\
\hline $\mathrm{H}$ & -2.15103 & -1.57396 & -2.56878 \\
\hline $\mathrm{H}$ & -2.51185 & -4.19143 & -4.10225 \\
\hline $\mathrm{H}$ & -1.58286 & -2.76433 & -4.56912 \\
\hline
\end{tabular}




\begin{tabular}{rrrr}
$\mathrm{H}$ & -1.05607 & -3.72923 & -3.1798 \\
$\mathrm{H}$ & -4.57361 & -1.20017 & -2.92134 \\
$\mathrm{H}$ & -3.76333 & -1.48159 & -4.46837 \\
$\mathrm{H}$ & -4.72243 & -2.77427 & -3.72319 \\
$\mathrm{H}$ & -3.06919 & 4.67777 & 2.74224 \\
$\mathrm{H}$ & -3.26781 & 6.27187 & 0.86663 \\
$\mathrm{H}$ & -3.27008 & 5.47061 & -1.46522 \\
$\mathrm{H}$ & -3.09451 & 0.94599 & 2.23382 \\
$\mathrm{H}$ & -1.07579 & 2.81578 & 3.5559 \\
$\mathrm{H}$ & -1.3126 & 1.09319 & 3.92227 \\
$\mathrm{H}$ & -0.71215 & 1.59834 & 2.32317 \\
$\mathrm{H}$ & -4.85718 & 2.2727 & 3.41401 \\
$\mathrm{H}$ & -3.76476 & 1.41993 & 4.52006 \\
$\mathrm{H}$ & -3.5928 & 3.16117 & 4.28442 \\
$\mathrm{H}$ & -2.54376 & 1.91533 & -2.37448 \\
$\mathrm{H}$ & -1.3197 & 3.99713 & -2.9599 \\
$\mathrm{H}$ & -2.2356 & 3.31181 & -4.31628 \\
$\mathrm{H}$ & -2.84833 & 4.74647 & -3.48961 \\
$\mathrm{H}$ & -5.09897 & 3.5334 & -2.88559 \\
$\mathrm{H}$ & -4.50789 & 2.18388 & -3.87475 \\
$\mathrm{H}$ & -5.04282 & 1.89947 & -2.20705 \\
$\mathrm{H}$ & -5.19028 & 2.0485 & 0.91191 \\
$\mathrm{H}$ & -7.61338 & 2.05828 & 1.15352 \\
$\mathrm{H}$ & -8.97434 & 0.11528 & 0.38408 \\
$\mathrm{H}$ & -7.82076 & -1.8352 & -0.65732 \\
$\mathrm{H}$ & -5.39966 & -1.85099 & -0.9157 \\
$\mathrm{H}$ & -0.01317 & 2.87566 & 0.62252 \\
$\mathrm{H}$ & -0.24175 & -2.8808 & 0.62121 \\
& & & \\
\hline & & & \\
& & &
\end{tabular}

\section{Compound $\left[\left(\mathrm{ADC}^{\mathrm{Ph}}\right) \mathrm{GeH}\right]_{2}{ }^{\mathbf{t}}\left(\mathbf{H}_{\mathbf{2}} \mathbf{4}^{\mathrm{l}}\right)$}

$E_{\mathrm{B} 3 \mathrm{LYP}(\mathrm{D} 3 \mathrm{BJ}) / 6-31 \mathrm{G}(\mathrm{d})}=--6932.681152 E_{\mathrm{H}}$

$\begin{array}{lrrr}\mathrm{C} & 3.2937 & -3.15886 & -1.23749 \\ \mathrm{C} & 3.296 & -2.36044 & -0.08306 \\ \mathrm{C} & 3.67058 & -2.83946 & 1.18596 \\ \mathrm{C} & 4.11198 & -4.16228 & 1.26468 \\ \mathrm{C} & 4.16404 & -4.96909 & 0.12927 \\ \mathrm{C} & 3.75212 & -4.47488 & -1.10338 \\ \mathrm{~N} & 2.85826 & -0.99363 & -0.18415 \\ \mathrm{C} & 3.6403 & 0.11011 & -0.0228 \\ \mathrm{~N} & 2.77304 & 1.15591 & -0.01391 \\ \mathrm{C} & 1.45934 & 0.72816 & -0.22925 \\ \mathrm{C} & 1.51106 & -0.6419 & -0.32188 \\ \mathrm{C} & 5.10169 & 0.14696 & 0.08233 \\ \mathrm{C} & 5.88542 & -0.8686 & -0.50297\end{array}$




\begin{tabular}{|c|c|c|c|}
\hline $\mathrm{C}$ & 7.27276 & -0.84532 & -0.41018 \\
\hline $\mathrm{C}$ & 7.92192 & 0.18932 & 0.26375 \\
\hline $\mathrm{C}$ & 7.16089 & 1.20325 & 0.84339 \\
\hline $\mathrm{C}$ & 5.77154 & 1.18504 & 0.75981 \\
\hline $\mathrm{C}$ & 3.07726 & 2.5544 & 0.12199 \\
\hline $\mathrm{C}$ & 3.11988 & 3.09888 & 1.41721 \\
\hline $\mathrm{C}$ & 3.35372 & 4.47176 & 1.52277 \\
\hline $\mathrm{C}$ & 3.52133 & 5.25761 & 0.38265 \\
\hline $\mathrm{C}$ & 3.43691 & 4.69076 & -0.88436 \\
\hline $\mathrm{C}$ & 3.18899 & 3.32273 & -1.04307 \\
\hline $\mathrm{Ge}$ & -0.01547 & 2.04329 & -0.64729 \\
\hline $\mathrm{C}$ & -1.437 & 0.69818 & -0.16419 \\
\hline $\mathrm{N}$ & -2.78557 & 1.02664 & 0.02213 \\
\hline $\mathrm{C}$ & -3.54582 & -0.09234 & 0.18368 \\
\hline $\mathrm{N}$ & -2.66556 & -1.12617 & 0.12497 \\
\hline $\mathrm{C}$ & -1.36851 & -0.67422 & -0.11538 \\
\hline $\mathrm{Ge}$ & 0.05049 & -1.97645 & -0.67079 \\
\hline $\mathrm{C}$ & -3.28188 & 2.37771 & 0.03075 \\
\hline $\mathrm{C}$ & -3.35389 & 3.07057 & -1.18805 \\
\hline $\mathrm{C}$ & -3.91274 & 4.3546 & -1.15871 \\
\hline $\mathrm{C}$ & -4.35518 & 4.91954 & 0.03177 \\
\hline $\mathrm{C}$ & -4.23784 & 4.21687 & 1.2302 \\
\hline $\mathrm{C}$ & -3.69669 & 2.93023 & 1.25633 \\
\hline $\mathrm{C}$ & -4.99983 & -0.16875 & 0.36133 \\
\hline $\mathrm{C}$ & -5.85235 & 0.82677 & -0.15867 \\
\hline $\mathrm{C}$ & -7.23174 & 0.74159 & 0.00153 \\
\hline $\mathrm{C}$ & -7.80408 & -0.33417 & 0.68018 \\
\hline $\mathrm{C}$ & -6.97411 & -1.32768 & 1.19757 \\
\hline $\mathrm{C}$ & -5.59326 & -1.24887 & 1.0447 \\
\hline $\mathrm{C}$ & -3.00758 & -2.52164 & 0.11191 \\
\hline $\mathrm{C}$ & -3.47037 & -3.07251 & -1.08902 \\
\hline $\mathrm{C}$ & -3.92243 & -4.39589 & -1.0528 \\
\hline $\mathrm{C}$ & -3.86155 & -5.1371 & 0.1235 \\
\hline $\mathrm{C}$ & -3.29126 & -4.58916 & 1.27244 \\
\hline $\mathrm{C}$ & -2.82582 & -3.27181 & 1.28432 \\
\hline $\mathrm{C}$ & -2.92252 & 2.45518 & -2.51464 \\
\hline $\mathrm{C}$ & -4.15565 & 2.00085 & -3.31924 \\
\hline $\mathrm{C}$ & -3.50299 & 2.16644 & 2.55829 \\
\hline $\mathrm{C}$ & -4.47328 & 2.57723 & 3.67045 \\
\hline $\mathrm{C}$ & -3.42287 & -2.28833 & -2.39145 \\
\hline $\mathrm{C}$ & -4.82799 & -1.9495 & -2.91022 \\
\hline $\mathrm{C}$ & -2.1153 & -2.68552 & 2.49715 \\
\hline $\mathrm{C}$ & -3.09356 & -2.24759 & 3.59958 \\
\hline $\mathrm{C}$ & 2.91575 & 2.21498 & 2.64296 \\
\hline $\mathrm{C}$ & 3.60726 & 2.7533 & 3.90142 \\
\hline $\mathrm{C}$ & 3.02 & 2.69629 & -2.4198 \\
\hline
\end{tabular}




\begin{tabular}{|c|c|c|c|}
\hline $\mathrm{C}$ & 4.38352 & 2.35961 & -3.04508 \\
\hline $\mathrm{C}$ & 3.54481 & -1.96037 & 2.42453 \\
\hline $\mathrm{C}$ & 4.46155 & -2.38415 & 3.57744 \\
\hline $\mathrm{C}$ & 2.82749 & -2.63805 & -2.59262 \\
\hline $\mathrm{C}$ & 4.01529 & -2.25284 & -3.49166 \\
\hline $\mathrm{C}$ & -2.0227 & 3.40686 & -3.34743 \\
\hline $\mathrm{C}$ & -2.03745 & 2.29889 & 3.00874 \\
\hline $\mathrm{C}$ & -2.59118 & -3.05306 & -3.43518 \\
\hline $\mathrm{C}$ & -1.06368 & -3.66571 & 3.03785 \\
\hline $\mathrm{C}$ & 2.07661 & -1.89698 & 2.88842 \\
\hline $\mathrm{C}$ & 1.90639 & -3.64804 & -3.29683 \\
\hline $\mathrm{C}$ & 1.41948 & 1.96686 & 2.90358 \\
\hline $\mathrm{C}$ & 2.16154 & 3.57596 & -3.34004 \\
\hline $\mathrm{H}$ & 4.41725 & -4.57026 & 2.22161 \\
\hline $\mathrm{H}$ & 4.51541 & -5.99392 & 0.21162 \\
\hline $\mathrm{H}$ & 3.77404 & -5.12033 & -1.97527 \\
\hline $\mathrm{H}$ & 3.84724 & -0.94656 & 2.14943 \\
\hline $\mathrm{H}$ & 1.40717 & -1.58563 & 2.0823 \\
\hline $\mathrm{H}$ & 1.96861 & -1.189 & 3.71877 \\
\hline $\mathrm{H}$ & 1.75065 & -2.88333 & 3.23289 \\
\hline $\mathrm{H}$ & 4.16117 & -3.34667 & 4.00711 \\
\hline $\mathrm{H}$ & 4.41022 & -1.64085 & 4.38041 \\
\hline $\mathrm{H}$ & 5.50451 & -2.46315 & 3.25227 \\
\hline $\mathrm{H}$ & 2.23352 & -1.7364 & -2.43064 \\
\hline $\mathrm{H}$ & 2.45894 & -4.52169 & -3.66301 \\
\hline $\mathrm{H}$ & 1.42843 & -3.17086 & -4.15864 \\
\hline $\mathrm{H}$ & 1.12152 & -3.99069 & -2.61582 \\
\hline $\mathrm{H}$ & 4.60541 & -1.43838 & -3.0587 \\
\hline $\mathrm{H}$ & 3.6533 & -1.91727 & -4.4701 \\
\hline $\mathrm{H}$ & 4.68314 & -3.1079 & -3.65298 \\
\hline $\mathrm{H}$ & 3.40542 & 4.93546 & 2.50161 \\
\hline $\mathrm{H}$ & 3.70494 & 6.32343 & 0.48658 \\
\hline $\mathrm{H}$ & 3.53969 & 5.31966 & -1.76247 \\
\hline $\mathrm{H}$ & 3.36792 & 1.24044 & 2.42515 \\
\hline $\mathrm{H}$ & 0.89435 & 2.91487 & 3.05868 \\
\hline $\mathrm{H}$ & 1.28563 & 1.34629 & 3.79728 \\
\hline $\mathrm{H}$ & 0.95546 & 1.45617 & 2.05883 \\
\hline $\mathrm{H}$ & 4.66628 & 2.97075 & 3.72232 \\
\hline $\mathrm{H}$ & 3.54326 & 2.01084 & 4.70402 \\
\hline $\mathrm{H}$ & 3.12954 & 3.66899 & 4.26761 \\
\hline $\mathrm{H}$ & 2.46138 & 1.76509 & -2.29479 \\
\hline $\mathrm{H}$ & 1.22754 & 3.84156 & -2.83605 \\
\hline $\mathrm{H}$ & 1.91567 & 3.02518 & -4.25427 \\
\hline $\mathrm{H}$ & 2.67578 & 4.49797 & -3.63569 \\
\hline $\mathrm{H}$ & 4.97648 & 3.26886 & -3.20179 \\
\hline $\mathrm{H}$ & 4.24887 & 1.87038 & -4.01671 \\
\hline
\end{tabular}




\begin{tabular}{|c|c|c|c|}
\hline $\mathrm{H}$ & 4.96318 & 1.68912 & -2.40169 \\
\hline $\mathrm{H}$ & 5.2144 & 1.98692 & 1.21852 \\
\hline $\mathrm{H}$ & 7.64657 & 2.01799 & 1.37256 \\
\hline $\mathrm{H}$ & 9.00555 & 0.2057 & 0.33397 \\
\hline $\mathrm{H}$ & 7.84649 & -1.64163 & -0.87518 \\
\hline $\mathrm{H}$ & 5.412 & -1.67986 & -1.03444 \\
\hline $\mathrm{H}$ & -4.00028 & 4.91345 & -2.08549 \\
\hline $\mathrm{H}$ & -4.78817 & 5.91605 & 0.03051 \\
\hline $\mathrm{H}$ & -4.57447 & 4.67612 & 2.15284 \\
\hline $\mathrm{H}$ & -2.33188 & 1.56321 & -2.29948 \\
\hline $\mathrm{H}$ & -1.99785 & 4.42024 & -2.93854 \\
\hline $\mathrm{H}$ & -0.99601 & 3.03618 & -3.35288 \\
\hline $\mathrm{H}$ & -2.37022 & 3.4729 & -4.38445 \\
\hline $\mathrm{H}$ & -4.80673 & 2.84953 & -3.56165 \\
\hline $\mathrm{H}$ & -3.83818 & 1.53824 & -4.26046 \\
\hline $\mathrm{H}$ & -4.7502 & 1.26366 & -2.77031 \\
\hline $\mathrm{H}$ & -3.6876 & 1.10672 & 2.35889 \\
\hline $\mathrm{H}$ & -1.81414 & 3.33564 & 3.28642 \\
\hline $\mathrm{H}$ & -1.83459 & 1.65767 & 3.87443 \\
\hline $\mathrm{H}$ & -1.36051 & 2.01959 & 2.19958 \\
\hline $\mathrm{H}$ & -5.51436 & 2.51534 & 3.33534 \\
\hline $\mathrm{H}$ & -4.35145 & 1.91011 & 4.53061 \\
\hline $\mathrm{H}$ & -4.28517 & 3.59791 & 4.0227 \\
\hline $\mathrm{H}$ & -4.30844 & -4.8523 & -1.95925 \\
\hline $\mathrm{H}$ & -4.22475 & -6.161 & 0.1375 \\
\hline $\mathrm{H}$ & -3.19132 & -5.20036 & 2.16369 \\
\hline $\mathrm{H}$ & -2.88347 & -1.3559 & -2.20298 \\
\hline $\mathrm{H}$ & -3.07535 & -3.98952 & -3.73558 \\
\hline $\mathrm{H}$ & -2.45694 & -2.43858 & -4.33231 \\
\hline $\mathrm{H}$ & -1.60415 & -3.28524 & -3.02577 \\
\hline $\mathrm{H}$ & -5.40131 & -1.38144 & -2.17113 \\
\hline $\mathrm{H}$ & -4.76337 & -1.35278 & -3.82718 \\
\hline $\mathrm{H}$ & -5.39046 & -2.86204 & -3.14167 \\
\hline $\mathrm{H}$ & -1.57096 & -1.79977 & 2.15763 \\
\hline $\mathrm{H}$ & -0.36949 & -3.94892 & 2.2403 \\
\hline $\mathrm{H}$ & -0.49418 & -3.19263 & 3.84465 \\
\hline $\mathrm{H}$ & -1.51925 & -4.57513 & 3.44593 \\
\hline $\mathrm{H}$ & -3.6989 & -3.09332 & 3.94797 \\
\hline $\mathrm{H}$ & -2.54281 & -1.85006 & 4.45987 \\
\hline $\mathrm{H}$ & -3.77658 & -1.46633 & 3.25025 \\
\hline $\mathrm{H}$ & -4.98002 & -2.03583 & 1.45532 \\
\hline $\mathrm{H}$ & -7.39817 & -2.17416 & 1.72972 \\
\hline $\mathrm{H}$ & -8.88138 & -0.3978 & 0.80195 \\
\hline $\mathrm{H}$ & -7.85991 & 1.52314 & -0.4157 \\
\hline $\mathrm{H}$ & -5.4437 & 1.66774 & -0.697 \\
\hline $\mathrm{H}$ & -0.08651 & -1.34711 & -2.19896 \\
\hline
\end{tabular}


$\mathbf{H}_{2}$

$E_{\mathrm{B} 3 \mathrm{LYP}(\mathrm{D} 3 \mathrm{BJ}) / 6-31 \mathrm{G}(\mathrm{d})}=-1.175623 E_{\mathrm{H}}$

$\begin{array}{llll}\mathrm{H} & 0.0 & 0.0 & 0.37142 \\ \mathrm{H} & 0.0 & 0.0 & -0.37142\end{array}$

$\mathrm{H}$

$\begin{array}{lll}0.0 & 0.0 & -0.37142\end{array}$ 


\section{References}

1. N. K. T. Ho, B. Neumann, H.-G. Stammler, V. H. Menezes da Silva, D. G. Watanabe, A. A. C. Braga, R. S. Ghadwal, Dalton Trans., 2017, 46, 12027-12031.

2. A. K. Swarnakar, S. M. McDonald, K. C. Deutsch, P. Choi, M. J. Ferguson, R. McDonald, E. Rivard, Inorg. Chem. 2014, 53, 8662-8671.

3. G. R. Fulmer, A. J. M. Miller, N. H. Sherden, H. E. Gottlieb, A. Nudelman, B. M. Stoltz, J. E. Bercaw, K. I. Goldberg, Organometallics 2010, 29, 2176-2179.

4. D. Rottschäfer, F. Ebeler, T. Strothmann, B. Neumann, H.-G. Stammler, A. Mix, R. S. Ghadwal, Chem. - Eur. J. 2018, 24, 3716-3720.

5. O. V. Dolomanov, L. J. Bourhis, R. J. Gildea, J. A. K. Howard, H. Puschmann, OLEX2: a complete structure solution, refinement and analysis program, J. Appl. Cryst. 2009, 42, 339-341.

6. G. M. Sheldrick, A short history of SHELX, Acta Cryst. 2008, A64, 112-122.

7. G. M. Sheldrick, Crystal structure refinement with SHELXL, Acta Cryst. 2015, C71, 3-8.

8. Gaussian 16, Revision B.01, M. J. Frisch, G. W. Trucks, H. B. Schlegel, G. E. Scuseria, M. A. Robb, J. R. Cheeseman, G. Scalmani, V. Barone, G. A. Petersson, H. Nakatsuji, X. Li, M. Caricato, A. V. Marenich, J. Bloino, B. G. Janesko, R. Gomperts, B. Mennucci, H. P. Hratchian, J. V. Ortiz, A. F. Izmaylov, J. L. Sonnenberg, D. Williams-Young, F. Ding, F. Lipparini, F. Egidi, J. Goings, B. Peng, A. Petrone, T. Henderson, D. Ranasinghe, V. G. Zakrzewski, J. Gao, N. Rega, G. Zheng, W. Liang, M. Hada, M. Ehara, K. Toyota, R. Fukuda, J. Hasegawa, M. Ishida, T. Nakajima, Y. Honda, O. Kitao, H. Nakai, T. Vreven, K. Throssell, J. A. Montgomery, Jr., J. E. Peralta, F. Ogliaro, M. J. Bearpark, J. J. Heyd, E. N. Brothers, K. N. Kudin, V. N. Staroverov, T. A. Keith, R. Kobayashi, J. Normand, K. Raghavachari, A. P. Rendell, J. C. Burant, S. S. Iyengar, J. Tomasi, M. Cossi, J. M. Millam, M. Klene, C. Adamo, R. Cammi, J. W. Ochterski, R. L. Martin, K. Morokuma, O. Farkas, J. B. Foresman, D. J. Fox, Gaussian, Inc., Wallingford CT, 2016.

9. (a) A. D. Becke, J. Chem. Phys., 1993, 98, 5648-5652; (b) S. H. Vosko, L. Wilk, and M. Nusair, Can. J. Phys., 1980, 58, 1200-1211; (c) C. Lee, W. Yang, and R. G. Parr, Phys. Rev. B, 1988, 37, 785-789; (d) P.J. Stephens, F.J. Devlin, C.F. Chabalowski, and M.J. Frisch, J. Phys. Chem., 1994, 98, 11623-11627.

10. R. Ditchfield, W. J. Hehre, and J. A. Pople J. Chem. Phys., 1971, 54, 724-728.

11. (a) A. E. Reed and F. Weinhold, J. Chem. Phys. 1985, 83, 1736-1740; (b) A. E. Reed, R. B. Weinstock, and F. Weinhold, J. Chem. Phys. 1985, 83, 735-746; (c) E. D. Glendening, A. E. Reed, J. E. Carpenter, and F. Weinhold, NBO Version 3.1. 
12. Z. Chen, C. S. Wannere, C. Corminboeuf, R. Puchta, P. von Ragué Schleyer, Chem. Rev. 2005, 105, 3842-3888; b) C. Corminboeuf, T. Heine, G. Seifert, P. Von Ragué Schleyer, J. Weber, Phys. Chem. Chem. Phys. 2004, 6, 273-276.

13. K. B. Wiberg, Tetrahedron 1968, 24, 1083-1096.

14. F. Neese, WIREs Comput Mol Sci, 2012, 2, 73-78.

15. F. Neese, F. Wennmohs, A. Hansen, U. Becker, Chem. Phys., 2009, 356, 98-109.

16. Y. Guo, F. Neese, J. Chem. Phys. 2016, 144, 094111.

17. V. Barone, M. Cossi, J. Phys. Chem. A 1998, 102, 1995-2001.

18. F. Neese, J. Comp. Chem. 2003, 24, 1740-1747

19. a) M. Nakano, R. Kishi, T. Nitta T. Kubo, K. Nakasuji, K. Kamada, K. Ohta, B. Champagne E. Botek. K. Yamaguchi, J. Phys. Chem. A 2005, 109, 5, 885-891; b) P. Ravat, M. Baumgarten Phys. Chem. Chem. Phys. 2015, 17, 983-991

20. S. Grimme, Chem Eur. J., 2012, 18, 9955-9964.

21. F. Weigend, R. Ahlrichs, Phys. Chem. Chem. Phys., 2005,7, 3297-3305.

22. A) S. Grimme, J. Antony, S. Ehrlich, and H. Krieg, J. Chem. Phys, 2010, 132, 154104; b) S. Grimme, S. Ehrlich,L. Goerigk, J. Comput. Chem, 2011, 32, 1456-1465.

23. a) J. R. Cheeseman, G. W. Trucks, T. A. Keith, M. J. Frisch, J. Chem. Phys. 1996, 104, 5497-5509; b) J. Gauss, Chem. Phys. Lett. 1992, 191, 614-620; c) J. Gauss, J. Chem. Phys. 1993, 99, 3629-3643; d) J. Gauss, Ber. Bunsenges. Phys. Chem. 1995, 99, 10011008.

24. a) S. Miertuš, E. Scrocco, J. Tomasi, Chem. Phys. 1981, 55, 117-129; b) S. Miertus̃, J. Tomasi, Chem. Phys. 1982, 65, 239-245; c) J. L. Pascual-ahuir, E. Silla, I. Tuñon, J. Comput. Chem. 1994, 15, 1127-1138.

25. a) G. Scalmani, M. J. Frisch, B. Mennucci, J. Tomasi, R. Cammi, V. Barone, J. Chem. Phys. 2006, 124, 94107; b) R. E. Stratmann, G. E. Scuseria, M. J. Frisch, J. Chem. Phys. 1998, 109, 8218-8224; c) C. van Caillie, R. D. Amos, Chem. Phys. Lett. 1999, 308, 249255; d) C. van Caillie, R. D. Amos, Chem. Phys. Lett. 2000, 317, 159-164; e) R. Bauernschmitt, R. Ahlrichs, Chem. Phys. Lett. 1996, 256, 454-464; f) M. E. Casida, C. Jamorski, K. C. Casida, D. R. Salahub, J. Chem. Phys. 1998, 108, 4439-4449. 